\title{
Essays on Foreign Direct Investment and Development Economics
}

by

\author{
Ilkin Huseynov \\ A thesis submitted to Victoria University of Wellington \\ in fulfilment of the requirements for the degree of \\ Doctor of Philosophy in Economics
}

Victoria University of Wellington

2019 


\section{Contents}

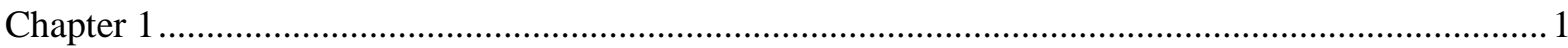

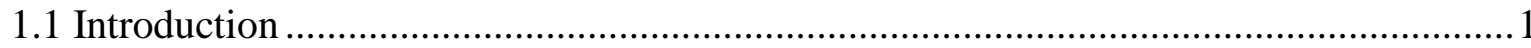

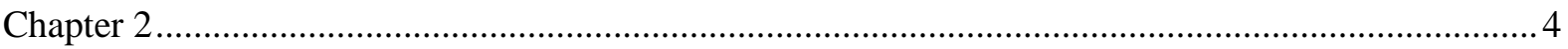

Globalizing Chinese Infrastructure Investment: The Role of Host-Country Geography, Institutions, and Macroeconomic Stability....................................................................

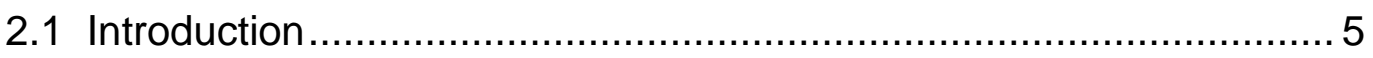

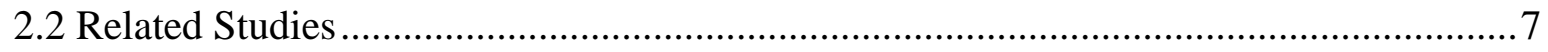

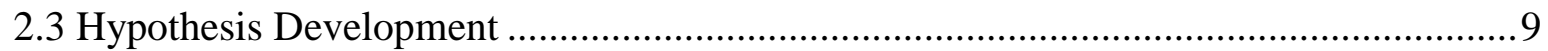

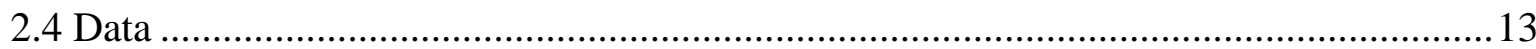

2.4.1 Descriptive overview of Chinese outward infrastructure FDI ........ 13

2.4.2 Variables description: ...................................................... 16

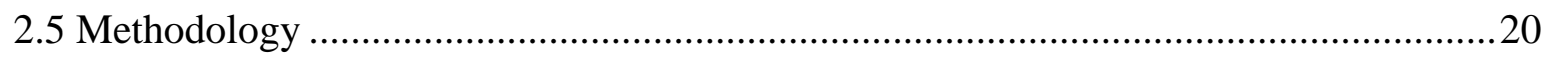

2.5.1 Theoretical Background and Log of Gravity Model ...................... 20

2.5.2 Empirical Specification....................................................... 22

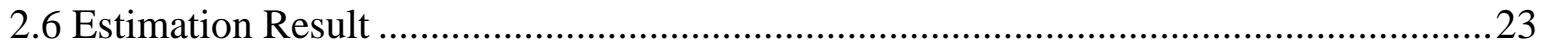

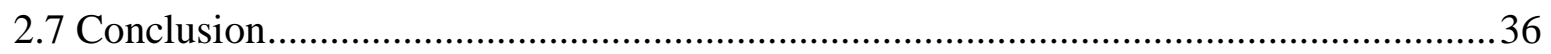

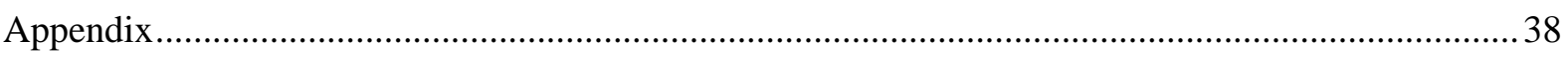

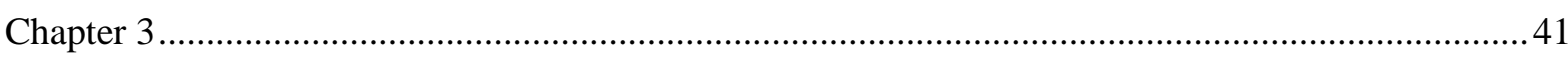

Why Do SMEs Not Borrow More from Banks? Evidence from Developing Asia ............41

3.1 Introduction ................................................................... 42

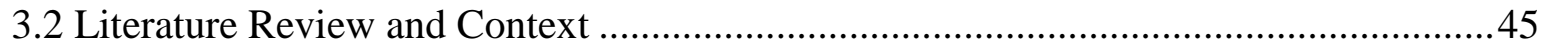

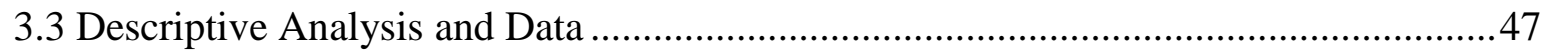

3.3.1 SMEs and Bank Borrowing ............................................ 47

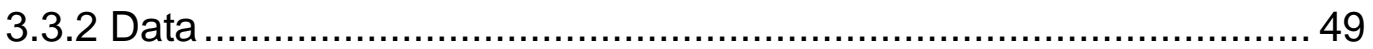

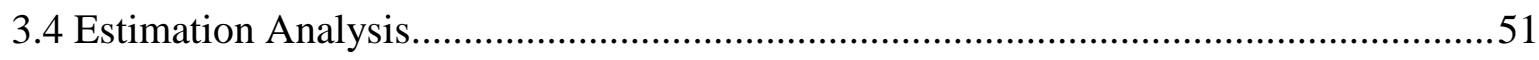

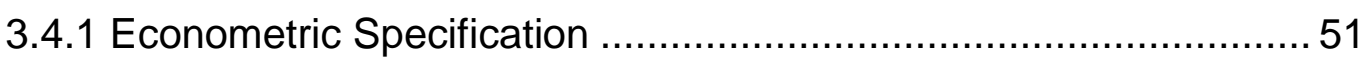

3.4.2 Estimation Results ................................................... 53

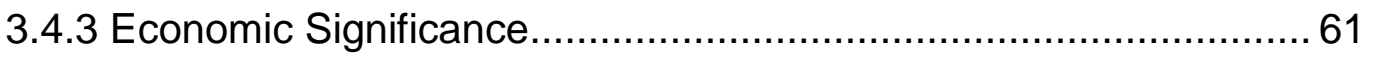

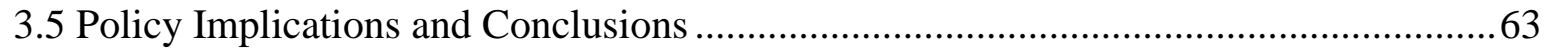

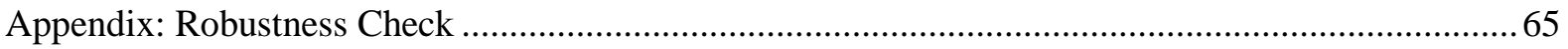

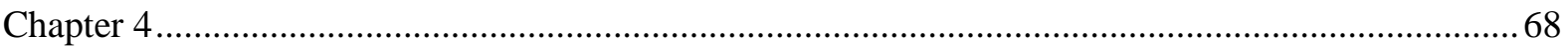


Role of Infrastructure Investment Deals as a Signalling on FDI. Case of Developing Countries.

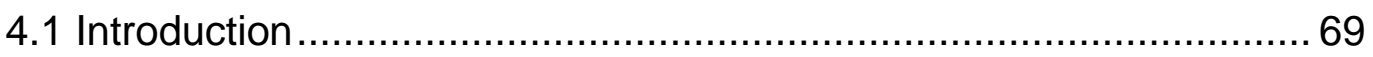

4.2 Literature Review on Infrastructure Endowment and FDI........................................ 71

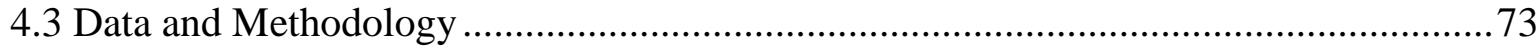

4.3.1 Other control variables........................................................ 75

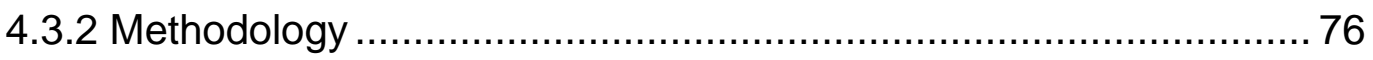

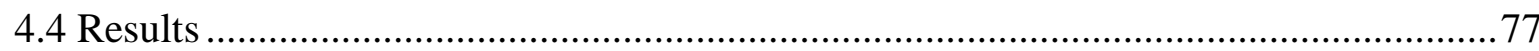

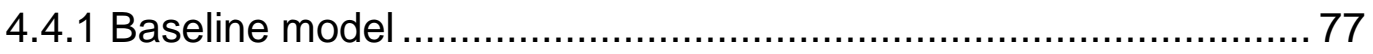

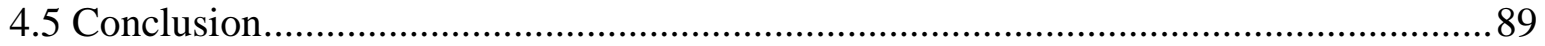

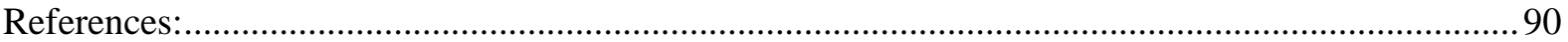




\section{List of Tables}

TABLE 2. 1. TOP 20 RECIPIENTS OF CHINESE OUTBOUND INFRASTRUCTURE PROJECTS FROM 2003 TO 2016...........................15

TABLE 2. 2 SECTORAL DISTRIBUTION OF CHINESE OUTBOUND INFRASTRUCTURE PROJECTS FROM 2003 TO 2016 ........................16

TABLE 2. 3 POISSON PSEUDO-MAXIMUM-LIKELIHOOD (PPML) ESTIMATION. DEPENDENT VARIABLE IS THE TOTAL VOLUME OF

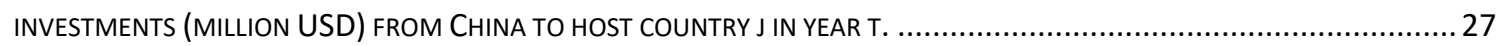

TABLE 2. 4 POISSON PSEUDO-MAXIMUM-LIKELIHOOD (PPML) ESTIMATION. DETERMINANTS OF CHINESE INFRASTRUCTURE OFDI ACCORDING TO INCOME GROUP OF COUNTRIES. DEPENDENT VARIABLE IS THE TOTAL VOLUME OF INVESTMENTS (MILLION USD) FROM CHINA TO HOST COUNTRY I IN YEAR T.

TABLE 2. 5 AdDITIONAL ROBUSTNESS CHECKS. POISSON PSEUDO-MAXIMUM-LIKELIHOOd (PPML) ESTIMATION. DEPENDENT VARIABLE IS THE TOTAL VOLUME OF INVESTMENTS (MILLION USD) FROM CHINA TO HOST COUNTRY J IN YEAR T IN COLUMNS 1 TO 4. IN COLUMN 5, DEPENDENT VARIABLE IS THE NUMBER OF INFRASTRUCTURE PROJECTS FROM CHINA TO HOST COUNTRY J IN YEAR T.

TABLE 2.A. 1 LIST OF COUNTRIES. COUNTRIES THAT RECEIVED INFRASTRUCTURE FDI FROM CHINA FROM 2003 TO 2016 ARE MARKED BY STARS 38

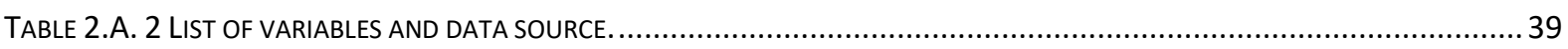

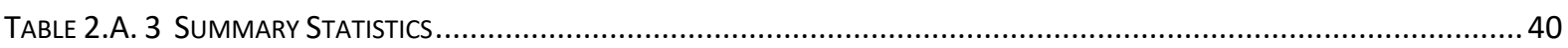

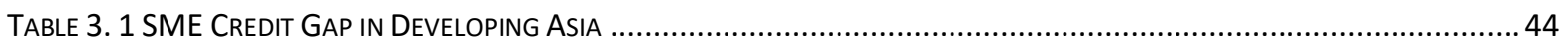

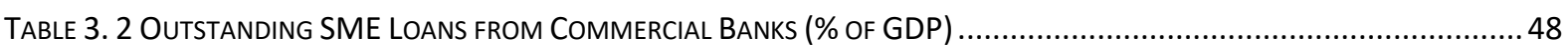

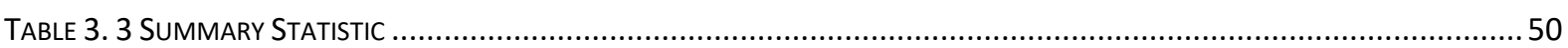

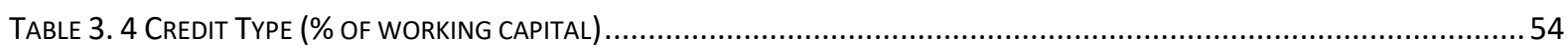

TABLE 3. 5 COUNTRY-SPECIFIC RESULTS. BANK BORROWING (\% WORKING CAPITAL) ......................................................5

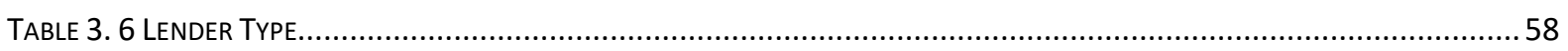

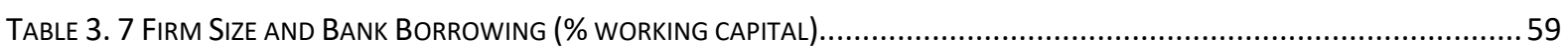

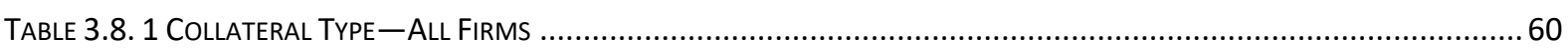

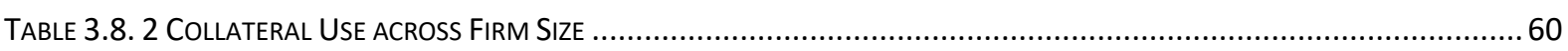

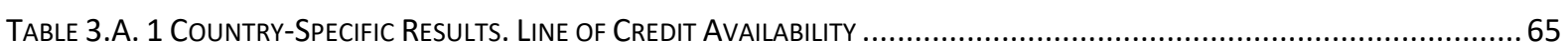

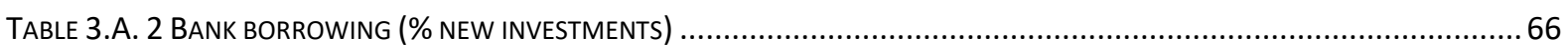

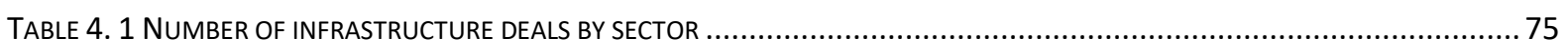

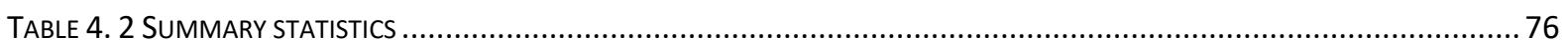

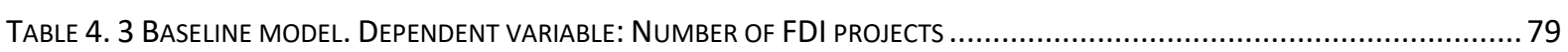

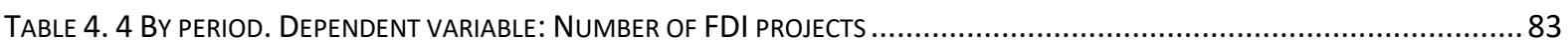

TABLE 4. 5 BY HOST COUNTRY'S DEBT/GDP (QUANTILE BY DEBT/GDP). DEPENDENT VARIABLE: NUMBER OF FDI PROJECTS .........85

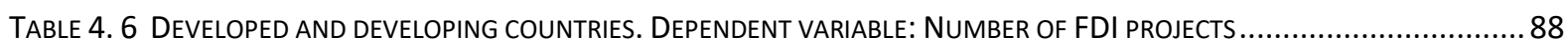




\section{List of Figures}

Figure 2. 1. HeAt MAPS OF China's OUTWARd DiRECT INVESTMENT (ODI) OVER YEARS 2003-2016.

FIGURE 2. 2. THIS FIGURE PROVIDES TRACE PLOTS OF COEFFICIENTS (STANDARDIZED) ON CHINESE INFRASTRUCTURE ODI FIT BY LASSO FOR A CROSS SECTION OF 108 COUNTRIES. THE ESTIMATION USE TEN-FOLD CROSS VALIDATION FOR REGULARIZATION PARAMETERS, USING GEOGRAPHY, INSTITUTIONS, AND MACROECONOMIC CONTROLS.

FIGURE 2. 3. ILLUSTRATES THE HEAT MAP PLOT OF EXPECTED PERCENTAGE CHANGE IN CHINESE ODI ASSOCIATED WITH AN INCREASE IN COUNTRY'S RULE OF LAW INDEX FROM ITS AVERAGE LEVEL TO THE TOP QUINTILE OF THE SAMPLE. 29

FIGURE 2.4 1. EXPECTED PERCENTAGE CHANGE IN CHINA'S ODI FOR A UNIT STANDARD DEVIATION INCREASE IN HOST COUNTRY CHARACTERISTICS: FULL SAMPLE.

FIGURE 2.4 2. EXPECTED PERCENTAGE CHANGE IN CHINA'S ODI FOR A UNIT STANDARD DEVIATION INCREASE IN HOST COUNTRY CHARACTERISTICS: HIGH AND UPPER MIDDLE INCOME GROUP

FIGURE 2.4 3. EXPECTED PERCENTAGE CHANGE IN CHINA'S ODI FOR A UNIT STANDARD DEVIATION INCREASE IN HOST COUNTRY CHARACTERISTICS: LOWER AND LOWER MIDDLE INCOME GROUP

FIGURE 3. 1. SUMMARY STATISTICS. COMPARISON OF MEAN VALUES OF VARIABLES FOR SME AND NON-SME SUB-SAMPLES........51

Figure 3. 2. SOURCES of FINANCE FOR INVESTMENT PROJECTS OF SMES IN DEVELOPING ASIA..........................................55

FIGURE 3.3. 1. ECONOMIC SIGNIFICANCE OF A ONE-STANDARD-DEVIATION INCREASE OF FIRM CHARACTERISTICS ON LINE OF CREDIT

AVAILABILITY (\% PROBABILITY)

FIgURE 3.3. 2 ECONOMIC SIGNIFICANCE OF A ONE-STANDARD-DEVIATION INCREASE OF FIRM CHARACTERISTICS ON PROPORTION OF

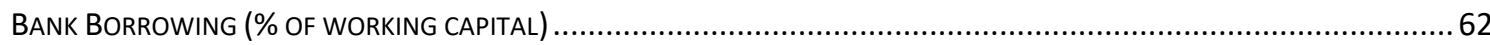

Figure 3.A. 1 ECONOMIC SIGNIFICANCE OF A ONE-STANDARD-DEVIATION INCREASE OF FIRM CHARACTERISTICS ON PROPORTION OF

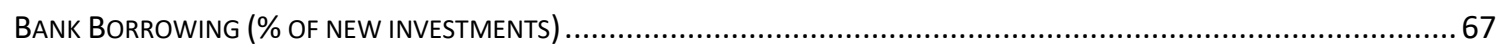

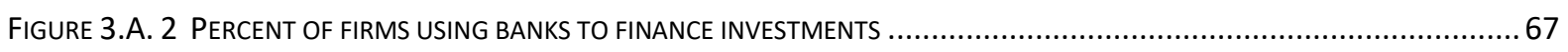

FIGURE 4. 1 NUMBER OF INFRASTRUCTURE PROJECTS OVER YEARS IN DEVELOPING COUNTRIES. 1990-2016 ............................74

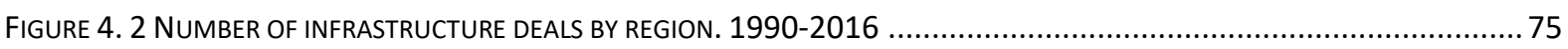


Dedicated to my parents and sisters 


\section{Acknowledgments}

Doing my $\mathrm{PhD}$ has been a long journey, both with its ups and downs and challenges. But, I can confidently say that I enjoyed every bit of it. Not only had it taught me a lot about economics as a science but many other important things that I can't count. For this, I feel fortunate and proud.

I am very grateful to my supervisor Yothin Jinjarak who was always ready for his support and advice through these years. His ideas, reasoning and advice have been crucial and several times they were a turning point on my research outcomes. I learned a lot from him, both academically and as a person. For this, I consider myself lucky to work with and I will always be thankful. I would also like to thank my secondary supervisor Dr. Shutao Chao although I didn't have much chance to work with.

I also wish to express my gratitude to Victoria Business School. Their support and generous scholarship made it possible to start my $\mathrm{PhD}$ here.

Special thanks goes to my friends and relatives back in home for their support as well as to my friends from many other countries I gained through studying and working. Also, many thanks to my PhD colleagues which made my studies enjoyable. They were main source of energy and joy during my stay here.

And most importantly, I am very grateful to my parents and sisters for their continuous support and motivation. Without them it would be very difficult to imagine where I am today. Words cannot express how I am grateful to them. 


\begin{abstract}
This thesis consists of three empirical essays on Foreign Direct Investment (FDI) and Small Medium Enterprise (SME) access to finance. The first essay examines determinants of Chinese Outward Direct Investment (ODI) in infrastructure sectors. This study focuses on the role of host country institutions, macroeconomic stability and geography on attracting Chinese ODI. Utilizing micro-level project data over the years 2005 to 2016, results show that Chinese infrastructure investments are attracted to countries with a limited fiscal space but strong institutions. We also find that geographic distance, cultural proximity, Free Trade Agreement with China, country size are important factors in attracting Chinese investments. The second essay studies SME access to finance in Asia. We investigate the relative importance of external finance vis-à-vis internal finance for SME and larger firms and examine how SME characteristics associated with the extent of their bank borrowing. Results indicate that bank borrowing and line of credit availability are positively associated with financial audit, managerial experience, export participation, and ISO certificate, while it is negatively associated with foreign ownership and SME status. Our research suggests that access to finance is an important concern in Asia and government intervention targeting improvement in credit guarantee systems, monitoring and credit scoring can help easing the constraints for SME access to external finance. Finally, the third essay examines the role of infrastructure investment deals as a signaling on attracting FDI. Intriguingly, we find that infrastructure deals produce a negative signal to MNEs' decision making for developing countries. We look for several channels in which the negative signaling effect can pass through. Findings suggest that increase in global risk aversion stemming from global financial crisis and country specific risk level are the main factors behind the negative signalling effect.
\end{abstract}




\section{Chapter 1}

\subsection{Introduction}

Foreign Direct Investment (FDI) continues to be of the main drivers of economic growth in developing countries. As an important source of external finance, FDI brings new investments, create new jobs, transfer knowledge and technology to developing counties. For this reason, attracting foreign investors have been central focus to economic development for policy makers over the last decades. This in turn, have led to rapid increase in FDI flows to developing countries. According to UNCTAD (2015), over last 30 years FDI inflows in developing countries have increased sharply from $\$ 7.4$ billion USD in 1980 to more than $\$ 680$ billion USD in 2014. Parallel to this, there have been growing body of scholars examining the main drivers of these flows as well as their contribution to host country economies. While these studies have made significant contribution to FDI literature, there still remains new room for more analysis. Thus, two chapters (the second and fourth chapter) of this thesis address some of these issues.

The second chapter of thesis looks at a particular type of FDI, FDI in infrastructure, which has been largely ignored in literature despite it being one of the most conducive and productive type of FDI flows. More precisely, we look at what are the key factors driving these flows from China, one of the main global suppliers of infrastructure projects. As a rising power and being one of the world's biggest investors, China has been playing a key role in provision of overseas infrastructure projects. Despite the remarkable expansion of Chinese Multinational Enterprises (MNEs) with large scale overseas infrastructure projects, none of the previous studies have examined the key factors attracting these investments. Thus, in second chapter of this thesis we investigate the key determinants of Chinese overseas infrastructure projects with a particular focus on the role of host country institutions and fiscal space. Using micro-level project data over the years 2005 to 2016, and employing Least Absolute Shrinkage and Selection Operator (LASSO) and Poisson Pseudo Maximum Likelihood (PPML), the estimation results show that host countries (145) with a limited fiscal space but strong institutions are among the strongest determinants for Chinese outward direct investment (ODI) in infrastructure. Moreover, we also find that larger market size, cultural and geographical proximity, free trade agreement with a host country are strong influential factors for Chinese outbound infrastructure projects. 
The next chapter aims to understand the Small Medium Enterprise (SME) financing and study how firm characteristics are related to access to finance in South Asia. SMEs have important contribution to economic development in Asia accounting more than $60 \%$ of employment in many parts of the region. However, due to their small size, lack of collateral they face challenges in borrowing from banks and other financial institutions. According International Finance Cooperation (IFC) $70 \%$ of SMEs struggle to access finance in Asia where the total financial gap is approximately $\$ 100$ billion, an average of $\$ 400,000$ per SME (Stein et al. 2013). In the background of these broad range of issues, we aim to address what are the main barriers to SME access to finance and how other firm characteristics are related to the extent of their bank borrowing. Using World Bank Enterprise Survey, a cross-country firm-level data we also examine other several aspects of SME finance, including line of credit availability, type of collateral used, and type of credit and lenders (i.e., commercial, state owned banks and other lenders). Our main findings suggest that SME status is negatively associated with bank borrowing and line of credit availability. Furthermore, findings show that export participation, ISO certification and financial audit have positive and statistically significant effect on SME external financing. Our results confirm that SMEs remain dependent on internal finance and their access to external financing is an important concern in Asia. In the background of our findings, we suggest that implementation of government policies regarding collaterals and credit guarantees in the interim are highly helpful to SME financing along with improving the financial and legal institutions as a part of long term policy.

Finally, the fourth chapter of this thesis looks at the role of infrastructure investment deals on attracting FDI. Infrastructures are very particular type of investments with high potential on improving economic activity by boosting productivity and employment in host country. In addition, they contain valuable source of information for foreign investors as they involve large scale capital, facing high regulatory, economic and political risk. Therefore, we argue that announcement of an infrastructure deal should transmit a positive signal to multinational firms as they contain critical information regarding the country fundamentals incorporated within the deal. However, on the other side, there is also greater risk involved with the project itself. More specifically, large scale infrastructure projects may introduce new debt vulnerabilities to countries with limited resources and higher debt burden creating challenges for sovereign debt sustainability (Hurley et. al., 2018). This in turn may compromise the credit stability of host country economy causing loss of trust in FDI firms. Considering all the facts noted above, we test for several channels in which negative or positive signalling can pass through. Our findings 
indicate that during the stable period, foreign investors see less risk embedded in infrastructure projects, and thus the signalling is positive. However, the signalling is negative during the crisis period as foreign investors see larger amount of risk to the host country embedded in infrastructure deals. Further analysis shows that this negative channel stems from distressed situations that emerges from host country's specific risk level. Particularly in heavily indebted countries, the abundance of recent infrastructure projects may escalate the risk of debt distress, increasing the probability of government default and economic instability in the near future and thus discourage foreign investment. 


\title{
Chapter 2
}

\section{Globalizing Chinese Infrastructure Investment: The Role of Host- Country Geography, Institutions, and Macroeconomic Stability}

\begin{abstract}
Motivated by the rapid globalization of Chinese infrastructure outward direct investment (ODI), we examine micro-level project data over the years 2005 to 2016 to analyse its driving factors. Using Least Absolute Shrinkage and Selection Operator (LASSO) and Poisson Pseudo Maximum Likelihood (PPML), the estimation results show that host countries (145) with a limited fiscal space but strong institutions have been attractive to Chinese infrastructure investments. In addition, we also find that geographic distance, cultural proximity, Free Trade Agreement with China, country size are among the determinants for Chinese ODI in infrastructure. Moreover, conditioning on geographic, macroeconomic controls, and fiscal constraints, we find that the improvement in institutional quality potentially have the largest economic significance on Chinese infrastructure ODI in Africa, Latin America, Eastern Europe, and South Asia.
\end{abstract}




\subsection{Introduction}

Over the last decade the outward foreign direct investment from emerging markets and especially from China have been the subject of debate. Having been one of the major destinations for FDI itself, China now is globalizing its outbound investment, currently being ranked as the world's third largest outbound investor (OECD, 2014). According to the Ministry of Commerce of the People's Republic of China (MOFCOM, 2014), total annual outbound FDI reached US\$ 119.6 billion in 2014, becoming a net creditor of FDI for the first time. The reason is clear. China needs to find more effective ways of using its nearly US\$4tn of accumulated foreign reserves, by switching from its low yielding portfolio investment that mainly goes into US treasuries towards higher-yielding direct investment. As the Chinese economy rebalances and the services sector gains more importance, foreign investments is increasingly aimed to satisfy the search for long-term yields and for its businesses to move up the value chain. One overseas sector that constitutes significant portion of Chinese attention is infrastructure where China is utilizing its significant global construction and engineering capability and at the same time generating demand for its exports.

This flow of capital is attractive to host countries especially at the time when global economy suffers from large underinvestment in infrastructure. According to the World Economic Forum's Positive Infrastructure Report the world faces a global infrastructure deficit of \$2 trillion per year over the next 20 years (World Economic Forum, 2010). Increasing urbanization combined with strained public finances and pressured household incomes resulted in poor infrastructure spending in many parts of the world. To meet this demand in the face of restricted financial resources, governments is in strong search of alternative ways to finance their infrastructure deficit. As a result, the rapid expansion of Chinese Multinational Enterprises (MNEs) with large scale overseas infrastructure projects as well as recent China led initiatives, e.g. One Belt, One Road and the Asian Infrastructure Investment Bank have generated strong worldwide interest. This may be good news for China and the rest of the world. From one side China is trying to make better returns on its accumulated foreign reserves by investing on long term assets, while host countries need fast growing source of funding at the current time of low economic growth and strained budget constraints. On the other side, strong concerns have been raised particularly noting that investments flow more to economically riskier and poorly governed countries, exploit their natural resources, political objectives are favored to economic ones, etc. 
However, despite these controversial debates and rapid expansion of Chinese overseas infrastructure projects through FDI, surprisingly no empirical study still exists to test the motives behind Chinese OFDI in this specific sector. Few studies satisfy only with descriptive statistics or country specific case studies perhaps due to the scarcity of sufficiently disaggregated or incomplete data to allow formal analysis of Chinese OFDI in this context. To our knowledge, this is the first attempt to empirically study determinants of Chinese outbound infrastructure projects through FDI. Using the fDi markets database over the years 2005 to 2013, we analyse what are the main factors that that attract these greenfield investments from one of the world's largest investors. Why are some countries able to attract more infrastructure investments in the form of FDI than others? By defining infrastructure projects from industry level disaggregated FDI database, this paper aims to provide answers to these questions.

Several hypotheses have been developed in this study in order to test motives behind Chinese MNEs. Particularly, gravity motives, trade links with China, host government financial constraints, the level of infrastructure and quality of institutions in host countries, endowment of natural resources and macroeconomic stability channels have been used to identify main motivations behind China's expanding overseas investments. Employing Poisson Pseudo Maximum Likelihood (PPML) estimation method the results show that governments with a combination of higher fiscal deficit and strong institutions, countries with larger market size have strong effect on attracting Chinese infrastructure investments. We also find that the national agglomeration effect and Free Trade Agreements are important determinants whereas physical distance and host country macroeconomic stability do not matter for Chinese ODI in infrastructure. $^{1}$

The rest of the paper is structured as follows: Section 2.2 reviews empirical literature on the Chinese OFDI and the determinants of foreign investment on infrastructure projects. Section 2.3 introduces hypothesis development. Section 2.4 provides descriptive overview of Chinese OFDI and the sources of databases used in this study. Section 2.5 presents the empirical model and estimation method. Section 2.6 describes the results obtained and Section 2.7 concludes.

\footnotetext{
${ }^{1}$ By noting the national agglomeration effect, we mean number Chinese FDI projects outside of infrastructure sector in host country.
} 


\subsection{Related Studies}

Subject to data availability, there have been very few studies on the sector specific determinants of FDI, particularly the infrastructure sector given its special nature. However, there are considerable amount of empirical and theoretical studies on the locational determinants of FDI which are mostly concentrated on Dunning's internationalization theory (Dunning J., 1977). The theory suggests that there are four main motivations behind FDI: market seeking; efficiency seeking; resource seeking and strategic asset seeking. Market seeking FDI aims to protect existing markets or to gain access to new foreign markets. Efficiency seeking FDI can be understood as a cost reduction strategy when MNEs move production to counties where inputs are comparatively cheaper. Recourse seeking FDI occurs when firms wish to acquire resources at a lower cost than their home country. Strategic asset seeking FDI is aimed at acquiring assets to strengthen their global competitiveness (Dunning J. , 1977).

However, given the particular nature of MNEs from emerging markets, especially from China, the motives behind the determinants of FDI can be quite different from those traditional theories of FDI (Buckley, et al., 2009). Unique features of Chinese MNEs can be briefly described as follows: (1) State owned enterprises constitute significant amount of outward FDI, where the government plays an influential role in directing these investments (Buckley, et al., 2009; Morck, Yeung, \& Zhao, 2008); (2) Chinese MNEs possess comparative advantages in terms of easy access to capital below market rates and have experience of operating in a place with similar institutions and government control (Buckley, et al., 2009; Quer, Claver, \& Rienda, 2012). In fact, Quer et al. (2012) argue that particularity of China's institutional environment provide these investors a firm specific advantages that are better at handling risks associated with operating in countries characterized by weak governance, political and economic uncertainty; (3) Neighbor countries with ethnic and cultural close ties are among preferable destinations (Lecraw, 1993); (4) FDI from Chinese MNEs have mostly been determined by "pull" factors such as acquiring resources in order to satisfy their growing demand and short supply in their domestic markets rather than "push" factors (e.g. home market limitations, labor shortage) that are more usual for MNEs from developed countries (Deng, 2004).

So far, empirical studies on the determinants of Chinese OFDI find both conventional and contradictory results to the general theory of multinational firms. Particularly, several empirical studies find a strong support for market seeking motivation of Chinese MNEs which are in line 
with the existing theories (Buckley, et al., 2009; Amighini, Rabellotti, \& Sanfilippo, 2013; Cheng \& Ma, 2010; Kolstad \& Wiig, 2012). Buckley et al. (2009), one of the earlier authors to study determinants of Chinese outward FDI, find that although Chinese OFDI is associated with host market size, geographical and cultural proximity, they are also attracted to politically risky and natural resource abundant countries. This is explained by the fact that these investments are dominated by state-owned companies which give them firm specific advantages to access for low cost of capital and ability to operate in a highly regulated and risky environments. Similar results are further supported by later studies. Ramasamy et al. (2012) find that determinants of Chinese OFDI differ based on ownership. Their findings suggest that mostly state owned enterprises are attracted to counties with politically risky environments and large source of natural resources whereas private enterprises are more market seekers. Kolstad \& Wig (2012) show that institutions and natural resources have an interactive effect, clarifying that the worse the institutional quality of a host country, the more is Chinese outward FDI attracted by the country's natural resources. Furthermore, Amighini et al. (2013) study determinants of Chinese OFDI distinguishing by both industry and income level of host countries. According to their findings, Chinese enterprises are invariably attracted by marketseeking motivations, whereas attraction to natural resources are relevant for manufacturing and resource intensive sectors. Furthermore, they find evidence that outward FDI are positively associated with Chinese bilateral trade flows particularly in services sector to support their export activities. Similar results are found by Aizenman, Jinjarak \& Zheng (2018) in relation to Chinese bilateral trade flows and OFDI. They find evidence that the association of Chinese OFDI and trade are flows are further intensified with the provision of swap lines to China's trading partners.

So far very few empirical studies (Amighini et al., 2013; Aizenman et al., 2018) concentrate on sector specific determinants of Chinese FDI possibly due to the lack of sufficiently disaggregated data. This paper adds to the literature by studding the determinants of Chinese OFDI in infrastructure sector. Estimation in this study cover wide range of countries and is more up to date. 


\subsection{Hypothesis Development}

The following hypotheses are derived from empirical literature on determinants of Chinese Outward FDI. Also, several studies on the locational determinants of infrastructure specific FDI are considered to analyze their influence on Chinese ODI in this sector.

\section{Endowment of natural resources; "Resource for infrastructure swap"}

Empirical literature finds mixed results on resource seeking motives of Chinese OFDI. While some have shown (Buckley, et al., 2009; Sanfilippo, 2010; Aizenman, Jinjarak, \& Zheng, 2018) a positive relationship between Chinese OFDI and host country endowment of natural resources, others find that this effect is either very small or is particular for specific regions (Bhaumik \& Co, 2011; Cheung \& Qian, 2009). The association of Chinese OFDI with access to natural resources is not surprising, since China seriously lacks natural resources to support its remarkable growth. This is particularly more common in resource-rich developing countries, where Chinese MNEs offer to build infrastructure projects like hydropower stations, dams and roads in return for affordable and continuous supply of natural resources. This is a so called "resource for infrastructure swaps" which future revenues from resource exports are used as collateral for infrastructure development (Konijn, 2014). This mode of entry is used by Chinese state -owned MNEs mainly in countries with weak institutions and low credit ratings to lower financial risks in regions such as Africa and Latin America. These type of contracts were usual in countries such as Angola, DR Congo when they had limited access to external finance and strained relations with international financial institutions (Konijn, 2014). Besides, given the political importance of oil, controlling energy resources may also be of strategic importance to China.

Therefore, in order to test the relevance of resource seeking motive, the following hypothesis is suggested:

\section{H1. China's OFDI in infrastructure is attracted to countries with large natural resources}

\section{Institutional factors}

The established literature on FDI suggests that countries with higher institutional quality and better legal protection records are associated with higher levels of attractiveness for FDI. But surprisingly, several studies have shown that Chinese OFDI are linked with higher political uncertainty and weak institutional environments (Buckley, et al., 2009; Kolstad \& Wiig, 2012; 
Ramasamy, Yeung, \& Laforet, 2012). These facts are usually explained by reasoning that Chinese OFDI is promoted by political connections between China and other developing host countries, and therefore they tend to be less risk averse. However, since the main objective of this paper is to study the determinants of infrastructure projects from China, not gross Chinese OFDI, the previous findings on institutional factors may not hold true for this specific sector. In fact, infrastructures are very complex projects and sustainability of these projects depends very critically on the regulatory environment. Risks involve not only the foreign investors, but also regulatory setting of every country, especially if public sector is highly involved in the project. Additionally, infrastructures are long-term projects and this nature makes them difficult to complete in many places of the world. The longer time it takes to complete a project because of an inefficient government decision making process, the higher the costs will be for the investors in terms of human and financial resources (Sader, 1999). Therefore, investors look at these fundamental conditions when deciding in which country they invest in. Effective and efficient governance increases investor confidence and sustains market incentives. As a result, we propose the following hypothesis:

H2. Outbound infrastructure investments from China are attracted to countries with strong institutional quality and effective governance.

\section{Fiscal constraints}

Usually, strong fiscal position is considered as another indicator of economic stability and high levels of fiscal deficit may increase perceived country risk. Higher fiscal imbalance may limit the ability of the government to carry out stabilizing policies and is an important factor of country risk rating. Several studies have found that country's fiscal position is an important determinant of FDI flows. Amaya and Rowland (2004) find that investors prefer countries with sound fiscal policies and strong fiscal balance fosters FDI flows. Their results suggest that FDI flows seem to be directed to countries that have prudent fiscal policies, as countries suffering from higher fiscal imbalance are prone to increase tax rates and therefore negatively impact FDI. Likewise, Holland and Pain (1998) find that the measures of external stability such us debt/GDP ratio have a significant impact on FDI flows.

However, in the context of this study the effect of a government's fiscal position can be quite ambiguous. Generally, infrastructure projects have been financed with public funds. However, public deficits, reduced government revenues and fiscal pressures have led to strong reduction of government commitments to such investments (OECD, 2015). These policies, combined 
with increasing urbanization and demographic pressures, led to discrepancy between limited supply and increasing demand for infrastructure in many places of the world. Therefore, at the period of scarce financial resources, governments are in growing need to find alternative ways to fill their infrastructure gap. As a result of increasing public capital shortage, governments tend to be more open to private/foreign investors to finance this gap (Etienne, Hammami, \& Ruhashyankiko, 2006). Thus, countries with large deficits and higher debt burden are expected to attract more foreign direct investment as a result of their financial constraints. Therefore, bearing in mind all these arguments, the effect of government/fiscal constraints can either be negative or positive and the prediction on this variable is left open.

Apart from the direct effects of institutions and fiscal constraints, it is also reasonable to believe that the effect of these two on Chinese OFDI are linked. In other words, it is possible that the effect of government constraints/fiscal burden on FDI depends on the level of institutional quality in the host country. Better institutional quality and legal protection may outweigh the risks associated with the fiscal position of the country.

Thus, higher fiscal burden combined with a predictable policy environment that ensures the rule of law and the enforcement of contracts is expected to stimulate foreign direct investment.

H3. Higher fiscal burden combined with a strong institutional quality are expected to have a positive effect on Chinese OFDI in infrastructure.

\section{Trade links with China}

Number of studies have found that Chinese MNEs are inclined towards investing in countries that are already a significant market for Chinese goods (Amighini, Rabellotti, \& Sanfilippo, 2013; Aizenman, Jinjarak, \& Zheng, 2018; Buckley, et al., 2009). This complementary relationship between FDI and bilateral trade was especially important during the early phase of Chinese OFDI when these investments took place mostly to provide a local support for domestic Chinese exporters ( $\mathrm{Wu} \& \mathrm{Sia}, 2002)$. These links particularly could be more important in our context since trade intensity with the host country could imply higher necessity for establishment of transportation, logistics and other infrastructure services to support Chinese exports and imports in these countries. Additionally, higher trade intensity with its partner may indicate better knowledge of the host market and its demand expectations and thereby, reduce transaction costs of investing. Bearing in mind all these facts, a positive association between Chinese OFDI and volume of bilateral trade is expected. 
H4. The higher the volume of bilateral trade between China and a host country the more Chinese infrastructure investments are attracted to these countries.

Apart from the importance of bilateral trade on FDI flows, empirical studies have also found strong support for the positive effect of regional or bilateral Free Trade Agreements (FTA) on FDI (Neumayer \& Spess, 2005; Aizenman, Jinjarak, \& Zheng, 2018). As Free Trade Agreements are usually aimed to reduce risks and uncertainties on overseas investments, foreign investors feel more confident while expanding abroad. Between 2003 and 2012 China has established 10 FTAs with its 20 trading partners since its accession to World Trade Organization (WTO). A detailed analysis of our sample suggests that Chinese investors indeed are more frequently engaged in FDI activities with these countries. It is therefore reasonable to believe Chinese OFDI to increase with the establishment of bilateral free trade agreements with host countries.

H5. Free Trade Agreement (FTA) with a host country is likely to attract more infrastructure investments from Chinese MNEs.

The subsequent hypothesis relates to the national agglomeration effect of FDI. National agglomeration effect may occur when Chinese firms prefer to locate in places where cluster of other Chinese investors exist. Although previous findings are ambiguous on the effect of agglomeration, we expect a positive association between Chinese outbound infrastructure investment and clusters of other Chinese firms. This could be explained by the fact that there will be a greater demand and necessity by other Chinese firms for improved infrastructure facilities. For instance, availability of other Chinese automobile makers or semiconductor electric manufacturers may require better transportation and high quality warehousing logistics infrastructure. Furthermore, the existence of these firms in host country may help new investors reduce uncertainties about the local markets, provide them with further insights in gauging additional market potential or economic risks in this countries, assist them with foreign laws and regulations and legal culture.

H6. Infrastructure investors from Chinese MNEs tend to be attracted to host countries where other Chinese FDI are concentrated. 


\subsection{Data}

Data on dependent variable, i.e. annual flow of Chinese Outward FDI in infrastructure is derived from fDi Markets database provided by Financial Times Ltd. This database tracks cross border greenfield investments across all sectors and countries worldwide, provides a detailed information on each FDI project categorized by industry sector, sub-sectors, business activities and industry clusters. This decomposition of each industry sector allows us to define and to extract information on Chinese outward infrastructure projects over the study period. ${ }^{2}$ It further contains information on investing and parent company name, the amount of capital investment (USD millions) and jobs created in destination cities.

\subsubsection{Descriptive overview of Chinese outward infrastructure FDI}

fDi Markets database records total number of 4,395 overseas greenfield investment projects by Chinese firms for the period of 2003-2016 in 145 host countries (Appendix Table 2.A1). A brief outlook in the data reveals that over these years 99 host countries received infrastructure investments from China. These infrastructure projects can be classified into 4 groups: Construction, Electricity, ICT/internet infrastructure, Transportation and other infrastructure related public services, e.g. water transportation and water sewage systems, warehousing \& storage. Total value of these projects exceed 204 billion US dollars, out of which significant amount have been directed to emerging and developing countries. Figure 2.1 illustrates a heat map of China's aggregate and infrastructure ODI over years from 2003 to 2016, respectively. Table 2.1 shows distribution of Chinese overseas infrastructure investments by country. A closer at the table look at the reveals that USA, UK, Australia and South Korea are the top receivers among developed countries. Emerging countries such as Egypt, India, Malaysia and Pakistan host more than $34 \%$ of total investments.

\footnotetext{
${ }^{2}$ Although there is no unique definition for infrastructure, we include the following services when using the infrastructure term: electricity generation and distribution, telecommunications, transportation, water and waste treatment, construction of education, health and other public related services, roads, airports, ports, railways, public transport. See Sader.F (2000).
} 
Figure 2. 1 Heat maps of China's Outward Direct Investment (ODI) over years 2003-2016.

Heat map plot of China's aggregate ODI
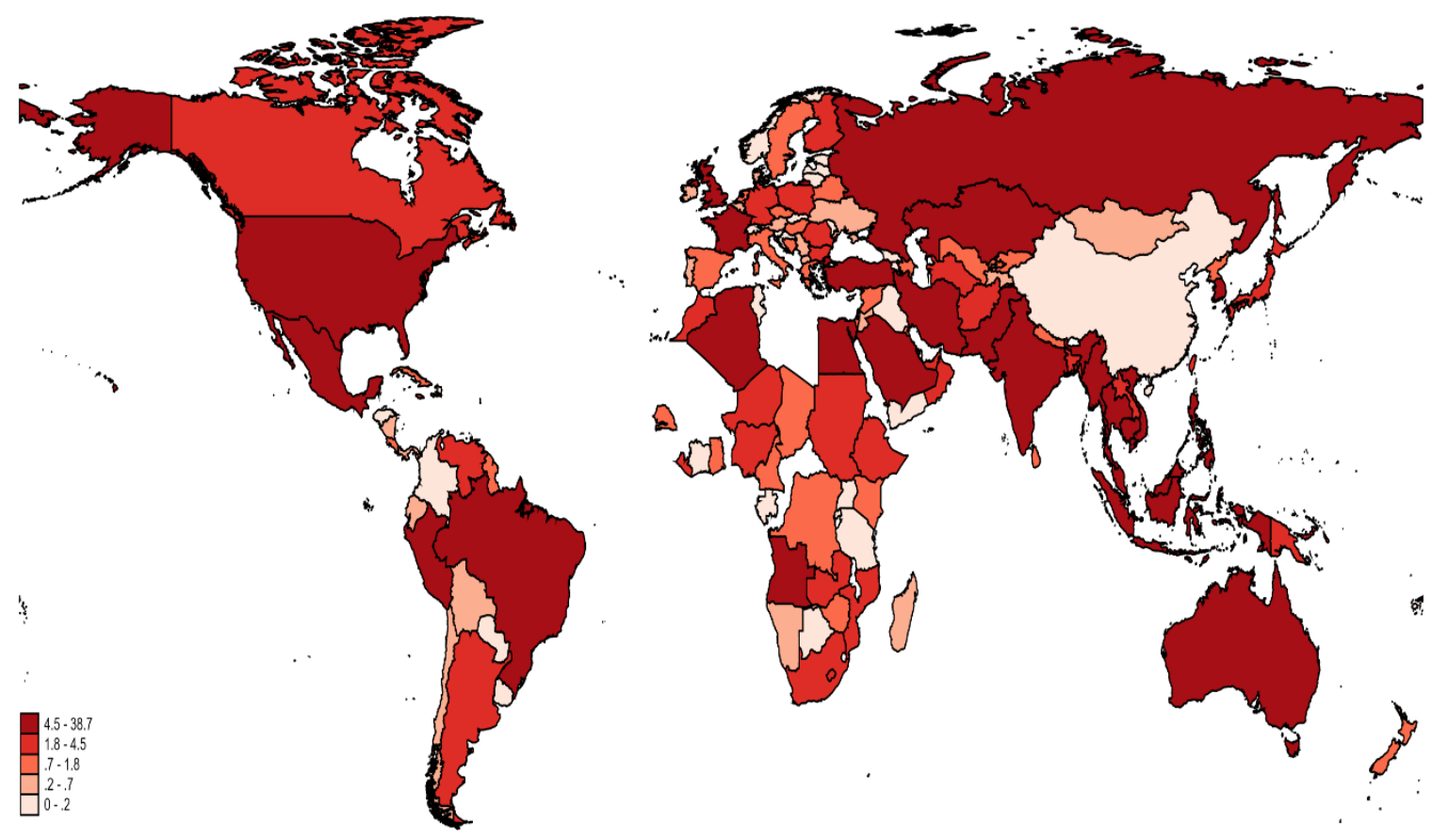

Heat map plot of China's ODI in infrastructure
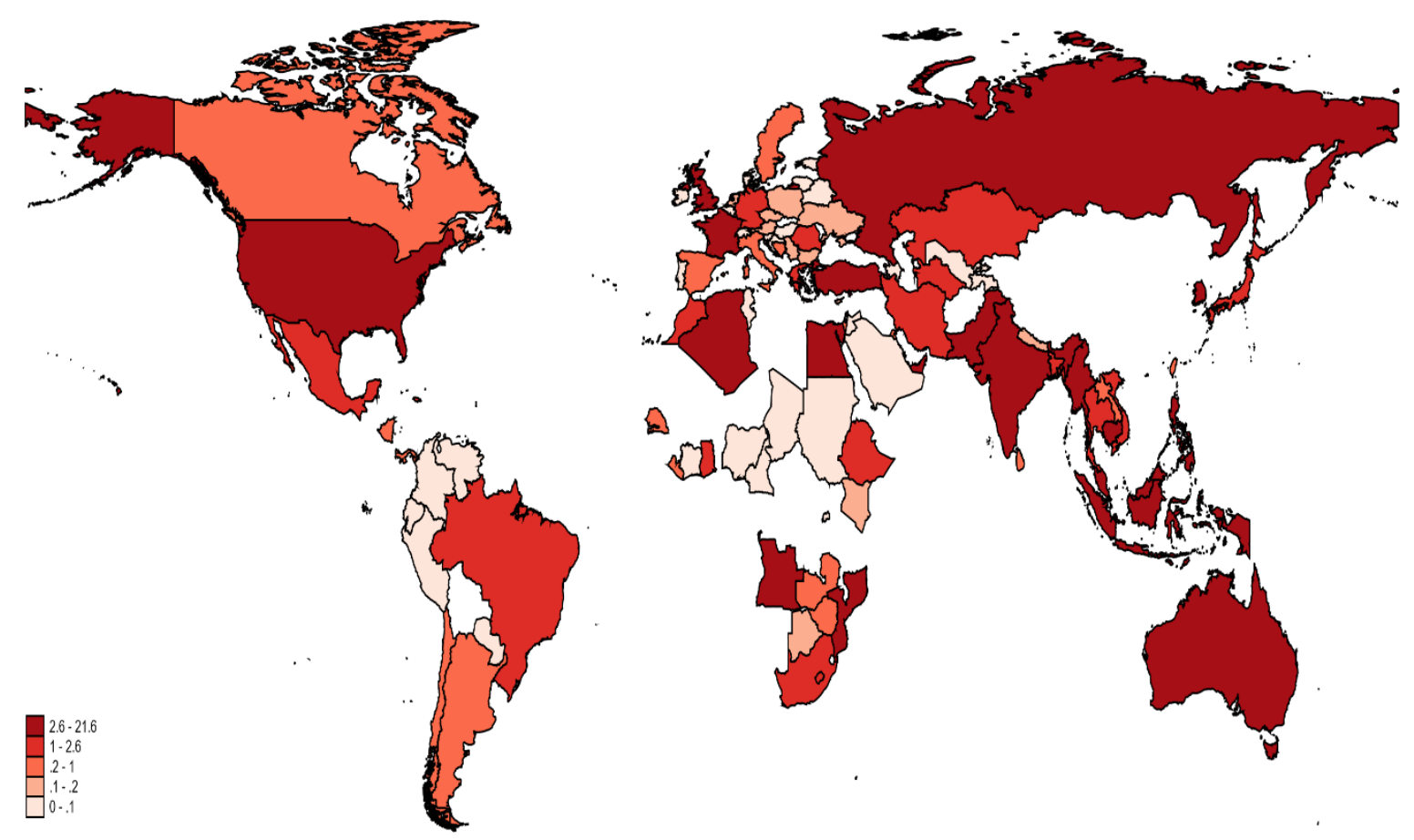
Table 2. 1. Top 20 recipients of Chinese outbound infrastructure projects from 2003 to 2016

\begin{tabular}{lccc}
\hline Top 20 Recipients & Capital Investment (Million USD) & Percentage of Total & Cumulative \\
\hline Egypt & 21566.3 & 10.6 & 10.6 \\
India & 18358.5 & 9.0 & 19.6 \\
Malaysia & 16862.9 & 8.3 & 27.9 \\
United States & 16046.1 & 7.9 & 35.7 \\
Pakistan & 12446.3 & 6.1 & 41.8 \\
Indonesia & 10242.6 & 5.0 & 46.8 \\
UK & 9739.6 & 4.8 & 51.6 \\
Australia & 5412.2 & 2.7 & 54.3 \\
Russia & 4527.5 & 2.2 & 56.5 \\
Korea & 4430.9 & 2.2 & 58.7 \\
Turkey & 4194.5 & 2.1 & 60.7 \\
Philippines & 4157.0 & 2.0 & 62.7 \\
Mozambique & 4000.0 & 2.0 & 64.7 \\
Angola & 3835.0 & 1.9 & 66.6 \\
France & 3693.3 & 1.8 & 68.4 \\
Myanmar & 3601.4 & 1.8 & 70.2 \\
Algeria & 3300.0 & 1.6 & 71.8 \\
Cambodia & 2999.3 & 1.5 & 73.2 \\
UAE & 2801.5 & 1.4 & 74.6 \\
Hong Kong & 2618.5 & 1.3 & 75.9 \\
\hline Total top 20 & & & -1.9 \\
Total All Countries & 204080.614 & 100 & -1 \\
\hline Source: Author & & & \\
\hline
\end{tabular}

Source: Author's calculation from FDIMarkets.com

Table 2.2 shows that most of infrastructure investments have been allocated to construction activities $(45.5 \%)$ followed by electricity (34.6\%), transportation (9.9\%) and ICT and internet infrastructure (5.2\%) sectors. While $48 \%$ of these investments have been directed only to high income countries, around $28 \%$ of total Chinese ODI in infrastructure have been received by lower and lower middle income countries. 
Table 2. 2 Sectoral Distribution of Chinese outbound infrastructure projects from 2003 to 2016

\begin{tabular}{lccc}
\hline Sectors & $\begin{array}{c}\text { Capital Investment } \\
\text { (Million USD) }\end{array}$ & Number of Projects & \% of Total Capital Investments \\
\hline Construction & 92907.7 & 118 & 45.5 \\
Electricity & 70655.7 & 136 & 34.6 \\
Transportation & 2030.9 & 39 & 9.9 \\
ICT \& Internet infrastructure & 10515.8 & 68 & 5.2 \\
Others & 9695.6 & 271 & 4.8 \\
Total & 204080.6 & 632 & 100.0 \\
& & & 48.5 \\
High Income & 57727.7 & 333 & 23.2 \\
Upper Middle Income & 47355.3 & 158 & 28.3 \\
Lower \& Lower Middle & 98997.7 & 141 & \\
Income & & & 2 \\
\hline
\end{tabular}

Source: Author's calculation from FDIMarkets.com

\subsubsection{Variables description:}

A large set of explanatory variables have been considered in literature as the main determinants of Outward Foreign Direct Investment. However, not all of them can be generalised for a particular country, especially for emerging countries like China. Several variables that are largely used in previous studies were insignificant to explain main motivations of Chinese MNE's in this study. In fact, variables such as host country GDP per capita, GDP growth rate, exchange rates, and openness of the economy (measured by exports + imports/GDP), corporate tax rates were not statistically significant and therefore were not included in the main specification. Hence, this section describes only the main explanatory variables that are used to test each hypothesis developed in section 2.3.

\section{Variables used to test each hypothesis:}

To test our first hypothesis $(H 1)$, we include total natural resource rents (natResc), expressed in a percentage of host country GDP. As a robustness check, we also use a different proxy for resource endowments (Resourc/export) measured as a share of fuels, ores and metals in host countries' total merchandise exports. Controlling for these variables are particularly relevant in our case since infrastructure investments in some resource-rich developing countries are paid by long term supply of commodities, such as oil and gas (Aizenman, Jinjarak, \& Zheng, 2018). Both variables are derived from World Development Indicators. 
Another set of variables has been considered to test the next hypothesis $(H 2)$ are institutional variables. Previous findings on FDI have shown that weak institutions discourage FDI. In our case it is particularly important, since infrastructure projects in general are long term investments and require strong government involvement. Therefore, poor legal protection and weak regulatory environment make these projects difficult to implement, increase the risk of expropriation or result in the failure of projects. Foreign investors investing in long term projects are usually more risk averse to uncertainty and countries with weak regulatory institutions are likely to receive low level of foreign and private investment. Therefore, in order to take into account the role of institutions we include the following variables to measure the regulatory environment in the host countries. Rule of law index (rulelaw) is utilized as a main variable to measure the legal environment and the effect of host country institutions on the flow of infrastructure investments from China. Additionally, to check for importance of other similar measures and for robustness purposes, we control for additional institutional indices. Particularly, government effectiveness index (goveff), control of corruption (corrupt) and voice and accountability (voice) variables are considered as alternative measures of host country institutions. ${ }^{3}$ All these indices are measured as the percentile rank ranging from 0 (lowest rank) to 100 (highest rank) and are collected from World Governance Indicators.

As already discussed in section 2.3, governments with higher fiscal constraints find limited financial resources to allocate in their infrastructure services (Etienne, Hammami, \& Ruhashyankiko, 2006). Thus, governments with excess fiscal burden and restricted budgets are presumed to rely more on private and foreign investors to fill their infrastructure gap. This reasoning combined with better host country institutional environment are therefore expected to attract more provision of Chinese infrastructure services (H3). This hypothesis can be tested by including an interaction effect between host country institutions and fiscal constraints. Several variables have been considered in this study to capture fiscal constraints such as:

\footnotetext{
${ }^{3}$ Rule of law index captures the quality of contract enforcement, courts, property rights, police and the likelihood of crime and violence. Government effectiveness index measures perceptions of the quality of public services, quality of policy formulation and implementation and the credibility of the government's commitment to these policies. Voice and accountability reflects perceptions of the extent to which a country's citizens are able to participate in selecting their government, as well as freedom of expression, freedom of association, and a free media. Control of corruption captures perceptions of the extent to which public power is exercised for private gain, including both petty and grand forms of corruption, as well as "capture" of the state by elites and private interests.
} 
general government balance (\% of GDP); total debt to export ratio; general government deficit (\% GDP) and public debt (gross government debt as \% of GDP). However, due to highly missing values in total debt to export ratio and general government balance variables we excluded them from estimation. Hence, the final sample considers only general government deficit (govDef), and public debt (pubdebt) and their interaction with institutional variables to evaluate this channel. ${ }^{4}$ Additionally, gross disposable income (gross national savings as $\%$ of GDP) is included in all regressions to test whether countries with less national savings have an impact on attracting more foreign investment. The size of national savings has important implications for an economy since it provides additional source of funds available for domestic investment. The data on these variables is collected from IMF's World Economic Outlook and Historical Public Debt Database.

As also noted before, host country trade intensity with China may also be an influential factor in decision making process of Chinese MNEs when investing abroad (H4). Hence, taking into account the importance of trade links as literature suggests, China's bilateral trade (BiTrade) variable is included to test this hypothesis. Bilateral trade is measured as a sum of China's exports and imports with a host country in a given year divided by its total trade. These bilateral trade volumes are expressed in million US dollars and are drawn from China Statistical Yearbook, National Bureau of Statistics of China.

As further additional variables that may explain trade and economic links with host countries we consider Free Trade agreement (FTA) with a host country (H5). FTA is a dummy variable equal to one if there is a free trade agreement established between China and a host country. Information on free trade agreement is derived from FTA network of Ministry of Commerce of China (MOFCOM). ${ }^{5}$

Another worthwhile point to analyse the location choice of Chinese outbound infrastructure investments is the national agglomeration effect that is driven from economic geography literature. In order to test this hypothesis, we include number of FDI projects operated by

\footnotetext{
${ }^{4}$ General government deficit is proxied by subtracting general government revenues (\% GDP) from general total government expenditures (\%GDP.) General Government revenue includes taxes, grants receivable, social contributions and other revenue. Total expenditure consists of total government expenditure and the net acquisition of nonfinancial assets. Gross national saving is gross disposable income that is left after excluding final consumption expenditure. Public debt is the gross general government debt as of GDP.

5 - See http://fta.mofcom.gov.cn/english/index.shtml
} 
Chinese firms (LagOfdi) in a host country outside of infrastructure sectors. It is expected that Chinese MNEs tend to be attracted to host countries where other Chinese FDI are concentrated for reasons discussed in section 2.3 (H6). This variable is derived from fDi Markets database.

As additional control variables, we include host country GDP $(\log G D P)$ in million USD dollars as a measure of economic size. The population weighted distance (logDist) in kilometers between China and a host country's biggest city is used as a proxy for physical distance ${ }^{6}$. Common language dummy (comLang) is included as a proxy for cultural distance. It takes the value one if at least $9 \%$ of the population of the host country and China share the same language. Both distance and common language variables are collected from CEPII database and GDP measure (based on Purchasing Power Parity) is collected from World Bank, World Development Indicators. We also control for macroeconomic stability factors in host country since foreign and private firms investing in infrastructure services are more sensitive to macroeconomic factors such as inflation, exchange rate risk, and country defaults. As a proxy for macroeconomic stability, Buckley et al., (2009) used a host country's inflation rate and suggested that stable and predictable inflation rates enable firms to make long-term corporate planning with respect to price-setting and profit expectations. High inflation also increases the cost of locally produced input goods and therefore deter investment. As an indicator of host country macroeconomic stability, we use inflation rate (cpiInf) and international reserves in US\$ (logResv). Additionally, host country official exchange rate against US\$ (logexchange) is used as a robustness check. These variables are collected from World Development Indicators. Furthermore, it's widely believed that better infrastructure promotes trade and attracts foreign direct investment (FDI). The role of infrastructure is an important issue in this paper, but is in an opposite way from traditional findings. Countries with lower infrastructure endowment are those with greater demand for infrastructure financing and hence, they are expected to be more welcoming towards foreign investment. Kirkpatrick et al., (2006) find that FDI in infrastructure is attracted to countries, where the need for additional infrastructure provision is greater. As an indicator of infrastructure quality in host countries, we use overall infrastructure quality index (infraQI) obtained from Global Competitiveness Index database of World Economic Forum. This value ranges from 1 to 7 with higher numbers indicating better infrastructure. Since we

\footnotetext{
${ }^{6}$ The distance between biggest city of the host country and Beijing is weighted by the share of the city and overall country's population (See Cepii database, http://www.cepii.fr/cepii/en/bdd_modele/bdd.asp )
} 
investigate the determinants of FDI in infrastructure services, it is logical to assume that countries with lower infrastructure quality are those with greater infrastructure needs and therefore it is expected to encourage more investments from Chinese MNEs.

\subsection{Methodology}

\subsubsection{Theoretical Background and Log of Gravity Model}

The Gravity model has widely been used in the economic literature was first initiated by Jan Tinbergen (1962). It was based on the idea that the size of trade between two countries is directly proportional to their economic size and inversely related to the geographical distance between them. In its simplest stochastic form the model can be described as follows:

$$
V_{i j}=A \frac{Y_{i}^{B_{1}} Y_{j}^{B_{2}}}{D_{i j}^{B_{3}}} \mathrm{~T}_{i j}
$$

Where $V_{i j}$ is the volume of trade between country $i$ and $j$; A is a constant; $Y_{i}$ and $Y_{j}$ is the GDP of the host country $i$ and $j$ respectively; $D_{i j}$ is the distance between two countries; $B_{1}, B_{2}, B_{3}$ are unknown parameters; $\boldsymbol{T} \boldsymbol{i} \boldsymbol{j}$ is the error term with $E(\mathrm{~T} \boldsymbol{i} \mid Y \boldsymbol{i}, Y \boldsymbol{j}, D i j)=1$.

Taking the logarithm of both sides of equation (1) the gravity model can be written as follows:

$$
\ln V_{i j}=\operatorname{Ln} A+B_{1} \ln Y_{i}+B_{2} \ln Y_{j}-B_{3} \ln D_{i j}+\ln T i j
$$

Although this log-normal specification of the gravity model has widely been used in the trade literature, several serious issues have been raised. For brevity reasons we summarize the most important ones in literature.

First as noted by Burger et al. (2009) log transformation changes the nature of the estimation process since it generates the estimates of $\ln V_{i j}$ not the estimates of $V_{i j}$. The antilogarithms of these coefficient estimates tend to be biased, which in turn may lead to under prediction of large trade flows (Flowerdew \& Aitkin, 1982). Furthermore, the real problem comes with the failure of the homoscedasticity assumption which log normal models are usually based on. As we know, consistent estimates of the parameters in equation (2) require $T \boldsymbol{i} \boldsymbol{j}$ and $\ln T \boldsymbol{i} \boldsymbol{j}$ to be statistically independent of regressors. Additionally, we also know that the expected value of a logarithm of a random variable depends both on its mean and its higher order of moments. The problem arise here relates to the fact that in the case of heteroscedasticity in the data (that the variance of the error term is the function of explanatory variables $Y_{i}, Y_{j}$ or $D_{i j}$ ), then the 
expected value of the logarithm of the error term $E(\ln \lceil\boldsymbol{i} \boldsymbol{j})$ will also depend on these regressors leading to inconsistent estimates of OLS (Silva \& Tenreyro, 2006). Therefore, even though the original error term is statistically independent of the regressors, $\left(\mathrm{T} \boldsymbol{i} \boldsymbol{j} \mid Y_{i}, Y_{j}, D_{i j}\right)=1$, the $\log$ transformation of equation (2) will change the properties of the error term and $(\ln T \boldsymbol{i} \boldsymbol{j})$ will be the function of covariates. i.e., $l\left(\mathrm{~T} \boldsymbol{i} \boldsymbol{j} \mid Y_{i}, Y_{j}, D_{i j}\right)=f\left(\mathrm{~T} \boldsymbol{i} j \mid Y_{i}, Y_{j}, D_{i j}\right) \neq$ const, violating the condition for the consistency of OLS (Silvana \& Tenreyro, 2006). To see the point more clearly, taking the expected value of the equation (2):

$$
\begin{aligned}
E\left[\ln V_{i j}\right]= & E\left[\operatorname{Ln} A+B_{1} \ln Y_{i}+B_{2} \ln Y_{j}-B_{3} \ln D_{i j}+\ln T i j\right]=E(\ln A)+B_{1} E\left(\ln Y_{i}\right)+ \\
& B_{2} E\left(\ln Y_{j}\right)-B_{3} E \ln \left(D_{i j}\right)+E(\ln T i j)
\end{aligned}
$$

the conditional distribution of $V_{i j}$ is distorted since Jensen's inequality implies that $E(\ln T \boldsymbol{i} \boldsymbol{j})$ $\neq \ln E$ (Ti $\boldsymbol{j})$. Thus, if the data is heteroscedastic (as highly probable in our context), the expected value of the error term, $E(\ln T \boldsymbol{i} \boldsymbol{j})$ will depend on the covariates and OLS will result in misleading estimates (Silva \& Tenreyro, 2006).

Another concern with the log specification relates to the transformation of dependent variable in the presence of zero values since the log of zero is undefined. This is particularly important in our context as very high percentage of the dependent variable contains zero values in our sample. Several methods have been proposed to tackle this issue. One of the common methods used to overcome this issue is omitting the zero-valued trade flows. However, as also noted by Helpman et al.(2008) dropping zero value observations as usually OLS does lead to sample selection bias that may result in inconsistent or biased estimates. An alternative method is to add a small positive constant to the dependent variable $\left(V_{i j}+\right.$ const $)$ in order the make the logarithm to be defined. This method is not also a preferred solution since the choice of the constant lacks empirical and theoretical justification (Linders \& De Groot, 2006) and even small differences on the choice of the constant can distort results significantly (Flowerdew and Aitkin, 1982). Apart from these methods, Heckman selection model (Heckman, 1979) is another alternative to deal with zero values, however we do not consider Heckman model here for the following reasons. First, to apply Heckman selection model to our gravity equation we need to separate the regression in two parts: an extensive margin which explain the relationship between positive trade volume and the explanatory variables and an intensive margin which relates the probability of engaging in trade with explanatory variables. However, the first stage requires to find at least one "instrument" (variable) that affects the probability of the two 
countries participating in trade, but shouldn't not have any influence on the size of the trade between them. Finding this over-identifying variable is not an easy task, especially in our context. In addition, Heckman sample selection model is not robust to heteroscedasticity as a bias is created by the log transformation of the outcome equation that were described above.

Accordingly, Silva and Tenreyro (2006) propose a simpler way to deal with these issues raised above. They propose the Poisson pseudo-maximum-likelihood (PPML) and assess its performance using Monte Carlo simulations. They show that in the presence of heteroscedasticity, even controlling for fixed effects the estimations based on standard methods can be biased and may produce highly misleading results. However, estimations based on PPML show that they are robust to various patterns of heteroscedasticity and provide simpler ways to deal with zeros.

\subsubsection{Empirical Specification}

Following Silva and Tenreyro (2006) (Silva \& Tenreyro, 2006), we use the Poisson pseudo maximum likelihood (PPML) technique for estimation of all regression models. The PPML estimation method is robust to different patterns of heteroscedasticity and also provides a natural way to deal with zeros in the sample. A simulation results by Silva and Tenreyro (2011) show that Poisson performs strongly even in datasets with very large numbers of zeros. Besides, PPML does not require data to follow the Poisson distribution. All required for consistency is that the conditional mean is correctly specified, i.e. $E\left[F D I_{i j, t} \mid X_{i j, t}\right]=$ $\exp \left[X_{i j, t}\right]$. Therefore, even if the conditional variance is not proportional to the conditional mean, the PPML is still consistent, hence there is no requirement of equi-dispersion as the original Poisson has (see Silva \& Tenreyro, 2006).

Thus, highly desirable properties of PPML estimator allow us to estimate the determinants of Chinese outward FDI in the following multiplicative form:

$$
\begin{aligned}
\text { FDI }_{i j, t}=\exp & \left(B_{0}+B_{1} \text { Gravity }_{j, t}+B_{2} \text { Ctrade }_{j, t}+B_{3} \text { Macrostability }_{j, t}\right. \\
& +B_{4} \text { infraindex }_{j, t}+B_{5} \text { Resources }_{j, t}+B_{6} \text { O_ChineseFDI }_{j, t} \\
& +B_{7} \text { FTA }_{j, t}+B_{8} \text { GNsaving }_{j, t}+B_{9} \text { Instituitions }_{j, t}+B_{10} \text { Govdeficit }_{j, t} \\
& \left.+B_{11} \text { Govdeficit }_{j, t} * \text { Instituitions }_{j, t}\right) \mathrm{T}_{i j, t}
\end{aligned}
$$

Where $i$ and $j$ indicates home (China) and host country respectively; $F D I_{i j, t}$ is the volume of capital investment by Chinese firms in a host country's infrastructure in year $t$; Gravity $_{j, t}$ 
includes traditional gravity variables, particularly the $\log$ GDP of host country $\left(\log G D P_{j, t}\right)$, $\log$ of distance $\left(\log\right.$ Distance $_{j}$ ) between China (Beijing) and the host country biggest city, a common language dummy (Comlang ${ }_{j}$ ) that takes value of one if at least $9 \%$ of the population of the host country and China share the same language. Ctrade $e_{j, t}$ is a measure of China's trade (exports plus imports) intensity with a host country in year $t$ expressed as a percentage

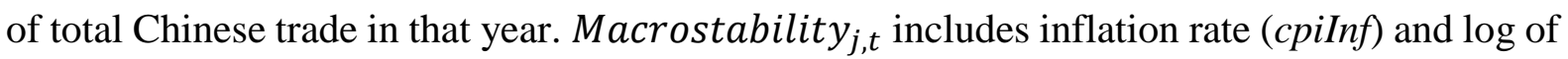
international reserves $(\log R e s v)$ as an indicator of macroeconomic stability; infraindex $_{j, t}$ is the infrastructure index that ranks the quality of overall infrastructure in a host country; Resources $_{j, t}$ is the total natural resource endowment of a host country as a percentage of its GDP; $O_{-}$ChineseFDI $I_{j, t}$ is total number of Chinese FDI projects in a host country outside of infrastructure sectors; $F T A_{j, t}$ is a dummy variable equals to one if there exists a free trade agreement between a host country and China in year $t$; GNsaving $s_{j, t}$ is the gross disposable income (gross national savings) of a host country expressed as a percentage of its GDP; Govdeficit $_{j, t}$ is general government deficit as a percentage of GDP; Instituitions $s_{j, t}$ is a proxy for institutional quality in a host country measured by the rule of law index (for alternative measures see section 2.4.2); Govdeficit $_{j, t} *$ Instituitions $_{j, t}$ is the interaction between general government deficit and institutions to test whether the effect of these variables are linked. Finally, $\mathrm{T}_{i j, t}$ is an error term with $E\left(\mathrm{~T}_{i j, t} \mid X\right)=1$, assumed to be statistically independent of regressors.

All explanatory variables are listed and defined in appendix Table 2.A2. The descriptive statistics for the main independent variables is provided in Table 2.A3

\subsection{Estimation Result}

As a first step, we look at what variables (geography, institutions, macro stability) are most useful in accounting the movements of Chinese infrastructure ODI in the presence of multicollinearity among controlling variables. Following Hastie, Tibshirani, and Friedman (2008), the least absolute shrinkage and selection operator (LASSO) estimate is defined by

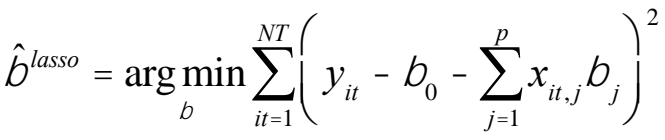

$$
\begin{aligned}
& \text { subject to }\left.\sum_{j=1}^{p}\right|_{j} \mid \leq z
\end{aligned}
$$


In the equivalent Lagrangian form

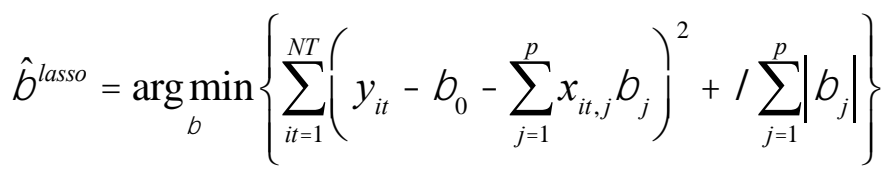

Where, is the shrinkage (regularization) factor, $y_{i t}$ the dependent variable (Chinese infrastructure ODI), and $x_{i t}$ the vector of explanatory variables (geography, institutions, and macroeconomic controls). As a preliminary to the fixed-effect estimation, this setup uses crosscountry information, covering 108 observations (countries). Figure 2.2 provides the trace plots of coefficient fit by LASSO for the full sample. For the number of projects invested, common language, bilateral trade with China, lag Chinese ODI, FTA with China, host-country size (GDP), and government deficits are the most significant in accounting for Chinese infrastructure ODI; none for the volatility adjustment. For the total value of projects invested, geographic distance from China, common language, lag Chinese ODI, FTA with China, hostcountry size (GDP), income level (GDP per capita), growth, government deficits, quality of institutions as measured by voice \& accountability index (highly correlated with rule of law, corruption, and government effectiveness measures) are the most significant in accounting for Chinese infrastructure ODI. 
Figure 2. 2 This figure provides trace plots of coefficients (standardized) on Chinese infrastructure ODI fit by LASSO for a cross section of 108 countries. The estimation use ten-fold cross validation for regularization parameters, using geography, institutions, and macroeconomic controls.
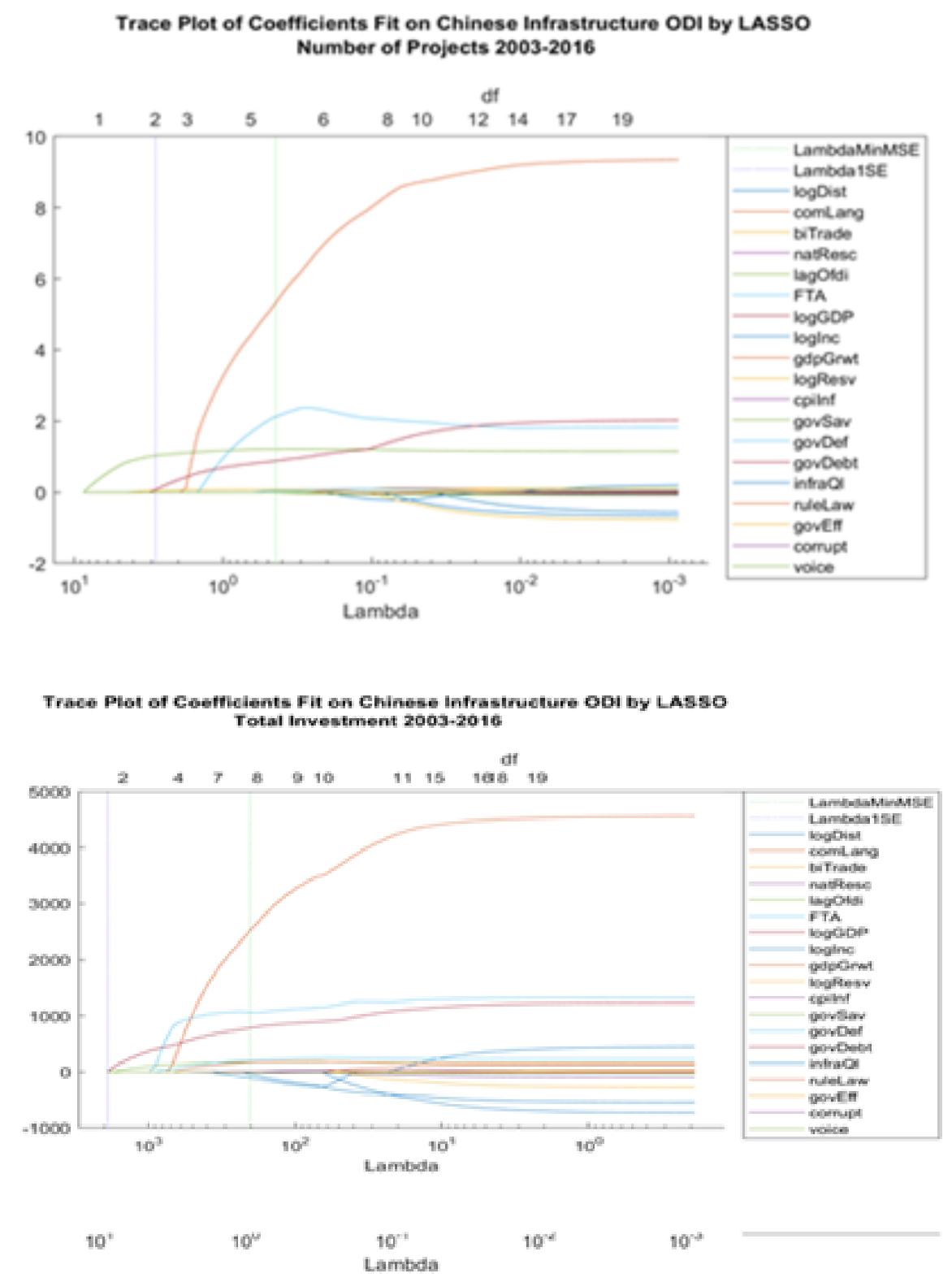

As a next step, we use Poisson Pseudo Maximum Likelihood (PPML) estimation with clustered standard errors for our main analysis. Year fixed effects are included across all regressions in order to account for time specific shocks or temporal changes in the global economy. BiTrade 
and $O f d i$ variables are lagged by one period to prevent reverse causality or endogeneity issues that may occur with inclusion of these variables. ${ }^{7}$

Table 2.3 reports estimation results for Chinese infrastructure ODI without (column1) and with interactions terms (column 2-6). Column 1 shows that gravity variables (logGDP, logDist, comLang dummy) are important determinants of Chinese ODI in infrastructure sector. Quality of overall infrastructure (infraQI) index shows a negative significant sign confirming our presumption that outbound infrastructure projects tend to be more common in countries with extra need for infrastructure services (those with poor infrastructure facilities). Surprisingly, total natural resource endowments (NatResc) do not seem a significant factor in attracting ODI (H1). We also find support for the hypothesis (H5) that a Free Trade Agreement (FTA) with a host country is a strong influential factor in attracting Chinese ODI. However, we find no significant effect of Chinese bilateral trade (BiTrade) contrary to our expectations that Chinese infrastructure investments are attracted to countries where it has stronger trade links $(\mathrm{H} 4)$. Results also shows that these investments tend to go relatively less to countries with higher national savings (those with additional source of funds available for domestic investment) as represented by a negative coefficient on govSav. Additionally, the results from column 1 show that macro stability conditions (cpiInf, logResv) do not matter for Chinese OFDI in infrastructure services. This is also in line with previous findings pointing to non-risk aversion of Chinese MNEs to host country economic instability. Given our focus, government deficit (govDef) a proxy for fiscal constraint and rule of law do not show significant relationship.

As a next step (Table 2.3, column 2) in our main specification, we add an interaction term between government deficit and rule of law in order to test whether the effect of these variables are linked (H3). In fact, adding the interaction term provide interesting results. The negative coefficient on the individual govDef term becomes statistically significant at $10 \%$ level implying that higher government deficit (positive value) deters investment.

\footnotetext{
${ }^{7}$ Other right hand side variables are lot lagged mainly because Chinese ODI is still minor to affect them and infrastructure projects usually take longer time period to reflect its effect on economy.
} 
Table 2. 3 Poisson pseudo-maximum-likelihood (PPML) estimation. Dependent variable is the total volume of investments (million USD) from China to host country $\mathrm{j}$ in year $\mathrm{t}$.

\begin{tabular}{|c|c|c|c|c|c|c|}
\hline VARIABLES & (1) & (2) & (3) & (4) & (5) & (6) \\
\hline $\operatorname{logGDP}$ & $\begin{array}{l}1.074 * * * \\
(0.212)\end{array}$ & $\begin{array}{l}1.041 * * * \\
(0.209)\end{array}$ & $\begin{array}{l}1.018 * * * \\
(0.204)\end{array}$ & $\begin{array}{l}1.016^{* * * *} \\
(0.216)\end{array}$ & $\begin{array}{l}0.994 * * * \\
(0.184)\end{array}$ & $\begin{array}{l}0.849 * * * \\
(0.176)\end{array}$ \\
\hline biTrade(lagged) & $\begin{array}{l}-0.008 \\
(0.006)\end{array}$ & $\begin{array}{l}-0.008 \\
(0.006)\end{array}$ & $\begin{array}{l}-0.008 \\
(0.006)\end{array}$ & $\begin{array}{l}-0.008 \\
(0.006)\end{array}$ & $\begin{array}{l}-0.008 \\
(0.006)\end{array}$ & $\begin{array}{l}-0.001 \\
(0.003)\end{array}$ \\
\hline $\log$ Dist & $\begin{array}{l}-0.922 * * * \\
(0.305)\end{array}$ & $\begin{array}{l}-0.912 * * * \\
(0.317)\end{array}$ & $\begin{array}{l}-0.912 * * * \\
(0.327)\end{array}$ & $\begin{array}{l}-0.880^{* * * *} \\
(0.328)\end{array}$ & $\begin{array}{l}-0.894 * * * \\
(0.311)\end{array}$ & $\begin{array}{l}-0.566 \\
(0.368)\end{array}$ \\
\hline comLang dummy & $\begin{array}{l}1.730 * * * \\
(0.429)\end{array}$ & $\begin{array}{l}1.853 * * * \\
(0.400)\end{array}$ & $\begin{array}{l}1.888 * * * \\
(0.411)\end{array}$ & $\begin{array}{l}1.917 * * * \\
(0.422)\end{array}$ & $\begin{array}{l}1.744 * * * \\
(0.473)\end{array}$ & $\begin{array}{l}1.959 * * \\
(0.776)\end{array}$ \\
\hline $\log \operatorname{Resv}$ & $\begin{array}{l}-0.180 \\
(0.109)\end{array}$ & $\begin{array}{l}-0.180 \\
(0.113)\end{array}$ & $\begin{array}{l}-0.174 \\
(0.130)\end{array}$ & $\begin{array}{l}-0.162 \\
(0.120)\end{array}$ & $\begin{array}{l}-0.148 \\
(0.112)\end{array}$ & $\begin{array}{l}-0.190 \\
(0.191)\end{array}$ \\
\hline cpiInf & $\begin{array}{l}0.001 \\
(0.030)\end{array}$ & $\begin{array}{l}0.015 \\
(0.028)\end{array}$ & $\begin{array}{l}0.014 \\
(0.029)\end{array}$ & $\begin{array}{l}0.011 \\
(0.027)\end{array}$ & $\begin{array}{l}0.001 \\
(0.026)\end{array}$ & $\begin{array}{l}0.022 \\
(0.030)\end{array}$ \\
\hline infraQI & $\begin{array}{l}-0.373 * \\
(0.204)\end{array}$ & $\begin{array}{l}-0.371 * \\
(0.209)\end{array}$ & $\begin{array}{l}-0.343 \\
(0.264)\end{array}$ & $\begin{array}{l}-0.294 \\
(0.214)\end{array}$ & $\begin{array}{l}-0.226 \\
(0.147)\end{array}$ & $\begin{array}{l}-0.953 * * * \\
(0.239)\end{array}$ \\
\hline natResc & $\begin{array}{l}0.013 \\
(0.025)\end{array}$ & $\begin{array}{l}0.002 \\
(0.028)\end{array}$ & $\begin{array}{l}-0.002 \\
(0.028)\end{array}$ & $\begin{array}{l}-0.007 \\
(0.030)\end{array}$ & $\begin{array}{l}0.003 \\
(0.028)\end{array}$ & $\begin{array}{l}0.024 \\
(0.024)\end{array}$ \\
\hline Ofdi(lagged) & $\begin{array}{l}0.017 \\
(0.012)\end{array}$ & $\begin{array}{l}0.018 \\
(0.012)\end{array}$ & $\begin{array}{l}0.020 \\
(0.012)\end{array}$ & $\begin{array}{l}0.020 \\
(0.012)\end{array}$ & $\begin{array}{l}0.021 * \\
(0.012)\end{array}$ & $\begin{array}{l}0.035 * * * \\
(0.008)\end{array}$ \\
\hline FTA & $\begin{array}{l}0.966 * * * \\
(0.315)\end{array}$ & $\begin{array}{l}0.973 * * * \\
(0.336)\end{array}$ & $\begin{array}{l}0.900 * * \\
(0.368)\end{array}$ & $\begin{array}{l}0.894 * * \\
(0.361)\end{array}$ & $\begin{array}{l}0.962 * * * \\
(0.325)\end{array}$ & $\begin{array}{l}1.864 * * * \\
(0.317)\end{array}$ \\
\hline govSav & $\begin{array}{l}-0.052 * * \\
(0.026)\end{array}$ & $\begin{array}{l}-0.048 * \\
(0.027)\end{array}$ & $\begin{array}{l}-0.047 * \\
(0.027)\end{array}$ & $\begin{array}{l}-0.044 \\
(0.027)\end{array}$ & $\begin{array}{l}-0.049 * * \\
(0.024)\end{array}$ & $\begin{array}{l}-0.058 * * \\
(0.028)\end{array}$ \\
\hline govDef & $\begin{array}{l}0.017 \\
(0.033)\end{array}$ & $\begin{array}{l}-0.090 * \\
(0.054)\end{array}$ & $\begin{array}{l}-0.103 * \\
(0.056)\end{array}$ & $\begin{array}{l}-0.088 * \\
(0.052)\end{array}$ & $\begin{array}{l}-0.050 \\
(0.055)\end{array}$ & \\
\hline rulelaw & $\begin{array}{l}0.011 \\
(0.013)\end{array}$ & $\begin{array}{l}0.006 \\
(0.014)\end{array}$ & & & & $\begin{array}{l}0.004 \\
(0.015)\end{array}$ \\
\hline rulelaw*govDef & & $\begin{array}{l}0.002 * * \\
(0.001)\end{array}$ & & & & \\
\hline goveff & & & $\begin{array}{l}0.002 \\
(0.017)\end{array}$ & & & \\
\hline goveff*govDef & & & $\begin{array}{l}0.002 * * \\
(0.001)\end{array}$ & & & \\
\hline corrupt & & & & $\begin{array}{l}-0.002 \\
(0.013)\end{array}$ & & \\
\hline $\begin{array}{l}\text { corrupt*govDef } \\
\text { continued }\end{array}$ & & & & $\begin{array}{l}0.002 * * * \\
(0.001)\end{array}$ & & \\
\hline voice & & & & & $\begin{array}{l}-0.003 \\
(0.010)\end{array}$ & \\
\hline voice*govDef & & & & & $\begin{array}{l}0.002 * \\
(0.001)\end{array}$ & \\
\hline pubdebt & & & & & & $\begin{array}{l}-0.051 * * * \\
(0.017)\end{array}$ \\
\hline rulelaw*Pubdebt & & & & & & $\begin{array}{l}0.001 * * * \\
(0.000)\end{array}$ \\
\hline Constant & $\begin{array}{l}2.939 \\
(2.586)\end{array}$ & $\begin{array}{l}3.518 \\
(2.687)\end{array}$ & $\begin{array}{l}3.838 \\
(2.798)\end{array}$ & $\begin{array}{l}3.380 \\
(2.785)\end{array}$ & $\begin{array}{l}3.481 \\
(2.738)\end{array}$ & $\begin{array}{l}4.238 \\
(3.931)\end{array}$ \\
\hline
\end{tabular}




\begin{tabular}{lllllll}
$\begin{array}{l}\text { Continued } \\
\text { Observations }\end{array}$ & 1,124 & 1,124 & 1,124 & 1,124 & 1,124 & 813 \\
Time FE & YES & YES & YES & YES & YES & YES \\
Log likelihood & -138176 & -136568 & -136382 & -136653 & -137322 & -54101 \\
Pseudo R-squared & 0.516 & 0.521 & 0.522 & 0.521 & 0.519 & 0.420 \\
\hline$* * * p<0.01, * * p<0.05, * 0<0$ & & &
\end{tabular}

*** $\mathrm{p}<0.01, * * \mathrm{p}<0.05, * \mathrm{p}<0.10$

Note: Clustered robust standard errors in parentheses.

This can be reasonable since higher fiscal deficit may increase perceived country risk and therefore may discourage foreign investment. However, the interacted term (rulelaw*govDef) shows a positive sign with a high statistical significance. This in turn, indicates that the degree of this effect, in fact, depends on level of host country institutional quality. Indeed, larger government deficit has a positive effect on FDI in countries with high level of institutional quality. That is, the stronger the institutions in a host country the higher is the positive effect of government deficit on attracting Chinese infrastructure ODI. Alternatively, the effect of institutions also depends on government deficit. The degree of the positive effect of the host country institutions is actually high in countries with larger deficit.

This leads us to think that countries with high fiscal burden cannot provide infrastructure services efficiently. Therefore, they tend to be more open towards foreign investment to fill the infrastructure investment gap as a result of their financial constraint (Etienne, Hammami, \& Ruhashyankiko, 2006). This in turn, means the higher demand for foreign investment as alternative source of funds. And when it is combined with strong institutions (effective rule of law) the effect results in more investment inflows from Chinese MNEs. For instance, in case of a developed country like UK with an average rule of law score of 93, the total effect of government deficit is $0.96 .{ }^{8}$ This implies that a percentage point increase in the share of government deficit in GDP increases Chinese infrastructure ODI by $9.6 \%$ on average.

To better express the impact of institutional quality (rule of law) on China's infrastructure ODI, we calculate the expected percentage change in China's ODI associated with an increase in country's rule of law score from its average level to the top quintile of the sample. For this purpose, we first calculate the expected percentage change in China's ODI for a unit increase in rule of law index for each country with an average level of government deficit: $\Delta y_{i}=$ 
$0.006+0.002 *$ Average Level of Gov. Deficit ${ }_{i}$ (see Table 2.3, column 2). As a next step, we calculate the difference between each country's average rule of law index and the rule of law index corresponding to the top quintile of the sample Distance $_{i}=$ Rule of law(average $)_{i}-$ Rule of law(top quintile). Finally, we multiply this value with $\Delta y_{i}$ in order to calculate the expected percentage change in China's ODI if a country's rule of law index increases from its average level to the top quintile of the sample.

Figure 2. 3 illustrates the heat map plot of expected percentage change in Chinese ODI associated with an increase in country's rule of law index from its average level to the top quintile of the sample.
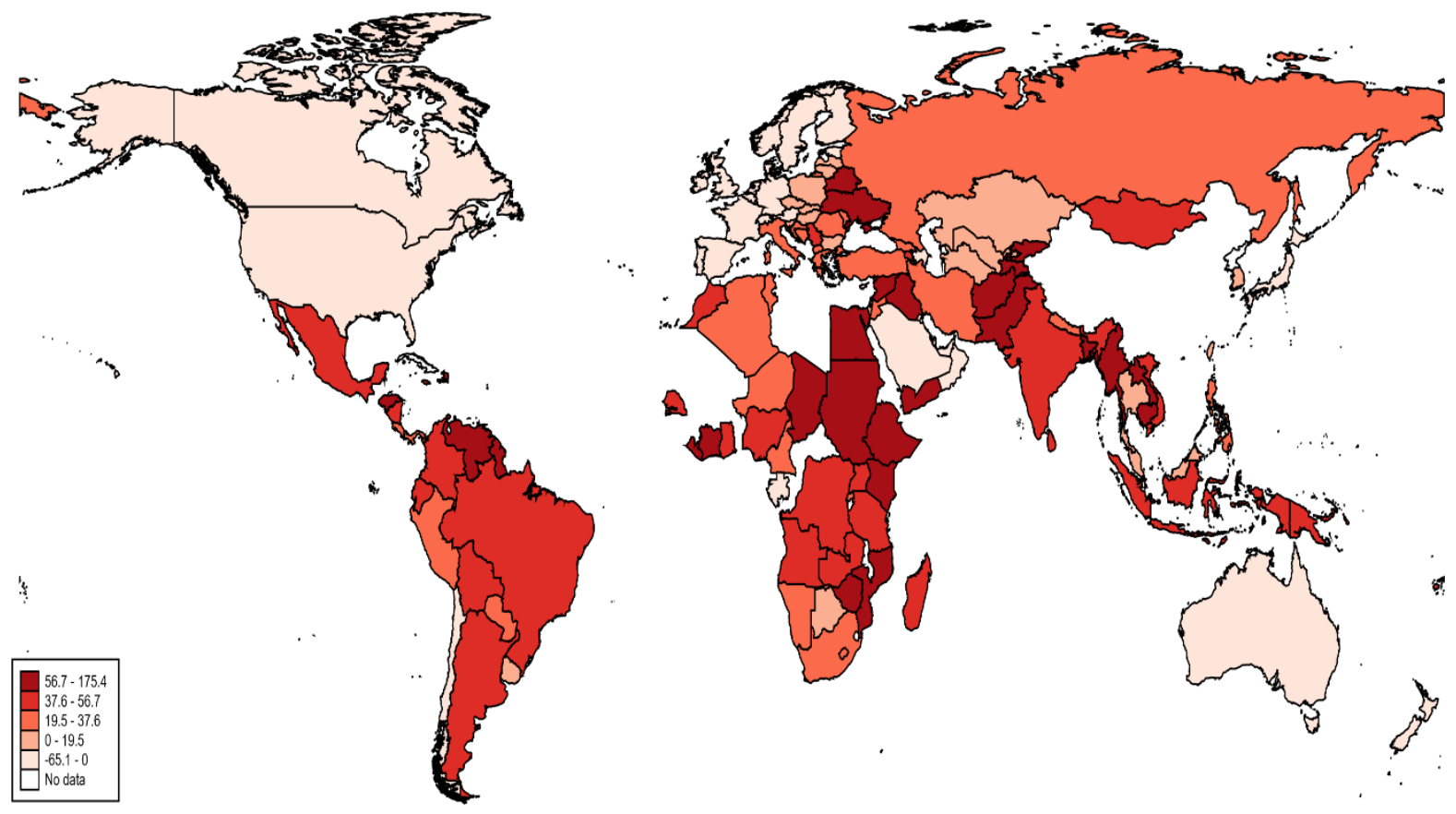

As we can see from the figure, countries that are associated with highest increase in Chinese ODI from its increase in rule of law score are those that usually have higher government deficit and very low score of rule of law index (i.e., Venezuela, Guyana in South America; Zimbabwe, Egypt, Liberia, Mozambique, Sudan in Africa; Afghanistan, Pakistan in Asia; Yemen, Iraq in Middle East; Belarus, Ukraine in Europe). On the other hand, counties that are associated with lowest increase in China's ODI from increase in its rule of law score are those that usually have higher government surplus and relatively medium level of rule of law score (mostly oil rich countries such as Saudi Arabia, UAE, Brunei, Gabon, Azerbaijan).

In the next step through column 3 to 5, we replace the rule of law variable with other proxies for the institutional quality in a host country in order to test whether this finding holds for 
different proxies. More precisely, government effectiveness (goveff), control of corruption (corrupt), voice and accountability index (voice) and their interactions are included in column 3 to 5 , respectively. The effect of these interactions are positive and statistically significant across different institutional indices and are very similar in magnitudes. In regards to the rest of the variables, overall, the sign and significance levels stay robust. Finally, in the last column public debt (pubdebt) is used as another proxy for fiscal burden and its interaction with rule of law index is included. As it is seen from column 6, the individual effect of public debt is also negative and highly statistically significant, while the rule of law index stays statistically insignificant. However, the interaction term between these variables is positive and significant at $1 \%$ level which leads to similar conclusion from the previous results. In sum, we conclude that the effect of fiscal burden on attraction of Chinese ODI depends on the level of host country institutions. Interestingly, higher government deficit leads to an increase in the provision of infrastructure services from China in countries with strong institutional environment (or vice versa).

Table 2.4 presents the results for the determinants of Chinese infrastructure ODI according to the income group of countries. For ease of comparison, column 1 repeats the estimation results for the full sample while columns 2 and 3 consider only high/upper middle income and low/lower middle income sub-samples, respectively. ${ }^{9}$ Splitting the sample into separate income groups reveals that these sets of determinants are associated with different kinds of host countries. Host country market size (logGDP) is a significant determinant in all income group of countries, whereas distance (logDist) is negative and statistically significant for the subsample of high and upper middle income group.

\footnotetext{
9 We should note that common language dummy (comlang) is dropped from the estimation in low and lower middle income sub-sample since there is no any country in this group that shares the same language with China (or that at least $9 \%$ of their population speaks Chinese language)
} 
Table 2. 4 Poisson pseudo-maximum-likelihood (PPML) estimation. Determinants of Chinese infrastructure OFDI according to income group of countries. Dependent variable is the total volume of investments (million USD) from China to host country $\mathrm{j}$ in year $\mathrm{t}$.

\begin{tabular}{|c|c|c|c|}
\hline VARIABLES & $\begin{array}{c}\text { (1) Whole } \\
\text { Sample }\end{array}$ & $\begin{array}{l}\text { (2) High and } \\
\text { Upper Middle } \\
\end{array}$ & $\begin{array}{l}\text { (3) Low and } \\
\text { Low. Middle } \\
\end{array}$ \\
\hline $\log G D P$ & $\begin{array}{c}1.041 * * * \\
(0.209)\end{array}$ & $\begin{array}{c}1.075 * * * \\
(0.347)\end{array}$ & $\begin{array}{c}1.204 * * * \\
(0.332)\end{array}$ \\
\hline biTrade(lagged) & $\begin{array}{c}-0.008 \\
(0.006)\end{array}$ & $\begin{array}{l}-0.003 \\
(0.007)\end{array}$ & $\begin{array}{l}-0.077 \\
(0.076)\end{array}$ \\
\hline $\log$ Dist & $\begin{array}{c}-0.912 * * * \\
(0.317)\end{array}$ & $\begin{array}{c}-0.806^{*} \\
(0.463)\end{array}$ & $\begin{array}{l}-0.451 \\
(0.808)\end{array}$ \\
\hline comLang dummy & $\begin{array}{c}1.853 * * * \\
(0.400)\end{array}$ & $\begin{array}{c}3.012 * * * \\
(0.455)\end{array}$ & \\
\hline $\log \operatorname{Resv}$ & $\begin{array}{l}-0.180 \\
(0.113)\end{array}$ & $\begin{array}{l}-0.258 * \\
(0.155)\end{array}$ & $\begin{array}{l}-0.409 \\
(0.406)\end{array}$ \\
\hline cpiInf & $\begin{array}{c}0.015 \\
(0.028)\end{array}$ & $\begin{array}{c}0.125 * * * \\
(0.037)\end{array}$ & $\begin{array}{c}-0.102 * \\
(0.057)\end{array}$ \\
\hline infraQI & $\begin{array}{c}-0.371^{*} \\
(0.209)\end{array}$ & $\begin{array}{c}-0.689 * \\
(0.392)\end{array}$ & $\begin{array}{c}0.504 \\
(0.385)\end{array}$ \\
\hline natResc & $\begin{array}{c}0.002 \\
(0.028)\end{array}$ & $\begin{array}{c}-0.009 \\
(0.030)\end{array}$ & $\begin{array}{c}0.026 \\
(0.067)\end{array}$ \\
\hline Ofdi(lagged) & $\begin{array}{c}0.018 \\
(0.012)\end{array}$ & $\begin{array}{c}0.002 \\
(0.008)\end{array}$ & $\begin{array}{c}0.220 * * * \\
(0.053)\end{array}$ \\
\hline FTA & $\begin{array}{c}0.973 * * * \\
(0.336)\end{array}$ & $\begin{array}{l}-0.164 \\
(0.382)\end{array}$ & $\begin{array}{c}1.555 * * \\
(0.607)\end{array}$ \\
\hline govSav & $\begin{array}{c}-0.048^{*} \\
(0.027)\end{array}$ & $\begin{array}{l}-0.020 \\
(0.035)\end{array}$ & $\begin{array}{c}-0.103 * * \\
(0.050)\end{array}$ \\
\hline govDef & $\begin{array}{c}-0.090^{*} \\
(0.054)\end{array}$ & $\begin{array}{c}-0.234 * * * \\
(0.084)\end{array}$ & $\begin{array}{l}-0.055 \\
(0.085)\end{array}$ \\
\hline rulelaw & $\begin{array}{c}0.006 \\
(0.014)\end{array}$ & $\begin{array}{c}0.024 \\
(0.022)\end{array}$ & $\begin{array}{c}0.012 \\
(0.031)\end{array}$ \\
\hline rulelaw*govDef & $\begin{array}{c}0.002 * * \\
(0.001)\end{array}$ & $\begin{array}{c}0.003 * * * \\
(0.001)\end{array}$ & $\begin{array}{c}0.001 \\
(0.004)\end{array}$ \\
\hline Constant & $\begin{array}{c}3.518 \\
(2.687)\end{array}$ & $\begin{array}{c}2.146 \\
(4.076)\end{array}$ & $\begin{array}{l}-2.700 \\
(7.283)\end{array}$ \\
\hline $\begin{array}{l}\text { Observations } \\
\text { Time FE } \\
\text { Log likelihood } \\
\text { Pseudo R-squared }\end{array}$ & $\begin{array}{c}1,124 \\
\text { YES } \\
-136568 \\
0.521\end{array}$ & $\begin{array}{c}727 \\
\text { YES } \\
-64139 \\
0.575\end{array}$ & $\begin{array}{c}397 \\
\text { YES } \\
-45804 \\
0.657\end{array}$ \\
\hline
\end{tabular}

Note: Clustered robust standard errors in parentheses: *** $\mathrm{p}<0.01, * * \mathrm{p}<0.05, * \mathrm{p}<0.10$

Note: Common language dummy (ComLang) is dropped from the estimation in column 3 due to the fact that there is not any country among the low and lower income countries that shares the same language with China

International reserves (logResv) has a negative association with Chinese OFDI in a sample of high-income countries. Furthermore, inflation (cpiInf) as a proxy for macroeconomic instability is positive and highly significant in high and upper middle income sub-sample (Table 2.4, column 2) while it has a negative impact in a sub-sample of middle and lower middle income country groups. This could be due to the fact that higher inflation among high income countries may indicate higher economic growth and therefore is more attractive to 
Chinese ODI (Buckley, et al., 2009) while it may be perceived differently in lower income countries. A proxy for overall infrastructure quality (infraQI) is negative and statistically significant in a sub-sample of high income countries.

Furthermore, among the most significant factors that attract Chinese infrastructure investments in a sub-sample of middle and lower middle income countries is the presence of other Chinese firms $(\mathrm{Ofdi})$ operating in a host country $(\mathrm{HO})$. This is consistent with the national agglomeration effect in economic geography literature suggesting that existence of national firms reduce uncertainties with foreign markets and generate positive externalities. Alternatively, it may also imply that there is a greater demand and necessity by firms for improved infrastructure facilities in these countries and therefore locations with a large number of other Chinese firms are among preferred destinations. A Free trade agreement (FTA) between China and a host country also contributes to an increase in the volume of investments in the sample of low and lower middle income countries, while this effect is not statistically significant in high and upper middle income group. It can be due to the fact that investing in a lower income country is riskier than a high income country because of political, economic and institutional factors; and therefore, countries where China has established free trade agreements are among preferred destinations ${ }^{10}$. More interestingly, the interaction term (rulelaw*govDef) is statistically significant for high/upper middle income sample while this is not the case for the lower income group. This may seem not so surprising especially when one thinks of low income countries with very weak rule of law indicators. Therefore, the combined effect of this variable with higher government deficit cannot act as an attraction factor for FDI.

We summarize our findings in Figure 2.4.1, highlighting economic significance of results for the whole sample of countries (Table 2.4, column 1).

\footnotetext{
${ }^{10}$ Noting that Free Trade Agreements are usually aimed at reducing investment barriers, risks and uncertainties for exporters and overseas investors.
} 
Figure 2.4 1 Expected percentage Change in China's ODI for a unit standard deviation increase in host country characteristics: Full sample

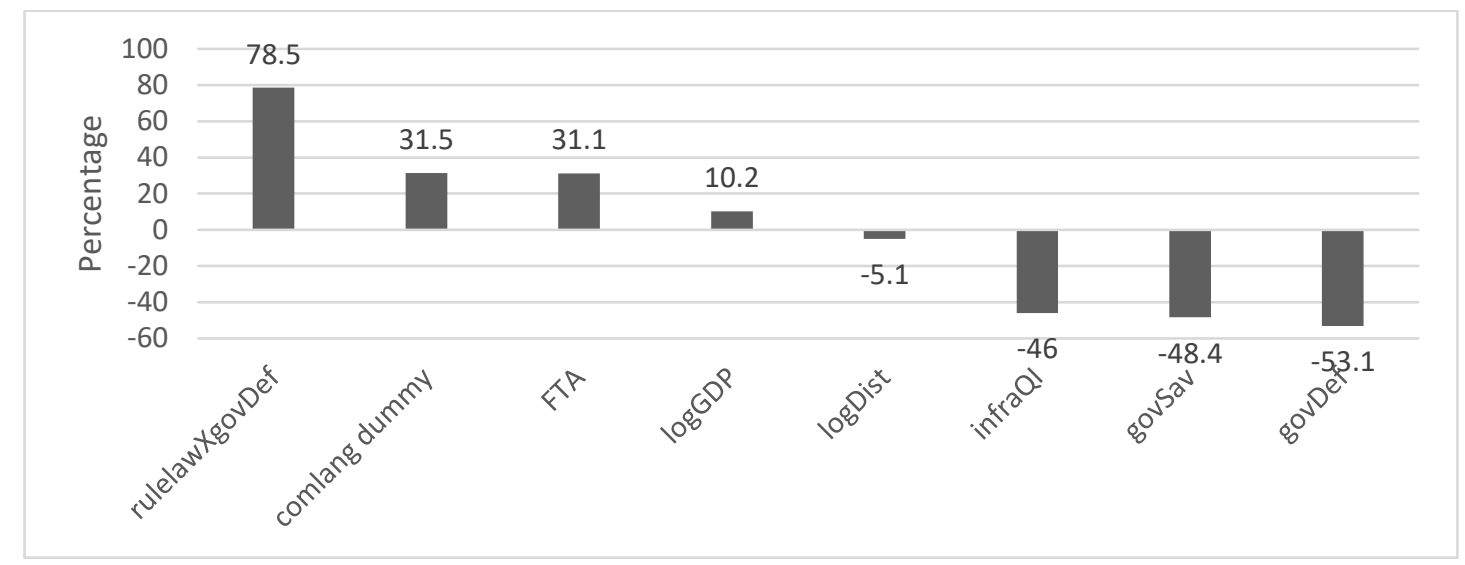

Figure 2.42 Expected percentage change in China's ODI for a unit standard deviation increase in host country characteristics: High and Upper Middle Income Group

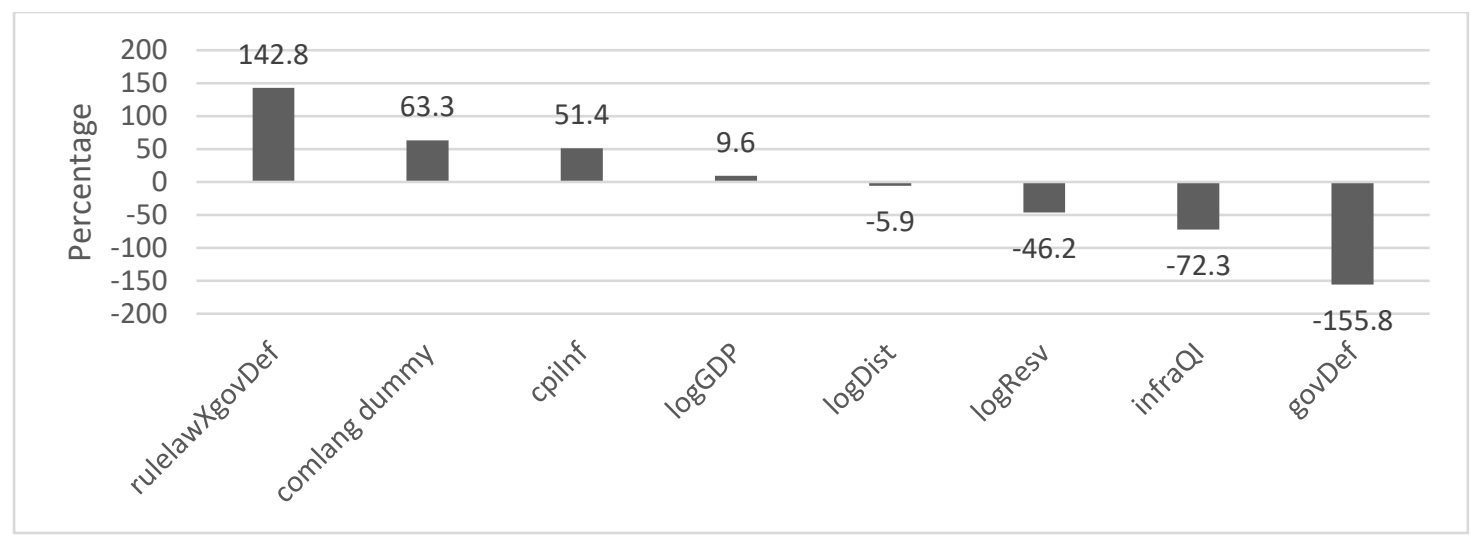

Figure 2.4 3 Expected percentage change in China's ODI for a unit standard deviation increase in host country characteristics: Lower and Lower Middle Income Group

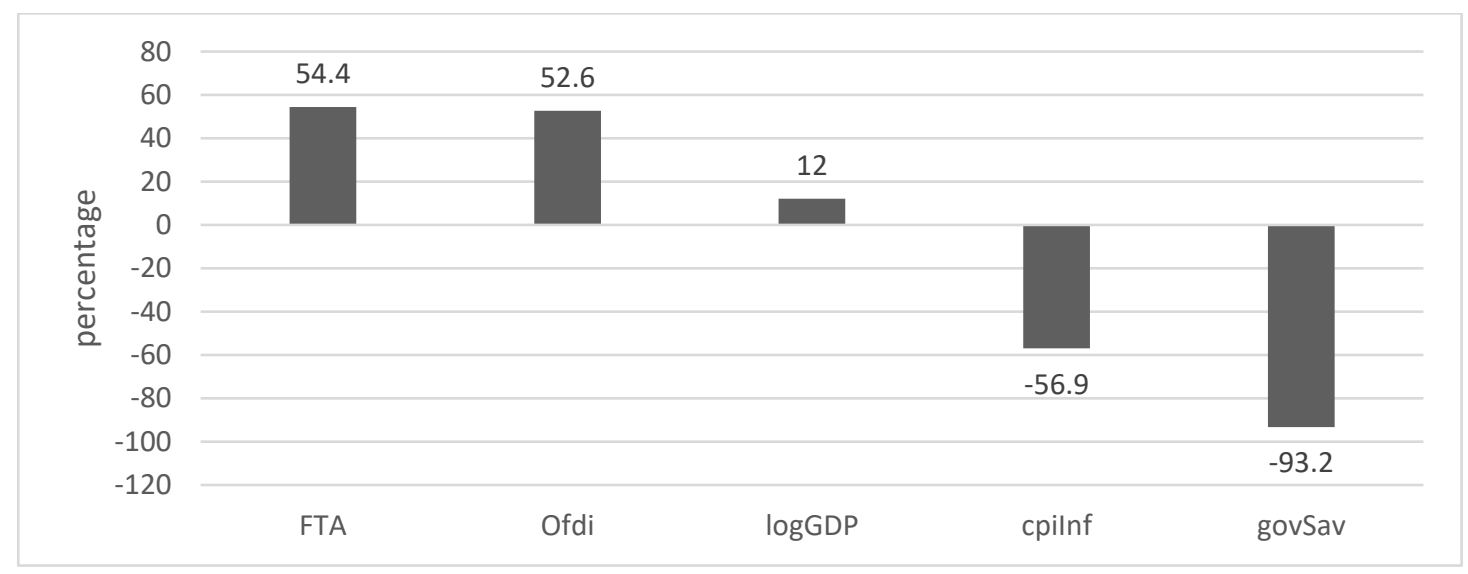


For variables with positive association with China's infrastructure ODI, interaction term (rulelaw*govDef ) has the largest economic significance (78.5\%), followed by common language indicator (comLang dummy) (31.5\%). ${ }^{11}$ For variables with negative association with China's ODI in infrastructure, government deficit (govDef) has the largest economic significance $(-53.1 \%)$, followed by government savings (govSav) $(-48.4 \%)$. We drop from calculation the variables that are statistically insignificant. Figures 2.4.2 and 4.2.3 shows the economic significance of results for high/upper middle income and low/lower middle income sub-samples respectively.

Table 2.5 reports additional robustness checks. Results are overall robust to addition and substitution of control variables. Column 1 includes additional control variables such as host country GDP per capita $(\log I n c)$ and GDP growth rate (GdpGrwt). GDP per capita appears to have a negative and weakly statistically significant impact. Interaction effect still remains positive and highly significant across all specifications. Natural resource endowment appears to be statistically insignificant (Table 2.5, Column2) when a different proxy is used as a share of oil and metal exports in total merchandise exports (Resourc/export). In column 3, host country GDP is replaced by host country population (logpopulation) as an alternative measure of a host country market size. Additionally, total bilateral trade (BiTrade) variable is disaggregated into China's exports (Cexports) and imports (Cimports) as a percentage of total Chinese exports and imports, respectively. Results are again consistent with the earlier findings that market seeking motive is an influential determinant, whereas the relationship between disaggregated trade and infrastructure investments from China is not statistically significant. In column 4, where inflation (cpiInf) is substituted by a host country exchange rates (logexchange), we find additional support that host country macro stability conditions do not matter for Chinese MNEs. Finally, further sensitivity analysis is performed by using a count dependent variable in column 5. More precisely, we derive "the number of Chinese outbound infrastructure projects" by year for each host country as a dependent variable. ${ }^{12}$

\footnotetext{
${ }^{11}$ To calculate economic significance of explanatory variables we multiply a coefficient estimate of variable with a standard deviation of a variable. For instance, economic significance of a one-standard deviation increase of the interaction term will be ccomputed as $392.45 * 0.002=0.785$

12 Number of projects are calculated from the same dataset (fdimarkets.com).
} 
Table 2. 5 Additional robustness checks. Poisson pseudo-maximum-likelihood (PPML) estimation. Dependent variable is the total volume of investments (million USD) from China to host country $\mathrm{j}$ in year $\mathrm{t}$ in columns 1 to 4. In column 5, dependent variable is the number of infrastructure projects from China to host country $\mathrm{j}$ in year $\mathrm{t}$.

\begin{tabular}{|c|c|c|c|c|c|}
\hline \multirow[b]{2}{*}{ VARIABLES } & (1) & (2) & (3) & (4) & $(5)$ \\
\hline & \multicolumn{4}{|c|}{ Capital Invested } & $\begin{array}{c}\text { Number of } \\
\text { Projects }\end{array}$ \\
\hline $\log \mathrm{GDP}$ & $\begin{array}{c}1.0507 * * * \\
(0.188)\end{array}$ & $\begin{array}{c}1.1462 * * * \\
(0.203)\end{array}$ & & $\begin{array}{c}1.3959 * * * \\
(0.176)\end{array}$ & $\begin{array}{c}0.6865 * * * \\
(0.091)\end{array}$ \\
\hline biTrade(lagged) & $\begin{array}{l}-0.0067 \\
(0.005)\end{array}$ & $\begin{array}{c}-0.0070 \\
(0.006)\end{array}$ & & $\begin{array}{c}-0.0151 * * * \\
(0.003)\end{array}$ & $\begin{array}{c}-0.0051 * * \\
(0.002)\end{array}$ \\
\hline $\log$ Dist & $\begin{array}{c}-0.7326 * * \\
(0.353)\end{array}$ & $\begin{array}{c}-1.0824 * * * \\
(0.311)\end{array}$ & $\begin{array}{c}-0.6810 * * \\
(0.265)\end{array}$ & $\begin{array}{c}-1.2132 * * * \\
(0.294)\end{array}$ & $\begin{array}{c}-0.3286 * * * \\
(0.102)\end{array}$ \\
\hline comLang dummy & $\begin{array}{c}1.7805 * * * \\
(0.342)\end{array}$ & $\begin{array}{c}1.9873 * * * \\
(0.386)\end{array}$ & $\begin{array}{c}1.7427 * * * \\
(0.299)\end{array}$ & $\begin{array}{c}1.8094 * * * \\
(0.462)\end{array}$ & $\begin{array}{c}1.1308 * * * \\
(0.266)\end{array}$ \\
\hline $\log \operatorname{Resv}$ & $\begin{array}{l}-0.1309 \\
(0.118)\end{array}$ & $\begin{array}{c}-0.2999 * * * \\
(0.111)\end{array}$ & $\begin{array}{l}-0.0949 \\
(0.113)\end{array}$ & $\begin{array}{c}-0.6453 * * * \\
(0.141)\end{array}$ & $\begin{array}{l}0.0055 \\
(0.062)\end{array}$ \\
\hline cpiInf & $\begin{array}{l}0.0126 \\
(0.030)\end{array}$ & $\begin{array}{l}0.0014 \\
(0.028)\end{array}$ & $\begin{array}{l}-0.0039 \\
(0.026)\end{array}$ & & $\begin{array}{c}0.0367 * * \\
(0.017)\end{array}$ \\
\hline infraQI & $\begin{array}{l}-0.0603 \\
(0.249)\end{array}$ & $\begin{array}{c}-0.4705^{* *} \\
(0.197)\end{array}$ & $\begin{array}{l}0.0335 \\
(0.202)\end{array}$ & $\begin{array}{l}-0.1927 \\
(0.198)\end{array}$ & $\begin{array}{l}0.0521 \\
(0.130)\end{array}$ \\
\hline natResc & $\begin{array}{l}0.0109 \\
(0.029)\end{array}$ & & & & $\begin{array}{l}-0.0113 \\
(0.015)\end{array}$ \\
\hline Ofdi(lagged) & $\begin{array}{l}0.0142 \\
(0.011)\end{array}$ & $\begin{array}{l}0.0148 \\
(0.012)\end{array}$ & $\begin{array}{l}0.0185 \\
(0.013)\end{array}$ & $\begin{array}{l}0.0109 \\
(0.015)\end{array}$ & $\begin{array}{c}0.0200 * * * \\
(0.005)\end{array}$ \\
\hline FTA dummy & $\begin{array}{c}0.9453 * * * \\
(0.311)\end{array}$ & $\begin{array}{c}0.9191 * * * \\
(0.317)\end{array}$ & $\begin{array}{c}1.0386 * * * \\
(0.273)\end{array}$ & $\begin{array}{c}0.7254 * * \\
(0.359)\end{array}$ & $\begin{array}{c}0.6350 * * * \\
(0.159)\end{array}$ \\
\hline govSav & $\begin{array}{c}-0.0639 * * \\
(0.029)\end{array}$ & $\begin{array}{c}-0.0445^{*} \\
(0.026)\end{array}$ & $\begin{array}{c}-0.0558^{*} \\
(0.029)\end{array}$ & $\begin{array}{c}-0.0306 * \\
(0.018)\end{array}$ & $\begin{array}{c}-0.0350 * * * \\
(0.013)\end{array}$ \\
\hline rulelaw & $\begin{array}{l}0.0095 \\
(0.013)\end{array}$ & $\begin{array}{l}0.0049 \\
(0.015)\end{array}$ & $\begin{array}{l}0.0117 \\
(0.015)\end{array}$ & $\begin{array}{l}0.0082 \\
(0.010)\end{array}$ & $\begin{array}{l}0.0041 \\
(0.008)\end{array}$ \\
\hline govDef & $\begin{array}{c}-0.1086^{* *} \\
(0.044)\end{array}$ & $\begin{array}{c}-0.1180 * * * \\
(0.045)\end{array}$ & $\begin{array}{c}-0.1128 * * * \\
(0.042)\end{array}$ & $\begin{array}{c}-0.1509 * * * \\
(0.036)\end{array}$ & $\begin{array}{c}-0.0799 * * \\
(0.037)\end{array}$ \\
\hline rulelaw*govDef & $\begin{array}{c}0.0018 * * \\
(0.001)\end{array}$ & $\begin{array}{c}0.0021 * * * \\
(0.001)\end{array}$ & $\begin{array}{c}0.0019 * * \\
(0.001)\end{array}$ & $\begin{array}{c}0.0024 * * * \\
(0.001)\end{array}$ & $\begin{array}{c}0.0010 * * \\
(0.000)\end{array}$ \\
\hline $\log \operatorname{Inc}$ & $\begin{array}{c}-0.5195^{*} \\
(0.294)\end{array}$ & & & & \\
\hline GdpGrwt & $\begin{array}{l}0.0507 \\
(0.036)\end{array}$ & & & & \\
\hline $\begin{array}{l}\text { Resourc/export } \\
\text { (oil\&metal) }\end{array}$ & & $\begin{array}{l}0.0028 \\
(0.009)\end{array}$ & $\begin{array}{l}0.0080 \\
(0.009)\end{array}$ & $\begin{array}{l}0.0001 \\
(0.007)\end{array}$ & \\
\hline logpopulation & & & $\begin{array}{c}0.9458 * * * \\
(0.147)\end{array}$ & & \\
\hline Cexports(lagged) & & & $\begin{array}{c}-0.0041 \\
(0.004)\end{array}$ & & \\
\hline Cimports(lagged) & & & $\begin{array}{l}0.0027 \\
(0.008)\end{array}$ & & \\
\hline logexchange & & & & $\begin{array}{l}-0.0125 \\
(0.052)\end{array}$ & \\
\hline Constant & $\begin{array}{c}4.9560^{*} \\
(2.949)\end{array}$ & $\begin{array}{c}5.4173 * * \\
(2.579)\end{array}$ & $\begin{array}{l}-4.0679 \\
(3.186)\end{array}$ & $\begin{array}{c}5.7207 * * \\
(2.323)\end{array}$ & $\begin{array}{c}-6.4842 * * * \\
(1.035)\end{array}$ \\
\hline Observations & 1,124 & 1,047 & 1,052 & 889 & 1,124 \\
\hline Time FE & YES & YES & YES & YES & YES \\
\hline Log likelihood & -133090 & -122959 & -124556 & -108881 & -660 \\
\hline Pseudo R-squared & 0.534 & 0.554 & 0.549 & 0.583 & 0.385 \\
\hline
\end{tabular}
$* * * \mathrm{p}<0.01, * * \mathrm{p}<0.05, * \mathrm{p}<0.10$

Note: Clustered robust standard errors in parentheses. 
We find overall consistent results and the interaction term is still statistically significant at $5 \%$ level with a positive value.

Inflation appears to be positive and significant similar to the case of high/upper middle income sub-sample (refer to Table 2.4, column 2). Positive coefficient on inflation may suggest that Chinese firms actually see high inflation countries as an opportunity for high returns from their investments rather than an economic constraint (Buckley, et al., 2009). Moreover, contrary to our expectations, bilateral trade variable shows a negative sign and requires further detailed analysis.

As a final note, it is also worthwhile to mention that additionally regional dummies are included in the regressions to capture potential region specific omitted variables. ${ }^{13}$ None of these regions appears to be significant and the results remain unchanged to the inclusion of these dummies. However, using fixed effects estimations shows only few significant results which is most probably due to the regressors that do not vary much over time. ${ }^{14}$

In sum, we can confirm that the findings from the main specification (Table 2.3, column 2) are overall robust to different proxies and to additional control variables. Particularly, host country market size, cultural proximity, distance, free trade agreement and the interaction term are among the most robust determinants of Chinese outbound infrastructure investments. Additionally, this study is first in finding a strong evidence that these outbound investments are attracted to countries with a combination of large government deficit and strong institutions.

\subsection{Conclusion}

This paper investigated the determinants of Chinese Outbound FDI (greenfield) in infrastructure sectors over the period 2005-2016. This is a first attempt to empirically study determinants of Chinese OFDI in this specific sector. Examining these flows of capital from world's one of the largest outbound investor country is especially important at the time when global economy suffers from large underinvestment in infrastructure. Several hypotheses are considered in this study in order to test motives behind outbound investments of Chinese

\footnotetext{
13 These region specific dummies include East Asia and Pacific, Europe and Central Asia, Latin America and the Caribbean, Middle East and North Africa, North America, South Asia, Sub-Saharan Africa.

${ }_{14}$ Results are available upon request
} 
MNEs. Mainly, gravity motives, trade links with China, host government financial constraints, the level of infrastructure and quality of institutions in host countries, endowment of natural resources and macroeconomic stability channels have been examined to identify main motivations behind China's expanding overseas investments.

This study provides interesting results. First of all, contrary to previous findings that link Chinese OFDI with weak institutions and higher political risk, results in this study suggest that this is not the case for infrastructure sectors. Instead, we find that Chinese ODI projects are attracted to countries with strong institutions and larger government deficit. It has important policy implications since governments that are in the face of scarce financial resources and strained budget constraints are indeed able to attract more infrastructure investments when there is stronger institutional environment. Moreover, we also find that while larger market size, cultural proximity, free trade agreement are the strong determinants of these outbound infrastructure projects, natural resources do not matter for Chinese ODI in this sector. 


\section{Appendix}

Table 2.A. 1 List of countries. Countries that received infrastructure FDI from China from 2003 to 2016 are marked by stars

\begin{tabular}{|c|c|c|c|}
\hline High Income & Upper Middle Income & Low Income & Lower Middle Income \\
\hline Australia** & Algeria & Afghanistan & Angola** \\
\hline Austria** & Antigua** & Bangladesh** & Armenia \\
\hline Bahrain** & Argentina** & Cambodia** & Bolivia \\
\hline Belgium** & Azerbaijan & Chad** & $\begin{array}{l}\text { Cameroon } \\
\text { Congo Rep. }\end{array}$ \\
\hline Brunei & Belarus** & Congo (DRC) & $\begin{array}{l}\text { Cote d'Ivoire (Ivory } \\
\text { Coast)** }\end{array}$ \\
\hline Canada** & Bosnia-Herzegovina** & Ethiopia** & Egypt \\
\hline Cayman Islands** & Botswana** & Haiti & Fiji \\
\hline Croatia** & Brazil** & Kenya** & Gabon \\
\hline Cyprus** & Bulgaria** & Kyrgyzstan & Georgia \\
\hline Czech Republic** & Chile** & Liberia & Ghana** \\
\hline Denmark** & China & Mozambique & Guyana \\
\hline Estonia** & Colombia** & Myanmar (Burma)** & Honduras \\
\hline Finland & Costa Rica & Nepal** & India** \\
\hline France** & Cuba & Niger & Indonesia** \\
\hline Germany** & Ecuador** & North Korea & Iraq \\
\hline Greece** & Iran & Rwanda** & $\begin{array}{l}\text { Laos** } \\
\text { Mauritius }\end{array}$ \\
\hline Hong Kong** & Jamaica** & Tajikistan** & Micronesia \\
\hline Hungary** & Jordan & Tanzania & Moldova \\
\hline Ireland** & Kazakhstan** & Uganda & Mongolia \\
\hline Israel** & $\begin{array}{l}\text { Latvia } \\
\text { Lebanon }\end{array}$ & Zimbabwe** & Morocco** \\
\hline Italy** & Lithuania** & & Nicaragua $^{* *}$ \\
\hline Japan** & Macedonia FYR & & Nigeria** \\
\hline Kuwait** & Malaysia** & & Pakistan** \\
\hline Luxembourg & Mexico & & Papua New Guinea \\
\hline $\begin{array}{l}\text { Macau** } \\
\text { Malta }\end{array}$ & Namibia & & Paraguay** \\
\hline Netherlands $* *$ & Panama** & & Philippines** \\
\hline New Zealand & Peru** & & Senegal** \\
\hline Norway & Romania** & & Sri Lanka** \\
\hline Oman & Russia** & & Sudan** \\
\hline Poland** & Serbia** & & $\begin{array}{l}\text { Syria } \\
\text { Togo }\end{array}$ \\
\hline Portugal** & South Africa** & & Turkmenistan** \\
\hline Qatar & Taiwan** & & Ukraine \\
\hline Saudi Arabia** & Thailand** & & Uzbekistan** \\
\hline Singapore** & Tunisia & & Vietnam** \\
\hline Slovakia & Turkey** & & Yemen \\
\hline Slovenia & Uruguay & & Zambia** \\
\hline South Korea** & Venezuela** & & \\
\hline Spain** & & & \\
\hline Sweden** & & & \\
\hline Switzerland** & & & \\
\hline UAE** & & & \\
\hline UK** & & & \\
\hline United States** & & & \\
\hline
\end{tabular}


Table 2.A. 2 List of variables and data source.

\begin{tabular}{|c|c|c|}
\hline Variables & Description & Source \\
\hline $\begin{array}{l}\text { fdiinfra } \\
\text { (dependent } \\
\text { variable) }\end{array}$ & $\begin{array}{l}\text { The annual amount of total FDI flows (in million US dollars) from } \\
\text { China to a host country's infrastructure }\end{array}$ & fdimarkets.com \\
\hline $\log G D P$ & Log of host country GDP & World Development Indicators \\
\hline $\log$ Dist & $\begin{array}{l}\text { Log of distance between China and a host country's biggest city } \\
\text { (population weighted distance) }\end{array}$ & CEPII \\
\hline $\begin{array}{l}\text { comLang } \\
\text { dummy }\end{array}$ & $\begin{array}{l}\text { A dummy variable that takes value of } 1 \text { if at least } 9 \% \text { population in a } \\
\text { host country speak the same language with China }\end{array}$ & CEPII \\
\hline cpiInf & Host country inflation rate & World Development Indicators \\
\hline $\log \operatorname{Resv}$ & Log of International reserve rates in a host country & World Development Indicators \\
\hline infraQI & $\begin{array}{l}\text { Quality of overall infrastructure in a host country }[1=\text { extremely } \\
\text { underdeveloped, } 7=\text { extensive and efficient }]\end{array}$ & $\begin{array}{l}\text { World Economic Forum, Global } \\
\text { Competitiveness Index }\end{array}$ \\
\hline natResc & Host country total natural resource rents as a percentage of its GDP & World Development Indicators \\
\hline biTrade & $\begin{array}{l}\text { The volume bilateral trade(exports plus imports) between China and a } \\
\text { host country divided by total Chinese trade }\end{array}$ & China Statistical Yearbook \\
\hline FTA dummy & $\begin{array}{l}\text { A dummy variable that equals to } 1 \text { if there exist a free trade agreement } \\
\text { between China and a host country in a given year }\end{array}$ & $\begin{array}{l}\text { Ministry of Commerce of PRC. } \\
\text { http://fta.mofcom.gov.cn/english/ind } \\
\text { ex.shtml }\end{array}$ \\
\hline Ofdi & $\begin{array}{l}\text { Number of FDI received by host country from the China outside of } \\
\text { infrastructure sectors }\end{array}$ & fdimarkets.com \\
\hline rulelaw & $\begin{array}{l}\text { Percentile ranking of the Rule of law index with higher values } \\
\text { indicating better institutional quality }\end{array}$ & World Governance Indicators \\
\hline govDef & Host country general government deficit as a percentage of its GDP & IMF, World Economic Outlook \\
\hline pubdebt & general gross government debt as of \%GDP & $\begin{array}{l}\text { IMF, Historical Public Debt } \\
\text { Database }\end{array}$ \\
\hline GovSav & Host country gross national savings as a percentage of its GDP & IMF, World Economic Outlook \\
\hline LogInc & Host country GDP per capita & World Development Indicators \\
\hline GdpGrwt & Host country annual GDP growth rate & World Development Indicators \\
\hline logexchange & Log of host country official exchange rate against US dollar & World Development Indicators \\
\hline logpopulation & Log of host country population & World Development Indicators \\
\hline Cexports & China's exports to the host country divided by China's total exports & China Statistical Yearbook \\
\hline Cimports & China's imports from the host country divided by China's total exports & China Statistical Yearbook \\
\hline $\begin{array}{l}\text { Resource/exp } \\
\text { ort }\end{array}$ & $\begin{array}{l}\text { fuels and ores/metals exports as a \% of host countries' total } \\
\text { merchandise exports }\end{array}$ & World Governance Indicators \\
\hline goveff & $\begin{array}{l}\text { Percentile rank of host country government effectiveness index with } \\
\text { higher values indicating better institutional quality }\end{array}$ & World Governance Indicators \\
\hline corrupt & $\begin{array}{l}\text { Control of corrupt in host country. Percentile ranked with low values } \\
\text { indicating higher corrupt }\end{array}$ & World Governance Indicators \\
\hline voice & $\begin{array}{l}\text { Voice and accountability index. Reflects perceptions which a country's } \\
\text { citizens are able to participate in selecting their government, as well as } \\
\text { freedom of expression. }\end{array}$ & World Governance Indicators \\
\hline
\end{tabular}


Table 2.A. 3 Summary Statistics

\begin{tabular}{|c|c|c|c|c|c|}
\hline Variable & Obs & Mean & Std.Dev. & Min & Max \\
\hline fdiinfra0 & 1,124 & 89.84 & 489.91 & 0.00 & $9,104.20$ \\
\hline $\log$ GDP & 1,124 & 12.13 & 1.64 & 8.05 & 16.71 \\
\hline biTrade & 1,124 & 8.39 & 20.44 & 0.01 & 149.46 \\
\hline $\log$ Dist & 1,124 & 8.94 & 0.55 & 7.06 & 9.86 \\
\hline comLang & 1,124 & 0.03 & 0.17 & 0.00 & 1.00 \\
\hline $\log \operatorname{Resv}$ & 1,124 & 9.33 & 1.87 & 3.69 & 14.05 \\
\hline cpiInf & 1,124 & 5.18 & 5.03 & -8.97 & 48.72 \\
\hline infraQI & 1,124 & 4.28 & 1.24 & 1.55 & 6.77 \\
\hline recoursegdp & 1,124 & 7.02 & 10.38 & 0.00 & 60.83 \\
\hline Ofdi & 1,124 & 2.22 & 6.08 & 0.00 & 75.00 \\
\hline FTA & 1,124 & 0.11 & 0.32 & 0.00 & 1.00 \\
\hline govSav & 1,124 & 23.95 & 10.08 & -5.73 & 64.72 \\
\hline govDef & 1,124 & 1.56 & 5.90 & -43.30 & 32.13 \\
\hline rulelaw & 1,124 & 55.58 & 28.34 & 0.94 & 100.00 \\
\hline rulelaw*govDef & 1,124 & 77.49 & 392.45 & -2900.86 & 3075.71 \\
\hline goveff & 1,124 & 58.70 & 26.83 & 0.96 & 100.00 \\
\hline corrupt & 1,124 & 54.62 & 28.98 & 2.39 & 100.00 \\
\hline voice & 1,124 & 53.86 & 27.98 & 2.84 & 100.00 \\
\hline pubdebt & 813 & 46.04 & 31.35 & 3.70 & 238.00 \\
\hline GdpGrwt & 1,124 & 3.94 & 4.25 & -14.81 & 34.50 \\
\hline GDPcap & 1,124 & $21,473.42$ & $20,877.63$ & 652.11 & $129,349.92$ \\
\hline Resource/export & 1,047 & 30.81 & 28.76 & 1.01 & 98.81 \\
\hline logpopulation & 1,124 & 16.49 & 1.48 & 13.05 & 20.99 \\
\hline Cexports & 1,124 & 0.91 & 2.51 & 0.00 & 21.42 \\
\hline Cimports & 1,124 & 0.76 & 1.85 & 0.00 & 15.21 \\
\hline logexchange & 946 & 3.08 & 2.66 & -1.31 & 9.98 \\
\hline
\end{tabular}




\title{
Chapter 3
}

\section{Why Do SMEs Not Borrow More from Banks? Evidence from Developing Asia}

\begin{abstract}
The economic slowdown following the Global Financial Crisis has brought many challenges facing small and medium-sized enterprises (SMEs) to the fore. This study examines the relationship between firm characteristics and borrowing from commercial banks by SMEs in India, Indonesia, Malaysia, the Philippines, Thailand, and Viet Nam. Analysis of microdata from enterprise surveys highlights important aspects of SME finance since the crisis, including sources of credit, lender types, and availability of collateral. The empirical analysis is done over a sample of more than 19,000 firms, with the estimation including country and industry fixed effects to address time-invariant unobserved country and industry characteristics. The estimates indicate that bank borrowing and line of credit are positively associated with financial audit, managerial experience, export participation, and ISO certificate, while it is negatively associated with foreign ownership and SME status. The findings suggest that policy implementation targeting improvement in credit guarantee systems, monitoring and credit scoring by banks particularly in developing economies where firms have relatively short-lived business registries, shortage of detailed data for credit decisions, as well as less established, limited managerial experiences, without foreign ownership and global market exposure, together with governmental intervention to overcome the limited scope and lack of collateral and legal/court system to support thereof, are potentially helpful to SME financing.
\end{abstract}




\subsection{Introduction}

Access to finance of small and medium-sized enterprises has been a contentious issue, not least since the Global Financial Crisis of 2007-2009 the major slowdown in trade, productivity, and growth has brought the challenges to the fore. The question of budget planning was brought to the fore. Bank loans are normally available at lower rates in more developed economies than in middle-income countries. Yet, banks are the main source of financing for SMEs in the developing economies: commercial banks account for $58 \%$ of their funding, of which stateowned banks supply 30\% (The Economist, 2016). Due to the lack of collateral and legal/court system to support thereof, relatively short-lived business registries resulting in shortage of detailed data for credit decisions, as well as less established and limited managerial experiences, particularly for local firms without foreign ownership and global market exposure, SMEs are typically facing challenges in borrowing from banks, leading to SMEs to the 'missing middle' in the financial system.

Further, in developing Asia, the financial system is bank-centric. In Europe, corporate debt markets have recently become an increasingly important financing channel, which could potentially benefit their SMEs down the line. In developing Asia, however, the bond markets are much less developed and thus alternatives in the financial markets might appear less accommodative. More intriguingly European banks have recently transitioned their trade finance business on to the block chain technology with a platform for SMEs to finance crossborder orders and international trade (Arnold, 2017). A better understanding of SME financing in developing Asia could pave way for new approaches in the region.

This paper deals with a pressing empirical and policy issue that has affected developing Asia since the global financial crisis - why do small and medium-sized enterprises not borrow more from commercial banks? Accounting for both demand and supply of SME financing factors, it provides evidence from micro-data in the Republic of India and five Southeast Asian economies (Indonesia, Malaysia, Philippines, Thailand, and Viet Nam).

The motivation for studying SME finance and firm characteristics related to SME financial access in this paper stems from their important contribution to economic development in Asia and the unfolding implications of the global financial crisis on financial access. The global financial crisis of 2007-2009 caused some of the worst output slowdowns and increases in unemployment inflicted on advanced and developing economies in recent decades. While the 
evidence is mixed on the effects of the global crisis on SME finance, due to the severity and cross-country linkages of the great recession, there is growing policy interest in better understanding the requirements for more inclusive economic development. The performance of SMEs, which was until recently studied as a peripheral topic in the trade, development, and finance literature, has thus gained more deserved attention. This is especially the case in Asia, where trade and production networks continue to be central to economic development, supported by intermediate inputs and labor from SMEs (Harvie, 2010; Jinjarak \& Wignaraja, 2016). As the crisis and its aftermath unfolded, it became evident that access to finance was crucial to the performance of large firms and SMEs alike, particularly for those with limited access to highly liquid capital markets and commercial bank loans. Inevitably, firms with limited access to finance tend to be perceived as less creditworthy and smaller ones like SMEs. Accordingly, our paper focusses on the issue of SME finance and the role of banks in developing Asia.

Evidence suggests that the financial gap of SMEs is large internationally. Based on statistics of the International Finance Corporation (IFC), 17 million firms (60\% of SMEs worldwide) report that their financial needs are unmet, with more than half of these ( 9 million firms) in Asia. The total global financial gap of SMEs is estimated at $\$ 1.5$ trillion- $\$ 1.8$ trillion. As Table 3.1 shows, the total credit gap and the average credit gap per enterprise are sizable in developing Asia. This financial difficulty is most widespread in Asia, where 70\% of SMEs struggle to access finance. The IFC has estimated that for the PRC and Southeast Asia the total financial gap is approximately $\$ 100$ billion, an average of $\$ 400,000$ per SME (Stein et al., 2013). 
Table 3. 1 SME Credit Gap in Developing Asia

\begin{tabular}{lcc}
\hline Economy & Total Credit Gap (\$ billion) & Average Credit Value Gap per Enterprise $(\$)$ \\
\hline Singapore & 7.1 & 166,551 \\
Brunei Darussalam & 7.2 & 333,987 \\
Hong Kong, China & 10.2 & 139,536 \\
Republic of Korea & 28.5 & 113,377 \\
Malaysia & 8.0 & 40,787 \\
PRC & 62.7 & 16,615 \\
Thailand & 11.8 & 21,474 \\
Indonesia & 11.8 & 2,112 \\
Sri Lanka & 0.1 & 16,801 \\
Philippines & 2.0 & 9,182 \\
Viet Nam & 4.3 & 6,333 \\
Lao PDR & 0.2 & 9,221 \\
India & 3.4 & 7,614 \\
Pakistan & 2.9 & 3,878 \\
Bangladesh & 1.8 & 2,888 \\
Cambodia & 0.4 & 18,676 \\
OECD Average & 14.0 & 79,595 \\
\hline
\end{tabular}

Lao PDR = Lao People's Democratic Republic, PRC = People's Republic of China, SME = small and mediumsized enterprise.

Note: "Credit gap" is the difference between formal credit provided to SMEs and total estimated potential need for formal credit based on McKinsey \& Co. estimates.

Note: OECD countries in the table include Chile, Czech Rep., Estonia, Greece, Hungary, Latvia, Mexico, Poland, Rep. of Korea, Slovakia, Slovenia and Turkey only since there are no comparable data available for other OECD countries.

Source: IFC Enterprise Finance Gap Database (2011).

To assess how SMEs' demand for financial access is underserved in developing Asia, it is also imperative to account for supply-side factors that affect SME financing. For instance, Berger and Udell (2006) point out that credit availability for SMEs is largely influenced by lending technologies (financial statement lending, small business credit scoring, asset-based lending, factoring, fixed-asset lending, leasing, relationship lending, trade credit), financial institution structure (large versus small, foreign-owned versus domestic-owned, state-owned versus privately owned, competition), and lending infrastructure (information environment; legal, judicial, bankruptcy, social, tax, and regulatory environments). The relationship between SMEs and lenders as well depends on the products and services available from the lenders, e.g. domestic and foreign commercial banks. Intriguingly, some suggest that bank lending to SMEs in many economies was not affected by the financial crisis during 2007-2009 (de la Torre, Pería, \& Schmukler, 2010). This is perhaps because the performance of SMEs in developing countries is also driven by various firm-level characteristics, including entrepreneurship, relational factors (social and production networks), and the business environment (Nichter \& Goldmark, 2009). 
The premise of our study is that a broad range of firm characteristics, of SMEs, non-SMEs, and of firms that can access finance as well as of others that are unable to, help relate the aspects of SME finance to demand and supply-side factors. We are particularly interested in four issues in SME finance. First, what is the relative importance of external finance vis-à-vis internal finance for SME and larger firms? Second, which sources of external finance do matter more for SME? Third, how are SME characteristics associated with the extent of their bank borrowing? And fourth, what is the role of collateral in bank borrowing for SMEs?

With the availability of cross-country firm-level data, notably the World Bank Enterprise Survey, several observable firm characteristics can be studied, including firm age, export participation, foreign ownership, managerial experience, financial audit, and ISO certification, among others. There are also several aspects of SME finance that can be explored in firm-level data, including, for instance, the proportion of bank borrowing in working capital, line of credit availability, type of collateral used, and type of credit and lenders. However, the firm-level data do not enable us to disentangle the influence of national-level factors on the demand and supply for SME finance.

\subsection{Literature Review and Context}

The topic of SME finance cuts across the literature on trade, development, and finance. Compared to large local firms and multinational corporations (MNCs), SMEs have more difficulty in accessing finance partly because their small size and lack of credit worthiness add to the inefficiency in credit markets due to problems of asymmetric information (Stiglitz \& Weiss, 1992). SMEs tend to face even greater difficulty in developing economies, where capital markets and regulatory frameworks are not fully developed, and financial systems tend to be dominated by banks, which is found to be associated with lower use of financial services by firms of all sizes (Beck, Demirgüç-Kunt, \& Singer, 2013). Our analysis contributes to a small but growing body of research on SME finance in developing Asia. Using data from 2005, Shen et al. (2009) found that in the PRC local proper lending authority, competition, credit schemes, and law enforcement are supportive to loan provisions by commercial banks to SMEs. Harvie et al. (2013) studied a sample of 150 questionnaires, collected in 2010 from Cambodia, Indonesia, Lao PDR, the PRC, Malaysia, the Philippines, Thailand, and Viet Nam, and found that SMEs in these developing Asian economies tend to depend on internal finance for startups and business expansion. 
Using firm-level data from Chile, Israel, Korea, Mexico, Thailand, and Turkey, Jinjarak and Wignaraja (2016) examines the export - financial constraint relationship, focusing on how SMEs differ from other firms. To analyse the relationship, they consider both the export participation (extensive margin) and the share of exports in total sales (intensive margin). Accounting for whether firms reveal that they need loans or have sufficient capital, they evaluate the association between exports and both the use of bank loans and the availability of overdraft facilities. The objective of their study is to understand better the role of finance on international trade of small firms in developing and emerging-market economies.

Our study delves further into firm-level determinants of SME finance in India, Indonesia, Malaysia, the Philippines, Thailand, and Viet Nam, using data covering more than 19,000 firms. We also attempt to draw policy implications and lessons learned on SME finance from other countries. To interpret results and draw lessons from self-assessment data, and in particular, the causality in sample, we construct a sample with each country featuring at least two survey years. Thus, our sample includes years 2005 and 2014 for India; years 2009 and 2015 for Indonesia; years 2007 and 2015 for Malaysia; years 2009 and 2015 for Philippines; years 2006 and 2016 for Thailand; years 2005, 2009 and 2015 for Viet Nam. Further, our estimation includes country and industry fixed effects to address time-invariant unobserved country and industry characteristics.

The rest of the paper is structured as follows. Section 3.3 provides descriptive analysis, covering commercial bank loans of SMEs, data, and summary statistics of our sample derived from the World Bank Enterprise Survey. Section 3.4 discusses the econometric specification and reports regression results, followed by analysis of the economic significance of firm-level determinants on SME finance based on the estimation. Policy implications and concluding remarks are provided in Section 3.5 


\subsection{Descriptive Analysis and Data}

\subsubsection{SMEs and Bank Borrowing}

Table 3.2 provides statistics on outstanding SME loans from commercial banks, as a percentage of GDP. Drawn on the IMF Financial Access Survey, the data are a useful indicator of SME finance at the country level, though observations are only available from 2004. For sample countries in this paper, data for Philippines and Viet Nam are missing altogether, while data for Malaysia and Indonesia are only available starting from 2007 and 2011, respectively. Missing data and incomplete information underline the challenges facing studies on SMEs at both the macro and the micro level. The table also provides national definitions of SMEs for the countries studied, in terms of the number of employees and alternative definitions in each country. 
Table 3. 2 Outstanding SME Loans from Commercial Banks (\% of GDP)

\begin{tabular}{|c|c|c|c|c|c|c|}
\hline Year & India & Malaysia & Thailand & Indonesia & Philippines & Viet Nam \\
\hline 2004 & 2.2 & .. & .. & .. & .. & .. \\
\hline 2005 & 2.3 & .. & 28.3 & .. & .. & .. \\
\hline 2006 & 2.4 & .. & 27.3 & .. & .. & .. \\
\hline 2007 & 2.6 & 16.8 & 25.2 & .. & .. & .. \\
\hline 2008 & 3.8 & 15.9 & 24 & .. & .. & .. \\
\hline 2009 & 4 & 17.3 & 22.3 & .. & .. & .. \\
\hline 2010 & 4.7 & 15.3 & 21.4 & .. & .. & .. \\
\hline 2011 & 5.5 & 16.3 & 23.6 & 5.9 & .. & .. \\
\hline 2012 & 5.3 & 17.9 & 24.4 & 6.1 & .. & .. \\
\hline 2013 & 6.1 & 19.3 & 26.9 & 6.4 & .. & .. \\
\hline 2014 & 6.8 & 20.2 & 27.9 & 6.4 & .. & .. \\
\hline 2015 & 7.1 & 22.3 & 28.6 & 6.4 & .. & .. \\
\hline 2016 & .. & 24.3 & 29.1 & 7 & .. & .. \\
\hline
\end{tabular}

National Definitions of an SME

\begin{tabular}{|c|c|c|c|c|c|c|}
\hline Employees & $<100$ & $<200$ & $<200$ & $<100$ & $<200$ & $<300$ \\
\hline
\end{tabular}

Alternative definition of SMEs

\begin{tabular}{ll}
\hline India & Fixed capital $<100$ mil. Indian Rupees \\
\hline Indonesia & Annual sales $<50$ bil. Indonesian Rupiah \\
\hline Malaysia & Sales turnover $<50$ mil. Malaysian Ringits \\
\hline Philippines & Assets $<100$ mil. Philippines Pesos \\
\hline Thailand & Fixed capital $<200$ mil. Thai Baht \\
\hline Viet Nam & Registered capital $<10$ bil. Vietnam Dong \\
\hline
\end{tabular}

GDP = gross domestic product, $\mathrm{PRC}=$ People's Republic of China, SME = small and medium-sized enterprise.

Source: IMF Financial Access Survey.

India: http://www.dcmsme.gov.in/ssiindia/defination_msme.htm

Indonesia: http://arno.uvt.nl/show.cgi?fid=135851

Malaysia:http://www.smecorp.gov.my/index.php/en/policies/2015-12-21-09-09-49/sme-definition

Philippines: https://dirp3.pids.gov.ph/ris/dps/pidsdps1205.pdf

Thailand: http://www.oecd.org/industry/smes/financing-smes-and-entrepreneurs-23065265.htm

Vietnam:http://www.unescap.org/sites/default/files/7\%20\%201.\%20SMEs\%20IN\%20ASIA\%0AND\%20THE\%

20PACIFIC.pdf

The data suggest that growing bank borrowing by SMEs in India increased from $2.2 \%$ of GDP in 2004 to $7.1 \%$ of GDP in 2015. SME loans from banks in Malaysia increased by $7.5 \%$ of GDP during 2007-2016 period. On the other hand, Thailand shows a U-shaped trend in SME bank borrowing; SME loans declined from $28.3 \%$ of GDP in 2005, to $21.4 \%$ in 2010, then rose again to $29.1 \%$ in 2016 . For Indonesia, SME loans from banks are only about $6 \%-7 \%$ of GDP.

The aggregate data suggest that the macro pattern of bank borrowing of SMEs differs remarkably across economies in developing Asia. The next step for the empirical analysis is to investigate how bank borrowing, line of credit availability, and important aspects of SME finance are correlated with firm-level characteristics in the sample countries. 


\subsubsection{Data}

We rely on firm-level survey data from the World Bank Enterprise Survey (WBES). The data were collected using stratified random sampling with replacement, based on face-to-face interviews and questionnaires from business owners and senior managers of firms. As our interest is on SMEs in developing Asia, we focus on the India, Indonesia, Malaysia, the Philippines, Thailand, and Viet Nam, allowing for variation in economy size and stage of economic development. Conditioning on data availability, our sample includes years 2005 and 2014 for India; 2009 and 2015 for Indonesia; 2007 and 2015 for Malaysia; 2009 and 2015 for Philippines; 2006 and 2016 for Thailand; 2005, 2009 and 2015 for Viet Nam. The data originally contained 24,652 firms for these economies, of which 11,567 are from the India, 2,764 from Indonesia, 2,418 from Malaysia, 2,661 from the Philippines, 2,043 from Thailand, and 3,199 from Viet Nam. To prepare a sample for estimation, we focus on the variables listed in Table 3.3. In our empirical analysis, we also conduct estimation for firms at various size groups, ranging from 0-25, 25-100, 100-250, and 250+ employees. 
Table 3. 3 Summary Statistic

\begin{tabular}{|c|c|c|c|c|c|}
\hline \multicolumn{6}{|l|}{ Whole Sample } \\
\hline Variable & $\mathrm{N}$ & mean & $\mathrm{sd}$ & $\min$ & $\max$ \\
\hline SME & 24,427 & 0.812 & 0.391 & 0 & 1 \\
\hline Number of employees & 24,427 & 147.4 & 542.6 & 0 & 35,824 \\
\hline Bank borrowing ( $\%$ working capital) & 23,191 & 22.65 & 30.19 & 0 & 100 \\
\hline Bank borrowing (\% new investments) & 9,156 & 25.62 & 36.07 & 0 & 100 \\
\hline Line Of credit availability & 21,180 & 0.354 & 0.478 & 0 & 1 \\
\hline Internal finance (\% working capital) & 24,100 & 63.97 & 35.93 & 0 & 100 \\
\hline Non-bank borrowing (\% working capital) & 22,835 & 1.519 & 8.428 & 0 & 100 \\
\hline Trade credit (\% working capital) & 23,080 & 7.122 & 16.69 & 0 & 100 \\
\hline Other (\% working capital) & 22,429 & 5.648 & 17.53 & 0 & 100 \\
\hline Collateral: property & 8,266 & 0.751 & 0.432 & 0 & 1 \\
\hline Collateral: equipment & 8,205 & 0.623 & 0.485 & 0 & 1 \\
\hline Collateral: account receivables & 8,088 & 0.362 & 0.481 & 0 & 1 \\
\hline Collateral: personal assets & 8,047 & 0.345 & 0.475 & 0 & 1 \\
\hline Lender: private commercial banks & 5,791 & 0.422 & 0.494 & 0 & 1 \\
\hline Lender: state-owned banks & 5,791 & 0.544 & 0.498 & 0 & 1 \\
\hline Lender:Non-bank instituitions & 5,791 & 0.0243 & 0.154 & 0 & 1 \\
\hline Lender: Other & 5,791 & 0.00898 & 0.0943 & 0 & 1 \\
\hline Firm_age & 24,416 & 18.17 & 13.03 & 0 & 161 \\
\hline Foreign ownership $(\%)$ & 24,178 & 6.342 & 22.31 & 0 & 100 \\
\hline Manager experience $(\%)$ & 23,754 & 14.08 & 9.734 & 0 & 100 \\
\hline ISO certificate & 24,090 & 0.324 & 0.468 & 0 & 1 \\
\hline $\operatorname{Exports}(\%)$ & 24,049 & 11.68 & 27.84 & 0 & 100 \\
\hline $\begin{array}{l}\text { Financial audit } \\
\text { continued }\end{array}$ & 23,047 & 0.666 & 0.472 & 0 & 1 \\
\hline \multicolumn{6}{|l|}{ SME Only } \\
\hline Variable & $\mathrm{N}$ & mean & $\mathrm{sd}$ & $\min$ & $\max$ \\
\hline SME & 19,828 & 1 & 0 & 1 & 1 \\
\hline Number of employees & 19,828 & 40.42 & 44.81 & 0 & 300 \\
\hline Bank borrowing ( $\%$ working capital) & 18,745 & 20.93 & 29.48 & 0 & 100 \\
\hline Bank borrowing (\% new investments) & 6,855 & 23.90 & 35.30 & 0 & 100 \\
\hline Line Of credit availability & 17,181 & 0.334 & 0.472 & 0 & 1 \\
\hline Internal finance (\% working capital) & 19,422 & 65.50 & 35.68 & 0 & 100 \\
\hline Non-bank borrowing (\% working capital) & 18,488 & 1.384 & 8.015 & 0 & 100 \\
\hline Trade credit (\% working capital) & 18,663 & 6.997 & 16.64 & 0 & 100 \\
\hline Other (\% working capital) & 18,217 & 5.938 & 18.09 & 0 & 100 \\
\hline Collateral: property & 6322 & 0.742 & 0.437 & 0 & 1 \\
\hline Collateral: equipment & 6,276 & 0.591 & 0.492 & 0 & 1 \\
\hline Collateral: account receivables & 6,186 & 0.336 & 0.472 & 0 & 1 \\
\hline Collateral: personal assets & 6,167 & 0.365 & 0.481 & 0 & 1 \\
\hline Lender: private commercial banks & 4,513 & 0.422 & 0.494 & 0 & 1 \\
\hline Lender: state-owned banks & 4,513 & 0.541 & 0.498 & 0 & 1 \\
\hline Lender:Non-bank instituitions & 4,513 & 0.0277 & 0.164 & 0 & 1 \\
\hline Lender: Other & 4,513 & 0.00953 & 0.0972 & 0 & 1 \\
\hline Firm_age & 19,663 & 17.32 & 12.31 & 0 & 161 \\
\hline Foreign ownership $(\%)$ & 19,463 & 4.697 & 19.46 & 0 & 100 \\
\hline Manager experience(\%) & 19,063 & 14.02 & 9.776 & 0 & 100 \\
\hline ISO certificate & 19,339 & 0.247 & 0.431 & 0 & 1 \\
\hline Exports $(\%)$ & 19,416 & 8.173 & 23.81 & 0 & 100 \\
\hline Financial audit & 18,581 & 0.634 & 0.482 & 0 & 1 \\
\hline
\end{tabular}

SME = small and medium-sized enterprise. Note: This table provides summary statistics of firm-level variables for the whole sample (top) and a subsample of SMEs only (bottom).

Source: Authors' calculations on World Bank Enterprise Survey (WBES) data. 
To visualize the comparison, Figure 3.1 highlights key differences in firm characteristics between SME and non-SME samples.

Figure 3. 1 Summary statistics. Comparison of mean values of variables for SME and Non-SME sub-samples.

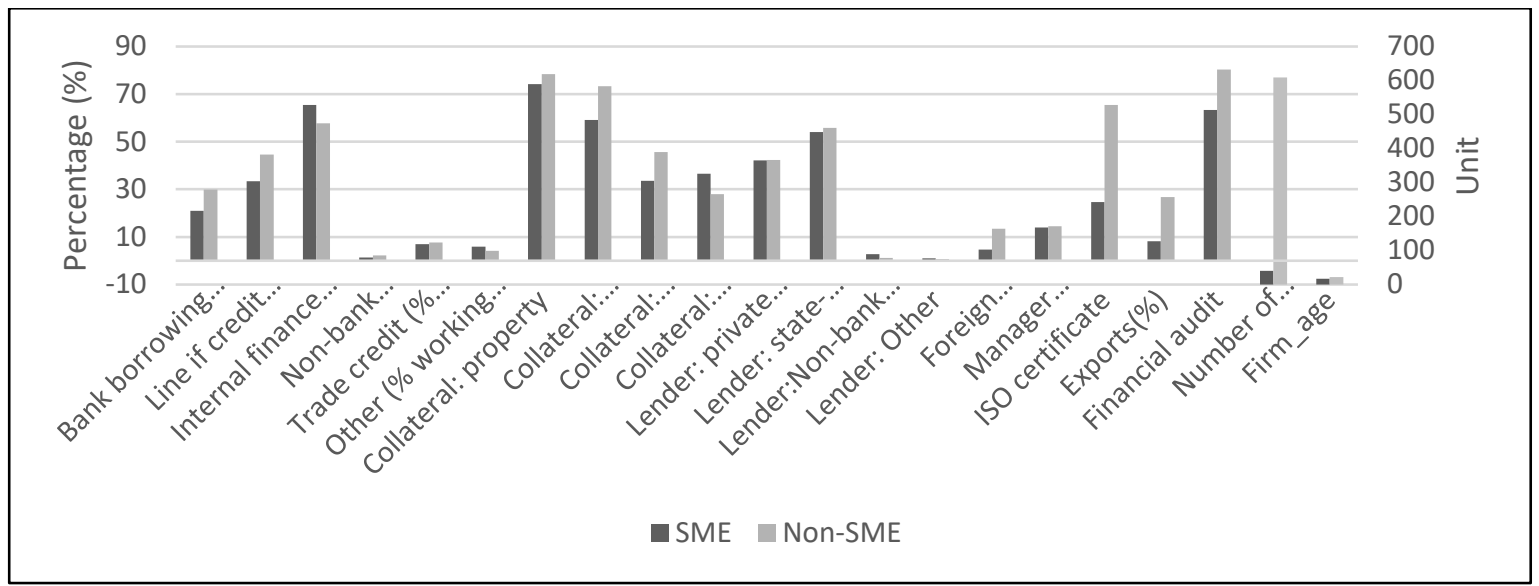

SME $=$ small and medium-sized enterprise

Source: Authors' calculations on World Bank Enterprise Survey (WBES) data.

SMEs have an average size of 40 employees; in contrast, the average is 147 employees for the whole sample (and 608 employees in a non-SME subsample). The summary statistics suggest that average bank borrowing as percentage of working capital for SMEs is about $2 \%$ lower than the whole sample average (and 9\% lower than the non-SME subsample). Additionally, for the SME subsample, $33 \%$ has line of credit availability, lower than the $35 \%$ for the whole sample (and $45 \%$ in the non-SME subsample). SMEs also appear to depend more on internal finance, use more personal assets as a collateral, export much less as a percentage of total sales, have lower foreign ownership, and less likely to have financial audit or ISO certification.

\subsection{Estimation Analysis}

\subsubsection{Econometric Specification}

We specify the dependent variable, $y_{i t}$, as a function of firm characteristics, $X_{i t}$ :

$$
y_{i t}=X_{i t}^{\prime} b+e_{i t}
$$

where $i$ denotes a firm; $t$ the year; $y$ the dependent variable; $X$ a set of firm characteristics; $b$ the coefficient estimate; and $e$ the error term. We use two measures as our main dependent variable: (1) a continuous-value variable for type of financing as a percentage of working capital (internal finance, external finance, and trade credit) and (2) a dummy variable for line 
of credit availability. Additionally, to allow for various aspects of financial access, for dependent variable $(y)$, we also use a dummy variable for lender type (private commercial banks, state-owned banks, non-bank financial institutions, and others), a dummy variable for collateral type (property and equipment, account receivables, and personal assets).

For continuous-value dependent variables (type of financing as a percentage of working capital), we use OLS estimation in the following form:

$\frac{\text { Bank Borrowing }}{\text { Working Capital }}=f\left(\begin{array}{c}\text { Firm Age, Export Participation, Foreign Ownership, } \\ \text { Managerial Experience, Financial Audit, ISO Certification, } \\ \text { Country, Industry and Year Fixed Effects }\end{array}\right)$

For dummy-variable dependent variables (line of credit availability, lender type, and collateral type), we use a Probit estimation:

\section{Probability (Line of Credit Availability) \\ $=f\left(\begin{array}{c}\text { Firm Age, Export Participation, Foreign Ownership, } \\ \text { Managerial Experience, Financial Audit, ISO Certification, } \\ \text { Country, Industry and Year Fixed Effects }\end{array}\right)$}

We run the estimations separately for firms of different sizes and countries, in addition to estimation on the whole sample of firms. Our baseline specifications pool the firm observations from all six countries in order to maximize the sample size and variation of firm characteristics in the data. For robustness checks, we also use a continuous-value variable for bank borrowing as a percentage of new investments, provide the estimates from regressions that disaggregate the firm observations by firm size and country. These alternative configurations and battery of results help us to verify the supportive evidence on the influence of firm characteristics based on data and estimation, and also derive economic significance of the determinant variables for policy implications on SME finance subsequently. 


\subsubsection{Estimation Results}

This section provides micro-level evidence on the four issues concerning the relationship between firm characteristics and borrowing from commercial banks being studied in this paper: (1) What is the relative importance of internal versus external finance for SMEs? (2) Which sources of external finance matter more for SMEs? (3) What is the link between SME characteristics and bank borrowing? (4) What is the role of collateral in bank borrowing by SMEs?

\section{Credit Type}

Table 3.4 column 1 provides coefficient estimates for a Probit estimation using a dummy variable for line of credit availability. A first noticeable pattern is that the effects of firm characteristics on internal financing are opposite to the effects of firm characteristics on line of credit availability and bank borrowing. SMEs use more internal finance and are less likely to have credit lines and other forms of credit; older firms are associated with more use of trade credit and are more likely to have a credit line; export-oriented firms use less internal finance and trade credit and are more likely to use lines of credit and external borrowing; foreignowned firms are associated with more use of internal financing and less likely to have external borrowing; firms with more experienced managers and firms with financial audit tend to use more lines of credit and bank borrowing; having an ISO certification are associated with higher probability of using credit line and bank borrowing. The results are consistent with data on the sources of finance for investment projects of SMEs in developing Asia, shown in Figure 3.2.

Before proceeding to the next estimation results, it is important to note that our estimation model may suffer from endogeneity problem (i.e., omitted variable bias, reverse causality). We mitigate omitted variable problem by including country and industry fixed effects, and also testing for the differential relationship between access to external finance and firm characteristics at each individual country level as well as at different levels of firm sizes (Table 3.5 and Table 3.7, respectively). Nevertheless, reverse causality can be an issue since firms with better access to finance are also more likely to grow faster, export more and attract better management, etc.. This issue could be mitigated by lagging right hand side variables (RHS) rather than using the current levels. However, most countries in our sample are observed for only two years and thus using lagged values instead of the current levels wouldn't allow us to utilize fixed effects and will reduce the sample size almost by half. On the positive side, once 
the new data available for these countries by WBES, we would be able to use lagged RHS variables at least partially to reduce the simultaneity issue. Another option would be to use an instrumental variable (IV) technique. However, in our case we find it challenging to suggest a reliable instrumental variable that satisfies IV conditions $(\operatorname{Cov}(X, Z) \neq 0 \& \operatorname{Cov}(Z, U)=$ 0 , where $Z$ is an IV and $U$ is an error term). For this reason, we do not interpret our findings as causal relationships.

Table 3. 4 Credit Type (\% of working capital)

\begin{tabular}{|c|c|c|c|c|c|}
\hline \multirow[b]{2}{*}{$\mathrm{Y}=$ Credit Used } & \multirow{2}{*}{$\begin{array}{l}\text { Probit: } \\
\text { Line of credit } \\
\text { availability }\end{array}$} & \multicolumn{4}{|l|}{ OLS } \\
\hline & & $\begin{array}{l}\% \text { Bank } \\
\text { borrowing }\end{array}$ & $\begin{array}{l}\text { \% Non-Bank } \\
\text { borrowing }\end{array}$ & $\begin{array}{l}\text { \% Internal Finance } \\
\text { (internal funds and } \\
\text { retained earnings) }\end{array}$ & $\begin{array}{l}\% \text { Trade } \\
\text { Credit }\end{array}$ \\
\hline SME & $\begin{array}{l}-.2319 * * * \\
(.027)\end{array}$ & $\begin{array}{l}-5.7403 * * * \\
(.600)\end{array}$ & $\begin{array}{l}-.4504 * * \\
(.182)\end{array}$ & $\begin{array}{l}4.8109 \text { *** } \\
(.660)\end{array}$ & $\begin{array}{l}-.8427 * * * \\
(.322)\end{array}$ \\
\hline Firm_age & $\begin{array}{l}.0028 * * * \\
(.001)\end{array}$ & $\begin{array}{l}-.0252 \\
(.018)\end{array}$ & $\begin{array}{l}.0030 \\
(.005)\end{array}$ & $\begin{array}{l}.0024 \\
(.020)\end{array}$ & $\begin{array}{l}.0201 * * \\
(.010)\end{array}$ \\
\hline Exports $(\%)$ & $\begin{array}{l}.0024 * * * \\
(.000)\end{array}$ & $\begin{array}{l}.0716^{* * * *} \\
(.009)\end{array}$ & $\begin{array}{l}.0077 * * * \\
(.003)\end{array}$ & $\begin{array}{l}-.0682 * * * \\
(.010)\end{array}$ & $\begin{array}{l}-.0079 * \\
(.005)\end{array}$ \\
\hline $\begin{array}{l}\text { Foreign } \\
\text { ownership }(\%)\end{array}$ & $\begin{array}{l}-.0053 * * * \\
(.001)\end{array}$ & $\begin{array}{l}-.1347^{* * * *} \\
(.010)\end{array}$ & $\begin{array}{l}-.0080 * * * \\
(.003)\end{array}$ & $\begin{array}{l}.1175^{* * * *} \\
(.013)\end{array}$ & $\begin{array}{l}.0037 \\
(.007)\end{array}$ \\
\hline $\begin{array}{l}\text { Manager } \\
\text { experience }(\%)\end{array}$ & $\begin{array}{c}.0067 * * * \\
(.001)\end{array}$ & $\begin{array}{l}.0773 * * * \\
(.023)\end{array}$ & $\begin{array}{l}-.0132 * * \\
(.006)\end{array}$ & $\begin{array}{l}-.0145 \\
(.027)\end{array}$ & $\begin{array}{l}-.0301 * * \\
(.013)\end{array}$ \\
\hline Financial audit & $\begin{array}{l}.4540 * * * \\
(.026)\end{array}$ & $\begin{array}{l}8.5414 * * * \\
(.509)\end{array}$ & $\begin{array}{l}-.4131 * * \\
(.168)\end{array}$ & $\begin{array}{l}-5.0092 * * * \\
(.598)\end{array}$ & $\begin{array}{l}-.9637 * * * \\
(.341)\end{array}$ \\
\hline ISO certificate & $\begin{array}{l}.0878 * * * \\
(.023)\end{array}$ & $\begin{array}{l}3.0414 * * * \\
(.516)\end{array}$ & $\begin{array}{l}.1218 \\
(.140)\end{array}$ & $\begin{array}{l}-1.1797 * * \\
(.562)\end{array}$ & $\begin{array}{l}-1.0554 * * * \\
(.272)\end{array}$ \\
\hline Constant & $\begin{array}{l}.0863 \\
(.227)\end{array}$ & $\begin{array}{l}40.7996 * * * \\
(1.438)\end{array}$ & $\begin{array}{l}8.1183 * * * \\
(.639)\end{array}$ & $\begin{array}{l}58.8623 * * * \\
(1.879)\end{array}$ & $\begin{array}{l}.2002 \\
(1.023)\end{array}$ \\
\hline Observations & 19,808 & 19,879 & 19,527 & 20,333 & 19,582 \\
\hline R-squared & & .139 & .031 & .165 & .022 \\
\hline Time FE & YES & YES & YES & YES & YES \\
\hline Country FE & YES & YES & YES & YES & YES \\
\hline Industry FE & YES & YES & YES & YES & YES \\
\hline $\begin{array}{l}\text { Log likelihood } \\
\text { Pseudo R-squared }\end{array}$ & $\begin{array}{l}-11838 \\
.0818\end{array}$ & & & & \\
\hline
\end{tabular}

$\mathrm{SME}=$ small and medium-sized enterprise

Note: This table reports regression results of line of credit availability (dummy dependent variable) and credit type (continuous dependent variable) on firm characteristics (control variables) for firms at different sizes. The analysis pools firm observations across India, Malaysia, Thailand, Indonesia, Philippines, and Viet Nam. Robust standard errors are in parentheses; $* * *(* *, *)$ denotes statistical significance at the $1 \%(5 \%, 10 \%)$ level.

Source: Authors' calculations using World Bank Enterprise Survey data. 
Figure 3. 2 Sources of Finance for Investment Projects of SMEs in Developing Asia

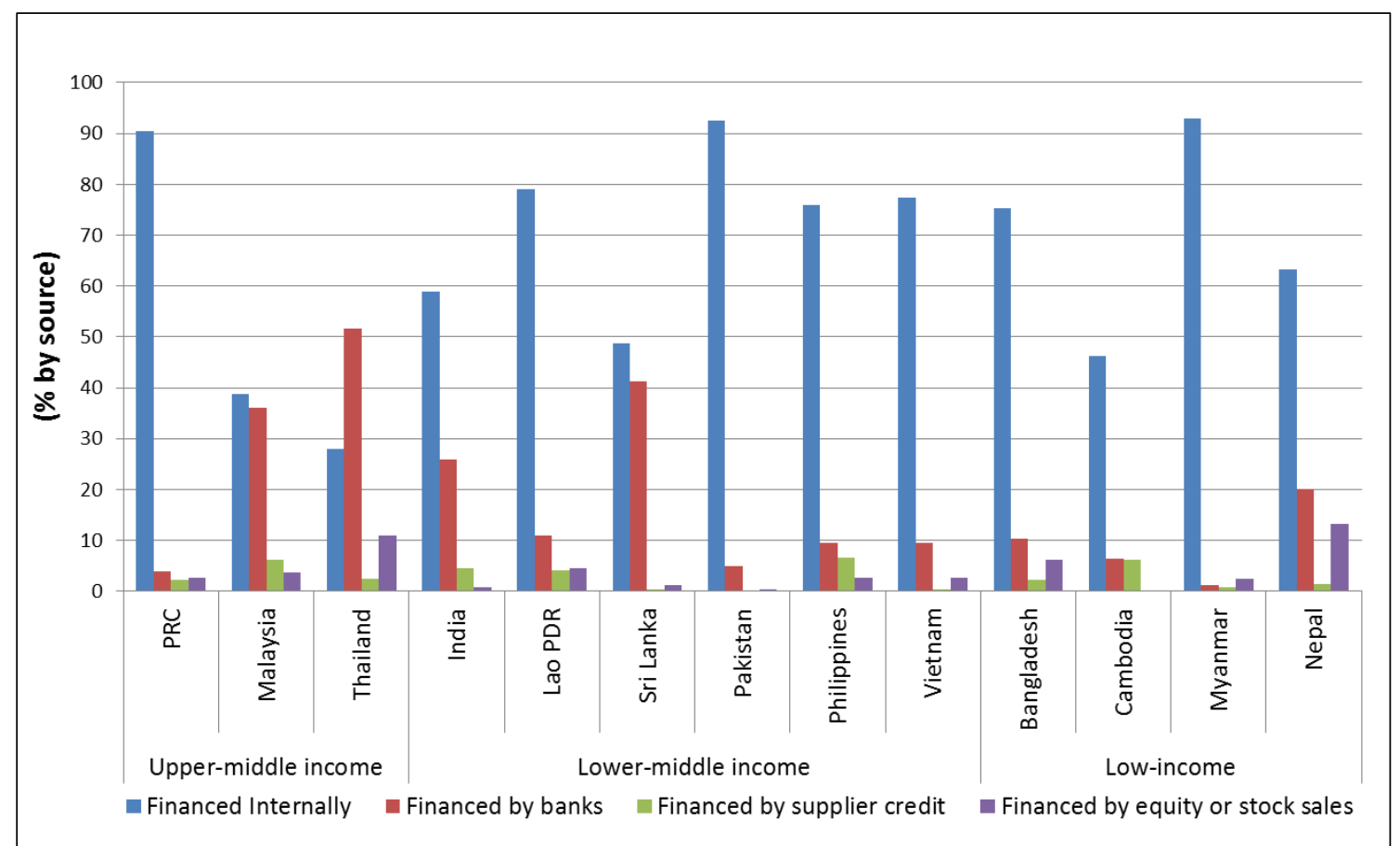

Lao PDR = Lao People's Democratic Republic, PRC = People's Republic of China, SME = small and mediumsized enterprise.

Note: Note: SMEs are defined as firms with fewer than 100 employees in India and Indonesia, firms with less than 200 employees in Malaysia, Philippines and Thailand; firms with less than 300 employees in Vietnam; use the most recently available data.

Source: Author's calculations using World Bank Enterprise Survey data.

\section{Bank borrowing (\% working capital). Country-Specific Results}

As a next step we provide country-specific results, along with results using a pooled countries sample in Table 3.5. Results shows different patterns across counties. SME status has a consistent negative and statistically significant influence on bank borrowing in India, Indonesia and Viet Nam. However, the association between bank borrowing and SME status is positive and statistically significant for Malaysia. Older firms tend to borrow more from banks in Indonesia, Thailand and Viet Nam, while in India firm age is negatively linked to bank borrowing. Additionally, we find that managerial experience is positively linked to bank borrowing in India, while surprisingly this relationship is negative in case of Thailand. The contrasting findings between Thailand and India may suggest that it is the managerial experience that considered important by banks for lending in India, not the firm age, while the opposite is true in the case of Thailand. These findings could be due to the fact that old SME sector is a reflection of inefficient and unproductive firms in India (The Economic Times, 2013) and banks may place more trust in those firms with substantial managerial experience. The use 
of managerial experience as signals for borrowers' quality by Indian banks is somewhat comparable to the findings by Barth et al.,(2009) suggesting that banks rely mostly on information on the owner rather than firm itself and can significantly reduce the loan processing cost.

Export participation has a positive association with bank borrowing in all countries in our sample, except Malaysia and Philippines although not statistically significant. Foreign ownership is negatively related to bank borrowing in Malaysia, Philippines and Vietnam. Financial audit and ISO certificate mostly have positive and statistically significant impact on bank borrowing.

Heterogeneous relationship across countries might point out to differences in the development of financial markets or explicit policies to improve financing for SMEs. For example, the Malaysian government has introduced several programmes and institutional support to promote SME development. The credit guarantee schemes by the Credit Guarantee Corporation Malaysia Berhad (CGC) are established to provide guarantee cover between 30 to 100 per cent of the loan amount for Malaysian SMEs (Rasiah \& Thangiah, 2017). The Credit Bureau of Malaysia was established to provide credible credit information and ratings of SMEs in the country and to maintain and enhance their credit ratings and thereby, facilitate their access to financing. In addition, National SME Development Council (NSDC), the SME Corporation Malaysia and SME Masterplan were launched with the aim to enhance the contribution of SMEs to Malaysia's economic development. Furthermore, Malaysian government introduced the SME Info Portal to provide information on all programmes available for these firms, such as: access to finance; markets; infrastructure; technology; and advisory services and information. Other incentives such as such as finance, tax exemption and prioritized participation in Government procurement programmes are offered to innovative SMEs to support their development. Our results suggest that these policies targeting SMEs were indeed successful to ease their access to finance and Malaysian firms stand out as an exception in our sample in regards to their access to bank borrowing. 
Table 3. 5 Country-Specific Results. Bank Borrowing (\% working capital)

\begin{tabular}{|c|c|c|c|c|c|c|c|}
\hline $\begin{array}{l}\mathrm{Y}=\text { Bank Borrowing (\% } \\
\text { working capital) }\end{array}$ & All & India & Indonesia & Malaysia & Philippines & Thailand & Viet Nam \\
\hline SME & $\begin{array}{l}-5.740 * * * \\
(.600)\end{array}$ & $\begin{array}{l}-7.888 * * * \\
(.836)\end{array}$ & $\begin{array}{l}-3.234 * * * \\
(1.102)\end{array}$ & $\begin{array}{l}5.024 * * \\
(2.085)\end{array}$ & $\begin{array}{l}-1.774 \\
(1.571)\end{array}$ & $\begin{array}{l}1.822 \\
(4.524)\end{array}$ & $\begin{array}{l}-6.181 * * * \\
(1.934)\end{array}$ \\
\hline Firm_age & $\begin{array}{l}-.025 \\
(.018)\end{array}$ & $\begin{array}{l}-.105 * * * \\
(.024)\end{array}$ & $\begin{array}{l}.087 * * \\
(.038)\end{array}$ & $\begin{array}{l}.138 \\
(.096)\end{array}$ & $\begin{array}{l}-.009 \\
(.033)\end{array}$ & $\begin{array}{l}.409 * * * \\
(.148)\end{array}$ & $\begin{array}{l}.177 * * * \\
(.059)\end{array}$ \\
\hline $\operatorname{Exports}(\%)$ & $\begin{array}{l}.072 * * * \\
(.009)\end{array}$ & $\begin{array}{l}.092 * * * \\
(.015)\end{array}$ & $\begin{array}{l}.053 * * * \\
(.020)\end{array}$ & $\begin{array}{l}-.048 \\
(.036)\end{array}$ & $\begin{array}{l}-.001 \\
(.017)\end{array}$ & $\begin{array}{l}.184 * * * \\
(.058)\end{array}$ & $\begin{array}{l}.083 * * * \\
(.020)\end{array}$ \\
\hline Foreign ownership $(\%)$ & $\begin{array}{l}-.135 * * * \\
(.010)\end{array}$ & $\begin{array}{l}.036 \\
(.050)\end{array}$ & $\begin{array}{l}-.020 \\
(.023)\end{array}$ & $\begin{array}{l}-.092 * * \\
(.046)\end{array}$ & $\begin{array}{l}-.043 * * * \\
(.015)\end{array}$ & $\begin{array}{l}.034 \\
(.109)\end{array}$ & $\begin{array}{l}-.185 * * * \\
(.019)\end{array}$ \\
\hline Manager experience $(\%)$ & $\begin{array}{l}.077 * * * \\
(.023)\end{array}$ & $\begin{array}{l}.142 * * * \\
(.036)\end{array}$ & $\begin{array}{l}.005 \\
(.050)\end{array}$ & $\begin{array}{l}-.068 \\
(.107)\end{array}$ & $\begin{array}{l}.041 \\
(.044)\end{array}$ & $\begin{array}{l}-.542 * * * \\
(.153)\end{array}$ & $\begin{array}{l}-.007 \\
(.063)\end{array}$ \\
\hline Financial audit & $\begin{array}{l}8.541 * * * \\
(.509)\end{array}$ & $\begin{array}{l}12.567 * * * \\
(.774)\end{array}$ & $\begin{array}{l}4.550 * * * \\
(1.149)\end{array}$ & $\begin{array}{l}5.586 * * * \\
(1.602)\end{array}$ & $\begin{array}{l}-.562 \\
(1.608)\end{array}$ & $\begin{array}{l}3.667 \\
(2.229)\end{array}$ & $\begin{array}{l}4.107 * * * \\
(1.304)\end{array}$ \\
\hline ISO certificate & $\begin{array}{l}3.041 * * * \\
(0.516)\end{array}$ & $\begin{array}{l}1.351 * \\
(.707)\end{array}$ & $\begin{array}{l}-1.235 \\
(1.300)\end{array}$ & $\begin{array}{l}3.706^{*} \\
(1.965)\end{array}$ & $\begin{array}{l}-1.454 \\
(1.194)\end{array}$ & $\begin{array}{l}5.893 * * \\
(2.555)\end{array}$ & $\begin{array}{l}10.230 * * * \\
(1.523)\end{array}$ \\
\hline Constant & $\begin{array}{l}40.800 * * * \\
(1.438)\end{array}$ & $\begin{array}{l}58.083 * * * \\
(1.275)\end{array}$ & $\begin{array}{l}-5.148 \\
(3.397)\end{array}$ & $\begin{array}{l}-5.587 * \\
(2.914)\end{array}$ & $\begin{array}{l}3.993 \\
(3.164)\end{array}$ & $\begin{array}{l}1.143 \\
(4.522)\end{array}$ & $\begin{array}{l}26.492 * * * \\
(3.569)\end{array}$ \\
\hline Observations & 19,879 & 10,241 & 2,581 & 1,014 & 2,241 & 764 & 3,038 \\
\hline R-squared & .139 & .107 & .054 & .063 & .044 & .146 & .127 \\
\hline $\begin{array}{l}\text { Time FE } \\
\text { Country FE }\end{array}$ & $\begin{array}{l}\text { YES } \\
\text { YES }\end{array}$ & YES & YES & YES & YES & YES & YES \\
\hline Industry FE & YES & YES & YES & YES & YES & YES & YES \\
\hline
\end{tabular}

SME = small and medium-sized enterprise.

Note: This table reports regression results of bank borrowing as a percentage of working capital (continuous dependent variable) on firm characteristics (control variables) for firms at different sizes. Robust standard errors are in parentheses; $* * *(* *, *)$ denotes statistical significance at the $1 \%(5 \%, 10 \%)$ level.

Source: Author's calculations using World Bank Enterprise Survey data.

\section{Lender Type}

Table 3.6 provides a Probit estimation of a dummy variable for lender type on borrowing firm characteristics. The lender type considered includes private commercial banks, state-owned banks, non-bank financial institutions and others. The results suggest that SMEs are less likely to borrow from private commercial banks, but are more likely to secure a loan from stateowned banks. Export oriented firms tend to borrow from private commercial banks and less likely to borrow from non-bank financial institutions. Foreign-owned firms are less likely to borrow from state-owned banks and tend to borrow from private commercial banks and other sources. Firms with financial audit and ISO certificate are less likely to borrow from non-bank financial institutions. 
Table 3. 6 Lender Type

\begin{tabular}{|c|c|c|c|c|}
\hline \multirow{2}{*}{$\begin{array}{l}Y=\text { Lender Type } \\
\text { Borrowed from }\end{array}$} & \multicolumn{4}{|c|}{ Probit Estimation: Probability of Lender Type } \\
\hline & $\begin{array}{l}\text { Private Commercial } \\
\text { Banks }\end{array}$ & $\begin{array}{l}\text { State owned } \\
\text { Banks }\end{array}$ & $\begin{array}{l}\text { Non-Bank } \\
\text { Institutions }\end{array}$ & Other \\
\hline \multirow[t]{2}{*}{ SME } & $-.1842 * * *$ & $.1459 * * *$ & .1818 & .1591 \\
\hline & $(.055)$ & $(.055)$ & $(.119)$ & $(.161)$ \\
\hline \multirow[t]{2}{*}{ Firm_age } & -.0006 & .0012 & .0012 & $-.0123 *$ \\
\hline & $(.002)$ & $(.002)$ & $(.003)$ & $(.006)$ \\
\hline \multirow[t]{2}{*}{$\operatorname{Exports}(\%)$} & $.0019 * *$ & -.0012 & $-.0067 * *$ & -.0003 \\
\hline & $(.001)$ & $(.001)$ & $(.003)$ & $(.002)$ \\
\hline \multirow[t]{2}{*}{ Foreign ownership $(\%)$} & $.0038 * * *$ & $-.0058 * * *$ & -.0014 & $.0073 * * *$ \\
\hline & $(.001)$ & $(.001)$ & $(.003)$ & $(.002)$ \\
\hline \multirow[t]{2}{*}{ Manager experience $(\%)$} & -.0010 & .0012 & -.0009 & .0017 \\
\hline & $(.002)$ & $(.002)$ & $(.004)$ & $(.008)$ \\
\hline \multirow[t]{2}{*}{ Financial audit } & .0358 & .0423 & $-.3599 * * *$ & -.1207 \\
\hline & $(.053)$ & $(.053)$ & $(.104)$ & $(.140)$ \\
\hline \multirow[t]{2}{*}{ ISO certificate } & .0413 & -.0077 & $-.1678 *$ & .0684 \\
\hline & $(.049)$ & $(.048)$ & $(.099)$ & $(.120)$ \\
\hline \multirow[t]{2}{*}{ Constant } & -.2418 & .0226 & $-1.8149 * * *$ & $-1.5018 * * *$ \\
\hline & $(.266)$ & $(.265)$ & $(.395)$ & $(.431)$ \\
\hline Observations & 5,592 & 5,598 & 5,451 & 4,340 \\
\hline Time FE & YES & YES & YES & YES \\
\hline Country FE & YES & YES & YES & YES \\
\hline Industry FE & YES & YES & YES & YES \\
\hline Log likelihood & -2675 & -2681 & -566.4 & -235 \\
\hline Pseudo R-squared & .295 & .304 & .110 & .110 \\
\hline
\end{tabular}

SME = small and medium-sized enterprise.

Note: This table reports regression results of lender type (dummy dependent variable) on firm characteristics (control variables) for firms at different sizes. The estimation method is Probit. The analysis pools firm observations across India, Malaysia, Thailand, Indonesia, the Philippines, and Viet Nam. Robust standard errors are in parentheses; $* * *(* *, *)$ denotes statistical significance at the $1 \%(5 \%, 10 \%)$ level.

Source: Author's calculations using World Bank Enterprise Survey data.

Table 3.7 provides results by firm size. Bank borrowing as a percentage of working capital is estimated on firm characteristics by size categories: $0-25,25-100,100-250$, and $250+$. The estimation results suggest that bank borrowing is positively associated with export participation and financial audit for all firm size categories, while firm age is negatively linked to bank borrowing for firms with 100 or fewer employees. This further emphasize our findings that small firms lack the ability to signal their quality to banks and may be partly attributable to the stigma that old and smaller firms are less productive or profitable. The effect of foreign ownership on bank borrowing is negative for all firms and but only statistically significant for firms with more than 25 employees. Financial audit and managerial experience have positive signal for all firm sizes. Having an ISO certification is positively associated with bank 
borrowing for firms with fewer than 25 employees and for firms with more than 250 employees.

Table 3. 7 Firm Size and Bank Borrowing (\% working capital)

\begin{tabular}{|c|c|c|c|c|}
\hline \multirow{2}{*}{$\begin{array}{l}\mathrm{Y}=\text { Bank Borrowing } \\
(\% \text { working capital })\end{array}$} & \multicolumn{4}{|c|}{ Firm Size (number of employees) } \\
\hline & $<=25$ & $>25$ and $<=100$ & $>100$ and $<=250$ & $>250$ \\
\hline \multirow[t]{2}{*}{ Firm_age } & $-.0452 *$ & $-.0818 * *$ & .0050 & .0094 \\
\hline & $(.027)$ & $(.034)$ & $(.044)$ & $(.046)$ \\
\hline \multirow[t]{2}{*}{ Exports $(\%)$} & $.0395 * *$ & $.0889 * * *$ & $.0480 * *$ & $.0470 * *$ \\
\hline & $(.018)$ & $(.016)$ & $(.019)$ & $(.020)$ \\
\hline \multirow[t]{2}{*}{ Foreign ownership(\%) } & -.0124 & $-.1374 * * *$ & $-.1429 * * *$ & $-.1574 * * *$ \\
\hline & $(.025)$ & $(.017)$ & $(.023)$ & $(.021)$ \\
\hline \multirow[t]{2}{*}{ Manager experience $(\%)$} & .0274 & $.1429 * * *$ & .0826 & .0899 \\
\hline & $(.033)$ & $(.042)$ & $(.066)$ & $(.072)$ \\
\hline \multirow[t]{2}{*}{ Financial audit } & $8.8057 * * *$ & $9.7502 * * *$ & $5.3351 * * *$ & $4.8836^{* * *}$ \\
\hline & $(.722)$ & $(.973)$ & $(1.513)$ & $(1.672)$ \\
\hline \multirow[t]{2}{*}{ ISO certificate } & $2.6483 * * *$ & 1.0317 & -1.0759 & $4.8447 * * *$ \\
\hline & $(.945)$ & $(.864)$ & $(1.243)$ & $(1.447)$ \\
\hline \multirow[t]{2}{*}{ Constant } & $-7.5675 * * *$ & $12.2504 * * *$ & $20.4596 * * *$ & $-17.8717 * *$ \\
\hline & $(2.386)$ & $(2.560)$ & $(4.442)$ & $(8.590)$ \\
\hline Observations & 8,986 & 6,202 & 2,664 & 2,084 \\
\hline R-squared & .112 & .134 & .161 & .207 \\
\hline Time FE & YES & YES & YES & YES \\
\hline Country FE & YES & YES & YES & YES \\
\hline Industry FE & YES & YES & YES & YES \\
\hline
\end{tabular}

Note: This table reports regression results of bank borrowing as a percentage of working capital (continuous dependent variable) on firm characteristics (control variables) for firms at different sizes. The analysis pools firm observations across India, Malaysia, Thailand, Indonesia, the Philippines, and Viet Nam. Robust standard errors are in parentheses; $* * *(* *, *)$ denotes statistical significance at the $1 \%(5 \%, 10 \%)$ level.

Source: Author's calculations using World Bank Enterprise Survey data.

\section{Collateral Type}

Table 3.8.1 provides a Probit estimation of collateral type on firm characteristics. ${ }^{15}$ Results suggest that SMEs are more likely than larger firms to use personal assets as collateral and less likely to use other types of collateral. Firms with foreign ownership tend to use equipment as collateral rather than property while this finding is the opposite for firms with more experienced managers. Older firms, export-oriented firms, firms with ISO certificate and financiallyaudited firms tend to use less personal assets as collateral and more likely to use other types of

\footnotetext{
${ }^{15}$ Collateral type is the collateral for loan (property, equipment, account receivables, personal assets) that was required for most recent line of credit or loan. Thus, it is not necessarily a collateral type that is used to secure any loan in that year, it is simply a collateral that is present in that year.
} 
collateral. However, if we look at the percentage of firms reporting use of collateral, by type of collateral and firm size (number of employees), reported in Table 3.8.2, property and equipment do matter for SMEs as collateral. Our results show that, all else equal, property and equipment and account receivables are less important for SMEs relative to larger firms.

Table 3.8. 1 Collateral Type-All Firms

\begin{tabular}{|c|c|c|c|c|}
\hline$Y=$ Collateral in Use & $\begin{array}{l}(1) \\
\text { Property }\end{array}$ & $\begin{array}{l}\text { (2) } \\
\text { Equipment }\end{array}$ & $\begin{array}{l}(3) \\
\text { Account receivables }\end{array}$ & $\begin{array}{l}(4) \\
\text { Personal Assets }\end{array}$ \\
\hline SME & $\begin{array}{l}-.1517 * * * \\
(.049)\end{array}$ & $\begin{array}{l}-.2247 * * * \\
(.051)\end{array}$ & $\begin{array}{l}-.1286^{* *} \\
(.050)\end{array}$ & $\begin{array}{l}.2425^{* * * *} \\
(.052)\end{array}$ \\
\hline Firm_age & $\begin{array}{l}.0011 \\
(.002)\end{array}$ & $\begin{array}{l}.0041 * * \\
(.002)\end{array}$ & $\begin{array}{l}.0042 * * * \\
(.002)\end{array}$ & $\begin{array}{l}-.0106 * * * \\
(.002)\end{array}$ \\
\hline Exports $(\%)$ & $\begin{array}{l}.0028 * * * \\
(.001)\end{array}$ & $\begin{array}{l}.0019 * * \\
(.001)\end{array}$ & $\begin{array}{l}.0042 * * * \\
(.001)\end{array}$ & $\begin{array}{l}-.0015^{*} \\
(.001)\end{array}$ \\
\hline Foreign ownership $(\%)$ & $\begin{array}{l}-.0022 * * \\
(.001)\end{array}$ & $\begin{array}{l}.0049 * * * \\
(.001)\end{array}$ & $\begin{array}{l}.0017 \\
(.001)\end{array}$ & $\begin{array}{l}-.0065 * * * \\
(.001)\end{array}$ \\
\hline Manager experience $(\%)$ & $\begin{array}{l}.0076^{* * * *} \\
(.002)\end{array}$ & $\begin{array}{l}-.0043^{* *} \\
(.002)\end{array}$ & $\begin{array}{l}-.0020 \\
(.002)\end{array}$ & $\begin{array}{l}-.0054 * * \\
(.002)\end{array}$ \\
\hline Financial audit & $\begin{array}{l}.0076 \\
(.049)\end{array}$ & $\begin{array}{l}.3164 * * * \\
(.049)\end{array}$ & $\begin{array}{l}.2010 * * * \\
(.054)\end{array}$ & $\begin{array}{l}-.1442 * * * \\
(.050)\end{array}$ \\
\hline ISO certificate & $\begin{array}{l}.0683 \\
(.043)\end{array}$ & $\begin{array}{l}.2293 * * * \\
(.043)\end{array}$ & $\begin{array}{l}.1662 * * * \\
(.044)\end{array}$ & $\begin{array}{l}-.1058 * * \\
(.044)\end{array}$ \\
\hline Constant & $\begin{array}{l}.5176 \\
(.365)\end{array}$ & $\begin{array}{l}.2302 \\
(.399)\end{array}$ & $\begin{array}{l}-.7316 \\
(.470)\end{array}$ & $\begin{array}{l}-.4413 \\
(.527)\end{array}$ \\
\hline Observations & 5,756 & 5,736 & 5,689 & 5,673 \\
\hline Time FE & YES & YES & YES & YES \\
\hline Country FE & YES & YES & YES & YES \\
\hline Industry FE & YES & YES & YES & YES \\
\hline Log likelihood & -3331 & -3285 & -2992 & -3289 \\
\hline Pseudo R-squared & .0383 & .151 & .171 & .0804 \\
\hline
\end{tabular}

Note: This table reports regression results of collateral type (dummy dependent variable) on firm characteristics (control variables) for firms at different sizes. The estimation method is Probit. The analysis pools firm observations across India, Malaysia, Thailand, Indonesia, the Philippines, and Viet Nam. Standard errors are in parentheses; $* * *(* *, *)$ denotes statistical significance at the $1 \%(5 \%, 10 \%)$ level.

Source: Author's calculations using World Bank Enterprise Survey data.

Table 3.8. 2 Collateral Use across Firm Size

\begin{tabular}{|l|l|l|l|}
\hline $\begin{array}{l}\text { Firm Size } \\
\text { (number of employees) }\end{array}$ & Properties and Equipment & Account Receivables & Personal Assets \\
\hline$\leq 25$ & $81.07 \%$ & $28.52 \%$ & $39.94 \%$ \\
\hline$>25$ and $\leq 100$ & $88.43 \%$ & $38.65 \%$ & $35.35 \%$ \\
\hline$>100$ and $\leq 250$ & $90.67 \%$ & $38.54 \%$ & $29.89 \%$ \\
\hline$>250$ & $89.78 \%$ & $43.26 \%$ & $26.82 \%$ \\
\hline
\end{tabular}

Note: This table provides the percentages of firms reporting use of collateral, by type of collateral and firm size (number of employees).

Source: Author's calculations using World Bank Enterprise Survey data. 


\subsubsection{Economic Significance}

We summarize our findings in Figures 3.3.1 and 3.3.2, highlighting economic significance of the main results. To calculate economic significance of explanatory variables on line of credit availability (and bank borrowing), we multiply a coefficient estimate of variable with a standard deviation of variable; dubbed economic significance of a one-standard deviation increase of variable. For instance, a coefficient estimate of SME dummy variable in the estimation of Table 3.4 first column is -0.23 , a standard deviation of SME dummy variable is 0.39 , hence the economic significance of a one-standard deviation increase of SME dummy variable lowers bank borrowing as percentage of working capital by -9 percent. ${ }^{16} \mathrm{We}$ drop from calculation the variables that are statistically insignificant.

Figure 3.3. 1 Economic Significance of a One-Standard-Deviation Increase of Firm Characteristics on Line of Credit Availability (\% probability)

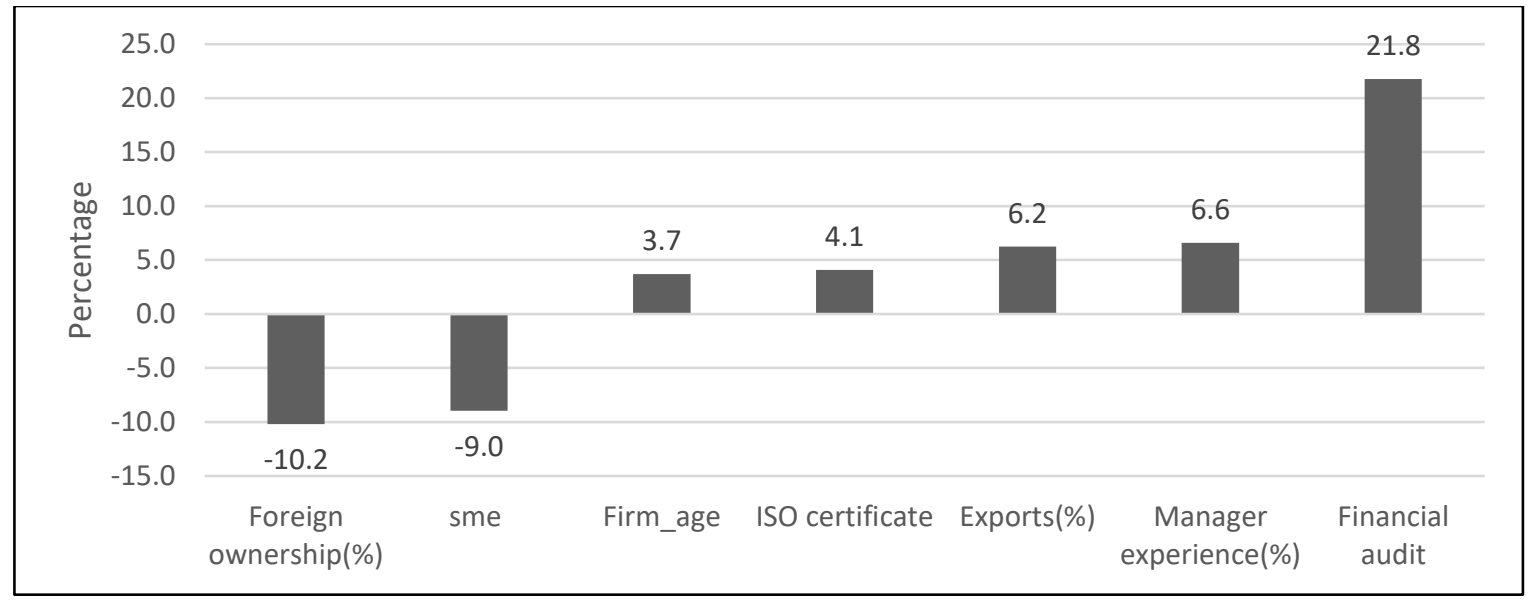

SME $=$ small and medium-sized enterprise.

Source: Authors' calculations.

Figure 3.3.1 provides the economic significance of the explanatory variables on line of credit availability. For variables with negative association with line of credit availability, foreign ownership has the largest economic significance $(-10.2 \%)$, followed by SME indicator $(-9 \%)$. For variables with positive association with line of credit availability, financial audit has the

\footnotetext{
${ }^{16}$ Summary statistics for firm-level variables from estimation samples are available upon request.
} 
largest economic significance (21.8\%), followed by manager experience $(6.6 \%)$, and export participation $(6.2 \%)$.

Figure 3.3. 2 Economic Significance of a One-Standard-Deviation Increase of Firm Characteristics on Proportion of Bank Borrowing (\% of working capital)

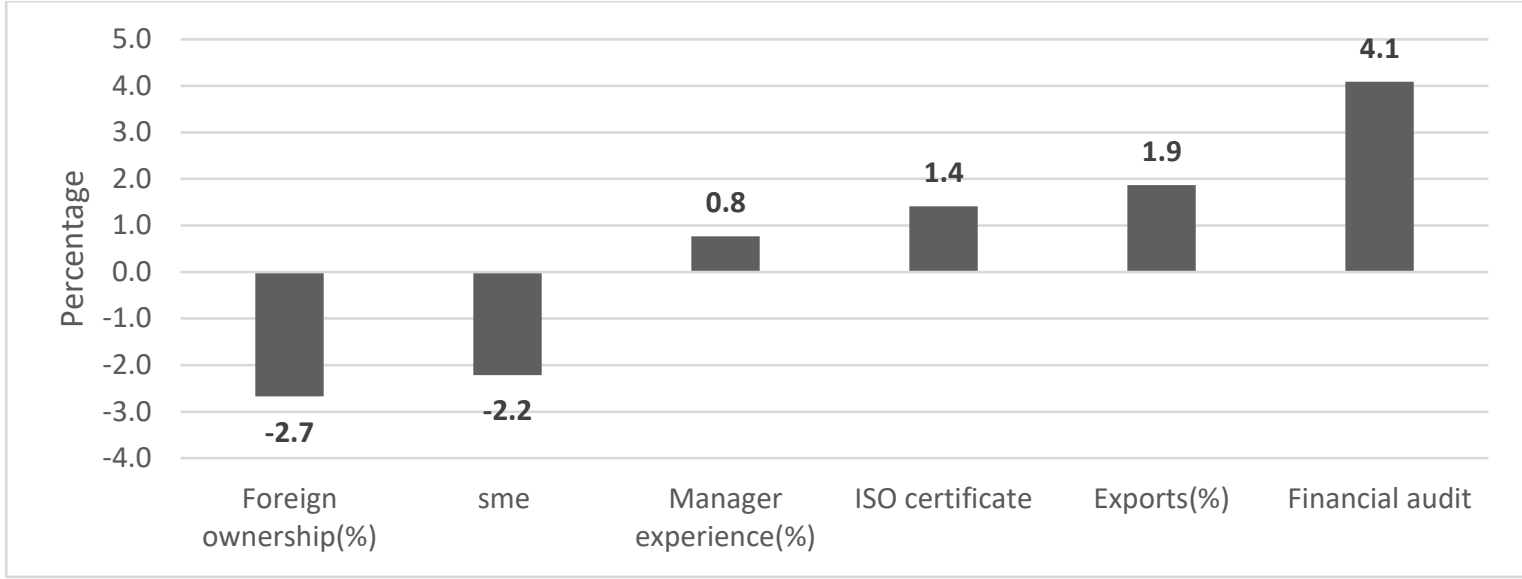

SME $=$ small and medium-sized enterprise.

Source: Authors' calculations.

Figure 3.3.2 provides the economic significance of the explanatory variables on bank borrowing as a percentage of working capital. A calculation is done likewise; a coefficient estimate from the Table 3.4 column 2 is multiplied by the variable's standard deviation. For variables with negative association with bank borrowing, foreign ownership has the largest economic significance $(-2.7 \%)$, followed by SME status $(-2.2 \%)$. For variables with positive association with bank borrowing, financial audit has the largest economic significance $(4.1 \%)$, followed by export participation (1.9\%) and ISO certificate (1.4\%).

The economic significance supports our findings that SME status has a large, negative relationship with bank borrowing and line of credit availability. Having financial audits also helps firms in accessing finance, as the audit improves financial education and transparency, which increase the credibility of firms in view of potential creditors. In addition, export participation, ISO certification and managerial experience are consistently driving both bank borrowing and line of credit availability. The ability to enter foreign markets also serves as a signal of competitiveness and high productivity, enabling access to bank borrowing and line of credit availability. Export participation is also associated with the need to grow larger in scale, and hence a greater demand for external finance from bank borrowing and line of credit availability. 
On the other hand, we find that foreign ownership is negatively associated with line of credit availability and bank borrowing. This finding is plausible as firms with foreign ownership may have less necessity for bank borrowing in domestic markets since a firm's working capital can be supported by trade credit in supply chains and borrowing in international capital markets through a parent company.

\subsection{Policy Implications and Conclusions}

Using World Bank Enterprise Survey data, this study examines the relationship between firm characteristics and SME finance in a sample of firms from India, Indonesia, Malaysia, the Philippines, Thailand, and Viet Nam. Several aspects of financial access, including bank borrowing, line of credit availability, and collateral, credit, and lender type are found to be correlated with firm characteristics. The main results suggest that SME status has a significant large and negative economic influence on bank borrowing and line of credit availability, while export participation, ISO certification, and financial audit have opposite and significantly positive effects on SME external financing.

While the focus is on firms in India and Southeast Asia, our main findings suggest both similarities and differences to previous studies on other economies and sample periods. In Germany, the evidence suggests that SMEs, known as "Mittelstand," become less reliant on bank borrowing and more on equity finance and future cash flows, while capital market instruments (i.e., Mittelstand bonds) remain available to only large firms (Böttcher, 2013). SMEs in our sample countries remain dependent on internal funds and the use of bank financing for investments is still at low levels (see appendix Figure 3.A.2) although there was remarkable improvement in few of these countries (i.e., Indonesia, Malaysia).

Results can be driven by several factors such as shortage of acceptable collateral and equity. Additionally, lending to SMEs also involves higher credit administration costs and greater risks (Pansiri \& Temtime, 2010).

Thus, financial access of SMEs in developing Asia is more challenging, given the lower level of capital market development, SME financing institutions and perhaps a greater problem of asymmetric information between SME lenders and borrowers.

In the United Kingdom, it is found that SMEs also have difficulty in borrowing from banks especially after the global financial crisis of 2008-2009, thereby influencing the UK 
government to intervene with long-term guarantee and credit schemes for new loans, as well as to support commercially managed venture capital funds for providing equity finance (BIS, 2012). The framework and implementation of government policies regarding collaterals and credit guarantees can be important to SME finance in developing Asia. In advanced economies, evidence from Japan has shown that banks tend to monitor small business borrowers more closely when lending is collateralized (Ono \& Uesugi, 2009), and cross-country evidence suggest that governments can indeed support funding of small firms and new enterprises productively through credit guarantee schemes (Beck, Klapper, \& Mendoza, 2010) (Beck et al., 2010). As for the role of venture capital funding for SME finance in developing Asia, it is relatively non-existent at present, and more exploration is required on its implementation and effectiveness. Japan has developed hometown investment trust funds (Yoshino, 2013) (Yoshino, 2013), which could potentially be applicable to SME finance in developing Asian economies.

Finally, results obtained in this study are based on reduced-form analysis without considering the role of underlying models of how firms make decisions and expectations of firms in regard to change in future policy reforms. Therefore, the use of these results in policy design should be considered carefully due to the possibility of Lucas critique effects.

There are several useful directions for further research on SME finance in developing Asia. First, the current research on India and Southeast Asia can be strengthened by using a panel data set and a larger sample of firms when this becomes available in the future. Furthermore, it would be valuable to expand the sample of countries to cover other South Asian economies. Second, the current dataset was largely a self-assessment by firms and thus did not cover the credit worthiness of SMEs from the viewpoint of lenders. The collection of credit scoring information at the firm level and development of a credit risk database would be informative. Third, the dataset did not permit exploration of the role of inter-country regulatory and institutional factors on SME finance. The preparation of case studies may be a tool for such analysis. 


\section{Appendix: Robustness Check}

\section{Country-Specific Results}

Tables 3.A.1 provides country-specific results, along with results using a pooled countries sample for line of credit availability. Results suggest that SME status have consistent negative impact on line of credit availability. Firm age and financial audit are positively associated with line of credit availability in each of the countries in our sample. Except Philippines and Malaysia, export participation is positively related to line of credit availability in all countries, while foreign ownership has a positive association with line of credit availability only in India and Thailand. Managerial experience and ISO certification are positively linked to line of credit availability in all countries, except Thailand and Indonesia, respectively.

Table 3.A. 1 Country-Specific Results. Line of Credit Availability

\begin{tabular}{|c|c|c|c|c|c|c|c|}
\hline $\begin{array}{l}\mathrm{Y}=\text { Line of Credit } \\
\text { Availability }\end{array}$ & All & India & Indonesia & Malaysia & Philippines & Thailand & Viet Nam \\
\hline$\overline{\mathrm{SME}}$ & $\begin{array}{l}-.232 * * * \\
(.027)\end{array}$ & $\begin{array}{l}-.164 * * * \\
(.035)\end{array}$ & $\begin{array}{l}-.394 * * * \\
(.080)\end{array}$ & $\begin{array}{l}-.182 \\
(.152)\end{array}$ & $\begin{array}{l}-.427 * * * \\
(.100)\end{array}$ & $\begin{array}{l}.037 \\
(.236)\end{array}$ & $\begin{array}{l}-.424 * * * \\
(.082)\end{array}$ \\
\hline Firm_age & $\begin{array}{l}.003 * * * \\
(.001)\end{array}$ & $\begin{array}{l}.002 \\
(.001)\end{array}$ & $\begin{array}{l}.007 * * \\
(.003)\end{array}$ & $\begin{array}{l}.003 \\
(.006)\end{array}$ & $\begin{array}{l}.005^{*} \\
(.002)\end{array}$ & $\begin{array}{l}.003 \\
(.008)\end{array}$ & $\begin{array}{l}.001 \\
(.002)\end{array}$ \\
\hline Exports $(\%)$ & $\begin{array}{l}.002 * * * \\
(.000)\end{array}$ & $\begin{array}{l}.004 * * * \\
(.001)\end{array}$ & $\begin{array}{l}.003 * \\
(.001)\end{array}$ & $\begin{array}{l}-.000 \\
(.002)\end{array}$ & $\begin{array}{l}-.002 * \\
(.001)\end{array}$ & $\begin{array}{l}.007 * * \\
(.003)\end{array}$ & $\begin{array}{l}.001 * \\
(.001)\end{array}$ \\
\hline Foreign ownership $(\%)$ & $\begin{array}{l}-.005 * * * \\
(.001)\end{array}$ & $\begin{array}{l}.004^{*} \\
(.002)\end{array}$ & $\begin{array}{l}-.000 \\
(.001)\end{array}$ & $\begin{array}{l}-.004 \\
(.003)\end{array}$ & $\begin{array}{l}-.005 * * * \\
(.001)\end{array}$ & $\begin{array}{l}.009 * \\
(.005)\end{array}$ & $\begin{array}{l}-.008 * * * \\
(.001)\end{array}$ \\
\hline Manager experience $(\%)$ & $\begin{array}{l}.007 * * * \\
(.001)\end{array}$ & $\begin{array}{l}.012 * * * \\
(.002)\end{array}$ & $\begin{array}{l}.003 \\
(.003)\end{array}$ & $\begin{array}{l}.002 \\
(.006)\end{array}$ & $\begin{array}{l}.004 \\
(.003)\end{array}$ & $\begin{array}{l}-.016 * \\
(.009)\end{array}$ & $\begin{array}{l}.001 \\
(.003)\end{array}$ \\
\hline Financial audit & $\begin{array}{l}.454 * * * \\
(.026)\end{array}$ & $\begin{array}{l}.645^{* * *} \\
(.042)\end{array}$ & $\begin{array}{l}.320 * * * \\
(.081)\end{array}$ & $\begin{array}{l}.197 * * \\
(.093)\end{array}$ & $\begin{array}{l}.297 * * * \\
(.096)\end{array}$ & $\begin{array}{l}.835 * * * \\
(.138)\end{array}$ & $\begin{array}{l}.208 * * * \\
(.058)\end{array}$ \\
\hline ISO certificate & $\begin{array}{l}.088 * * * \\
(.023)\end{array}$ & $\begin{array}{l}.006 \\
(.030)\end{array}$ & $\begin{array}{l}-.192 * * \\
(.094)\end{array}$ & $\begin{array}{l}.267 * * \\
(.114)\end{array}$ & $\begin{array}{l}.250 * * * \\
(.079)\end{array}$ & $\begin{array}{l}.586 * * * \\
(.174)\end{array}$ & $\begin{array}{l}.332 * * * \\
(.065)\end{array}$ \\
\hline Constant & $\begin{array}{l}.086 \\
(.227)\end{array}$ & $\begin{array}{l}-2.144 * * * \\
(.136)\end{array}$ & $\begin{array}{l}.548 \\
(.504)\end{array}$ & $\begin{array}{l}-.526 \\
(.704)\end{array}$ & $\begin{array}{l}-.828 * * \\
(.325)\end{array}$ & $\begin{array}{l}-.208 \\
(.764)\end{array}$ & $\begin{array}{l}.407 \\
(.254)\end{array}$ \\
\hline Observations & 19,808 & 10,629 & 2,550 & 815 & 2,019 & 698 & 3,038 \\
\hline $\begin{array}{l}\text { Time FE } \\
\text { Country FE }\end{array}$ & $\begin{array}{l}\text { YES } \\
\text { YES }\end{array}$ & YES & YES & YES & YES & YES & YES \\
\hline Industry FE & YES & YES & YES & YES & YES & YES & YES \\
\hline Log likelihood & -11838 & -6110 & -1480 & -527.7 & -1251 & -265.2 & -1925 \\
\hline Pseudo R-squared & .0818 & .0904 & .0517 & .0433 & .0728 & .184 & .0853 \\
\hline
\end{tabular}

SME = small and medium-sized enterprise.

Note: This table reports regression results of line of credit availability (dummy dependent variable) on firm characteristics (control variables) for firms at different sizes. The estimation method is Probit. Robust standard errors are in parentheses; *** (**, *) denotes statistical significance at the $1 \%(5 \%, 10 \%)$ level.

Source: Author's calculations using World Bank Enterprise Survey data 
Table 3.A.2 provides the estimates of firm characteristics on portion of investments (i.e. fixed assets such as buildings and land) that are financed from bank borrowing. We present results using a pooled countries sample along with country-specific results. Findings suggest that SME status has a negative sign on bank borrowing in all countries, except in Indonesia and Thailand. Firm age is negatively associated with bank borrowing in Malaysia and Philippines, while it has a positive impact in Viet Nam sub-sample. Export participation is positively linked to bank borrowing in Thailand while it has an opposite relationship in Malaysia sub-sample. The effect of foreign ownership on bank borrowing is negative and statistically significant in all countries, but India and Thailand. Managerial experience is positively related to bank borrowing in India while it has a negative association in Viet Nam sub-sample. Financial audit has a positive impact on bank borrowing in pooled sample as well as in Indonesia and Viet Nam sub-samples, while having an ISO certification is negatively related to bank borrowing in Malaysia and Philippines.

Table 3.A. 2 Bank borrowing (\% new investments)

\begin{tabular}{|c|c|c|c|c|c|c|c|}
\hline $\begin{array}{l}Y=\text { Bank Borrowing } \\
\text { (\% new investments) }\end{array}$ & All & India & Indonesia & Malaysia & Philippines & Thailand & Viet Nam \\
\hline SME & $\begin{array}{l}-5.801 * * * \\
(1.104)\end{array}$ & $\begin{array}{l}-6.267 * * * \\
(1.533)\end{array}$ & $\begin{array}{l}5.160 * * \\
(2.617)\end{array}$ & $\begin{array}{l}-1.726 \\
(4.339)\end{array}$ & $\begin{array}{l}-12.454 * * * \\
(3.415)\end{array}$ & $\begin{array}{l}17.598 \\
(12.107)\end{array}$ & $\begin{array}{l}-3.597 \\
(2.494)\end{array}$ \\
\hline Firm_age & $\begin{array}{l}.058^{*} \\
(.034)\end{array}$ & $\begin{array}{l}.005 \\
(.049)\end{array}$ & $\begin{array}{l}.018 \\
(.086)\end{array}$ & $\begin{array}{l}-.273 * * \\
(.122)\end{array}$ & $\begin{array}{l}-.132 * \\
(.069)\end{array}$ & $\begin{array}{l}.314 \\
(.536)\end{array}$ & $\begin{array}{l}.312 * * * \\
(.082)\end{array}$ \\
\hline Exports $(\%)$ & $\begin{array}{l}.024 \\
(.016)\end{array}$ & $\begin{array}{l}.024 \\
(.027)\end{array}$ & $\begin{array}{l}.066 \\
(.045)\end{array}$ & $\begin{array}{l}-.075^{*} \\
(.045)\end{array}$ & $\begin{array}{l}.018 \\
(.039)\end{array}$ & $\begin{array}{l}.320 * \\
(.172)\end{array}$ & $\begin{array}{l}.037 \\
(.028)\end{array}$ \\
\hline $\begin{array}{l}\text { Foreign } \\
\text { ownership }(\%)\end{array}$ & $\begin{array}{l}-.094 * * * \\
(.017)\end{array}$ & $\begin{array}{l}.114 \\
(.098)\end{array}$ & $\begin{array}{l}-.121 * * * \\
(.032)\end{array}$ & $\begin{array}{l}-.103 * * * \\
(.033)\end{array}$ & $\begin{array}{l}-.070 * * \\
(.031)\end{array}$ & $\begin{array}{l}.236 \\
(.314)\end{array}$ & $\begin{array}{l}-.113 * * * \\
(.030)\end{array}$ \\
\hline Manager experience(\%) & $\begin{array}{l}.070 \\
(.044)\end{array}$ & $\begin{array}{l}.198 * * * \\
(.069)\end{array}$ & $\begin{array}{l}.004 \\
(.113)\end{array}$ & $\begin{array}{l}.236 \\
(.170)\end{array}$ & $\begin{array}{l}.048 \\
(.097)\end{array}$ & $\begin{array}{l}-.323 \\
(.415)\end{array}$ & $\begin{array}{l}-.186 * * \\
(.089)\end{array}$ \\
\hline Financial audit & $\begin{array}{l}3.981 * * * \\
(1.116)\end{array}$ & $\begin{array}{l}2.937 \\
(2.163)\end{array}$ & $\begin{array}{l}8.740 * * * \\
(3.244)\end{array}$ & $\begin{array}{l}5.057 \\
(3.232)\end{array}$ & $\begin{array}{l}3.076 \\
(4.442)\end{array}$ & $\begin{array}{l}-2.899 \\
(9.479)\end{array}$ & $\begin{array}{l}3.675^{*} \\
(1.933)\end{array}$ \\
\hline ISO certificate & $\begin{array}{l}-.806 \\
(.950)\end{array}$ & $\begin{array}{l}-.401 \\
(1.384)\end{array}$ & $\begin{array}{l}3.091 \\
(3.404)\end{array}$ & $\begin{array}{l}-6.307 * * \\
(2.504)\end{array}$ & $\begin{array}{l}-8.540 * * * \\
(2.536)\end{array}$ & $\begin{array}{l}-14.368 \\
(9.466)\end{array}$ & $\begin{array}{l}1.858 \\
(2.020)\end{array}$ \\
\hline Constant & $\begin{array}{l}7.619 * \\
(4.458)\end{array}$ & $\begin{array}{l}55.229 * * * \\
(1.651)\end{array}$ & $\begin{array}{l}-1.268 \\
(4.727)\end{array}$ & $\begin{array}{l}68.845 * * * \\
(4.701)\end{array}$ & $\begin{array}{l}14.327^{*} \\
(7.776)\end{array}$ & $\begin{array}{l}-6.982 \\
(24.734)\end{array}$ & $\begin{array}{l}-.782 \\
(4.391)\end{array}$ \\
\hline Observations & 7,419 & 3,648 & 459 & 336 & 854 & 86 & 2,036 \\
\hline R-squared & .072 & .051 & .106 & .222 & .076 & .288 & .071 \\
\hline Time FE & YES & YES & YES & YES & YES & YES & YES \\
\hline $\begin{array}{l}\text { Country FE } \\
\text { Industry FE }\end{array}$ & $\begin{array}{l}\text { YES } \\
\text { YES }\end{array}$ & YES & YES & YES & YES & YES & YES \\
\hline
\end{tabular}

Note: This table reports regression results of bank borrowing as a percentage of new investments, i.e. fixed assets (continuous dependent variable) on firm characteristics (control variables) for firms at different sizes. Robust standard errors are in parentheses; *** $(* *, *)$ denotes statistical significance at the $1 \%(5 \%, 10 \%)$ level. Source: Author's calculations using World Bank Enterprise Survey data. 
Figure 3.A.1 provides the economic significance of the explanatory variables on proportion of new investments that are financed by bank borrowing from Table 3.A.2 column 1. SME status has the largest magnitude with one-standard deviation increase of SME dummy variable associated with -2.5 percent decrease in bank borrowing as percentage of new investments. Financial audit has the largest positive impact (1.8\%), followed by firm age $(0.8 \%)$.

Figure 3.A. 1 Economic Significance of a One-Standard-Deviation Increase of Firm Characteristics on Proportion of Bank Borrowing (\% of new investments)

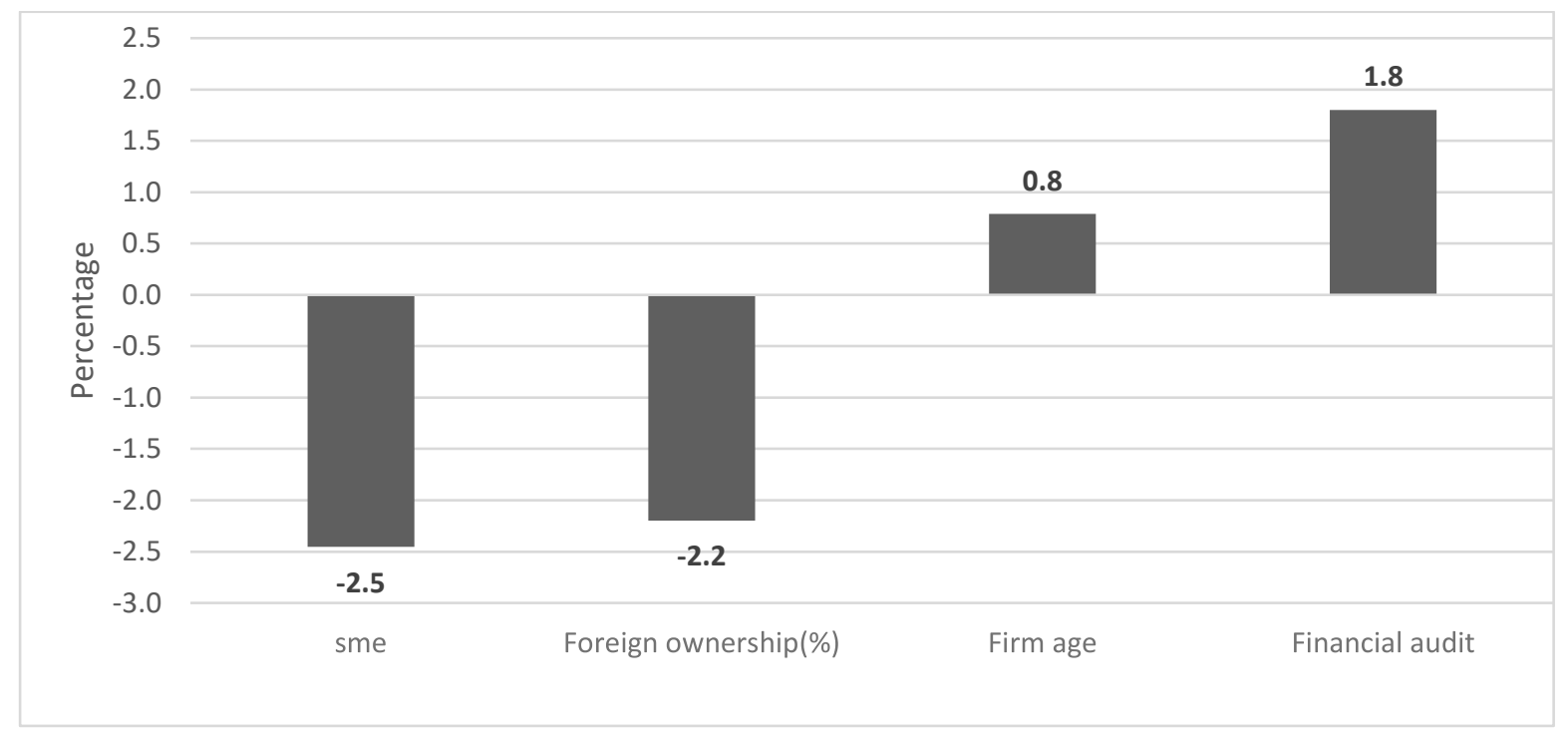

$\mathrm{SME}=$ small and medium-sized enterprise.

Source: Authors' calculations.

Figure 3.A. 2 Percent of firms using banks to finance investments

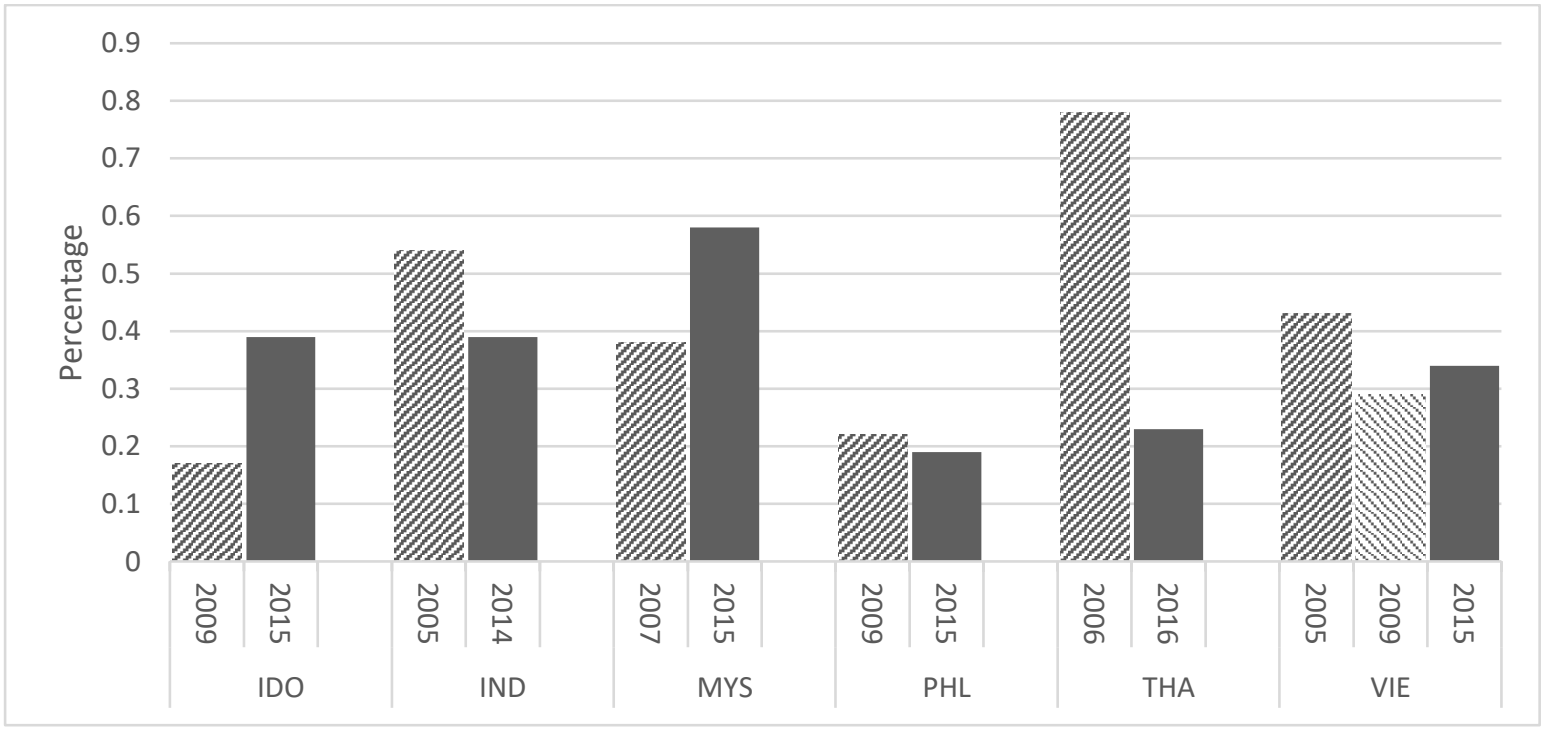

Source: Author's calculations using World Bank Enterprise Survey data 


\title{
Chapter 4
}

\section{Role of Infrastructure Investment Deals as a Signalling on FDI. Case of Developing Countries.}

\begin{abstract}
This chapter studies the role of infrastructure investment deals on attracting foreign direct investment (FDI) in developing countries. We argue that announcement of infrastructure deals contain valuable source of information for multinational firms and therefore should contribute to their decision making process regarding the host country. Our results indicate that infrastructure investment deals indeed play an important role for the decision making of foreign investors, however, the effect is not always positive as one could expect. Intriguingly, the estimation results show that signaling is negative for the full sample of developing countries. We test for several channels in which the negative signalling can pass through. Findings show that the signaling effect mainly depends on distressed situations that emerges from host country's specific risk level. Particularly, in heavily indebted countries, increase in number of infrastructure projects may associate with a high possibility of government default and economic instability in the near future and thus adversely affect FDI. Our research is the first attempt to study this topic and contributes to literature on the relationship signalling and FDI.
\end{abstract}




\subsection{Introduction}

Attracting foreign direct investment (FDI) has always been one of the main policy agendas of developing countries. It's well known in literature that FDI brings additional source of capital, knowledge transfer, employment and thereby economic progress to developing countries given that right circumstances are satisfied. There are extensive literature about factors that attract FDI, i.e., the size and development of host country markets, human capital, institutional quality and overall infrastructure endowment, and other motives such as natural resources endowment and geographical and cultural proximity to major source countries. However, these are factors that are mostly beyond the realm of short-term policy making and in many cases investors look for additional source of information that may contribute to their decision making process. One of the factors that haven't been addressed in literature is the signalling effect. In this paper, we look at signalling channel by exploring how private infrastructure investment deals attract FDI.

Infrastructures are highly capital intensive long term projects involving intense host country government engagement and high degree of regulatory risk. Investors deciding whether to invest or not in such complex projects need to take into account all possible political, economic and regulatory risks that may affect the viability of a project both in the short and long term. This makes infrastructure investors highly risk averse to any kind of uncertainty and countries with potential risks are less likely to receive these type of investments. Therefore, considering the amount of risks the infrastructure projects face, they contain valuable source of information for multinational firms in their decision making process regarding the host country. It provides not only a source of information for foreign investors in terms of its potential impact on host country economic activity (i.e., increase in economic activity and productivity through increase in quality of infrastructure), but also signals a better environment for FDI regarding the 
credibility of host government and overall quality of the business environment. Thus, by observing past infrastructure deals, it is eventually possible for multinational firms to infer the critical information regarding the country fundamentals incorporated within the deal. Bearing all this in mind, we presume that past infrastructure deals should be perceived as a positive signal by foreign investors by reducing their risk aversion and information asymmetries towards investing country.

Yet on the other side, because of their complex characteristics and involvement of large scale capital, infrastructure projects may also make countries highly vulnerable to debt distress. This is due to the fact than when such large amounts of capital invested for a long duration of time, higher amount of risk is embedded within these projects, specifically in countries with limited resources and higher fiscal burden. This creates additional uncertainty regarding the credit stability of host country's economy and creates challenges for its sovereign debt sustainability (Hurley, Morris, \& Portelance, 2018). In other words, the riskiness of infrastructure projects may introduce new debt vulnerabilities in developing countries, increasing country-risk premium and uncertainty regarding the debt sustainability of the host country, risking growth prospective and thereby causing loss of trust in FDI investors.

Taking into account arguments mentioned above, this study investigates how private infrastructure deals affects FDI decision of multinational firms in developing countries. Do they produce a positive signal by creating a stimulus that host country business environment are safe to invest? Or do they introduce new debt vulnerabilities in developing countries increasing country risk and thereby reducing FDI?

Our results are intriguing and worth to examine. We find that infrastructure deals produces a negative signal to MNEs' decision making for developing countries. Several channels have been considered to understand the rationale behind the negative signalling effect can pass 
through. Findings suggest that increase in global risk aversion stemming from global financial crisis and country specific risk level are the main factors behind the negative signalling effect.

The rest of the chapter is structured as follows: Section 4.2 reviews empirical literature on the relationship between infrastructure and FDI. Section 4.3 describes data and methodology used in this study. Section 4.4 describes the results and Section 4.5 concludes.

\subsection{Literature Review on Infrastructure Endowment and FDI}

Due to data limitations there are no previous empirical studies examining effect of private investment in infrastructure on FDI and vice versa. However, considerable amount of studies examined the relationship between physical infrastructure endowment and FDI and also trade. Recent literature focusing on FDI supports the view that higher endowment of infrastructure can foster trade and investment. Sekkat and Varoudakis (2007) studied a panel of 20 to 72 developing countries and find that infrastructure has a significant attractiveness of FDI even than that of openness and investment climate in developing countries. Mollick et al., (2006) examined "international infrastructure" measured by telephone lines, and government expenditures on infrastructure as a determinants of FDI flows into Mexican states over 19942001. In their study, concentration of telephone lines appear to be statistically and economically important for FDI as their coefficients range from 1.98 to 2.02 in panel Random Effects Models (REM) estimations. They further argue that governments should encourage more support to international infrastructure as this type of investment appears to be more favourable to FDI than domestic infrastructure, such as interstate and secondary roads. Asiedu (2002) finds that the infrastructure development attracts FDI to non-SSA countries, but has no significant impact in SSA sample. They explain their findings by the fact that FDI to SSA tends to be natural resource based and thus non-significance of infrastructure shouldn't be surprising since infrastructure, particularly the availability of telephones is not very relevant for investments in natural resources. 
The literature also provides evidence on infrastructure and its impact on trade. Khadaroo and Seetanah (2010) find that higher infrastructure growth are associated with greater market accessibility and reduction in transportation costs. According to their findings improved transportation systems lead to reduction in that start-up costs and costs of materials and therefore increase profit maximization for foreign firms. Limao and Venables (2001) find the importance of infrastructure development on reducing total transport costs, estimating that poor infrastructure accounts for $40 \%$ of predicted transport costs for coastal countries and up to $60 \%$ for landlocked countries. Francois and Manchin (2013) examine a panel of bilateral trade, focusing on the influence of infrastructure and institutional quality on trade patterns using Poisson estimator. They show that trade depends on institutional quality and transport and communications infrastructure in both at home and partner countries. Their findings are also quantitatively significant suggesting that low income countries will trade about $74 \%$ below trade volumes taking place between high income countries due to lower quality of institutions and infrastructure. Donaldson (2018) focus on the role of transport infrastructure, particularly on the impact of railway networks on trade costs and income level in colonial India. Using a new panel of district-level data, their findings highlight important gains of transport infrastructure. Their study shows that railways not only reduce trade costs and interregional price gaps, but also improve income levels across colonial India significantly. According to their findings, extending the railroad network to the level of average district, increases real agricultural income in that district by approximately 16 percent. Using disaggregated measure of infrastructure (the quality of rail, roads, telecommunications, ports, and airports) Nordas and Piermartini (2004) find that all types of infrastructure indicators are statistically important for trade with ports having the biggest impact. Portugal-Perez and Wilson (2012) examine the effect of so called "soft" and "hard" infrastructure on the export performance of developing countries over years 2004-2007. According to their estimates infrastructure reforms do improve 
the export performance of developing countries with the marginal effects depending on income per capita. More precisely, they show that marginal effect of the transport efficiency and business environment improvement on exports appear to be decreasing in per capita income. In contrast, the impact of physical infrastructure and information and communications technology on exports found to be increasingly important the higher the income level of a country.

However, all these studies noted in this section examine the impact of physical infrastructure endowment on FDI. Up to date, there have been no studies investigating the signalling effect of infrastructure investments on FDI due to information limitations on infrastructure investment deals. Even, signalling effect in general hasn't been explored enough in FDI literature. The only one we are aware of is the study conducted by Garriga and Phillips (2014) examining the signalling effect of aid on FDI in post conflict countries in which they argue that the decision to send aid to a country signals the donors' trust of local authorities and providing information to investors which countries are trustworthy to handle international grants and commit to certain policies.

Thus, being aware of this gap in literature, this chapter looks at a different aspect of infrastructure: its signalling impact on FDI using project level data that are announced through press to global public.

\subsection{Data and Methodology}

Data on dependent variable, annual number of FDI projects in a recipient country are derived from fDi Markets database provided by Financial Times Ltd. The database tracks cross border greenfield investments since year 2003 across all sectors and countries worldwide, provides a detailed information on each FDI project categorized by industry sector, sub-sectors, business activities and industry clusters. 
Our primary independent variable, annual number of infrastructure deals are obtained from Preqin database. Preqin's infrastructure products and services offer a detailed overview of the infrastructure industry, providing information on origin and destination country of an investment deal, sector and cluster of the industry as well as investor company name. The data set start gathering information on infrastructure deals from 1990. A brief look at the data set shows that infrastructure deals have been increasing over time in developing countries (Figure 4.1).

Figure 4. 1 Number of infrastructure projects over years in developing countries. 1990-2016

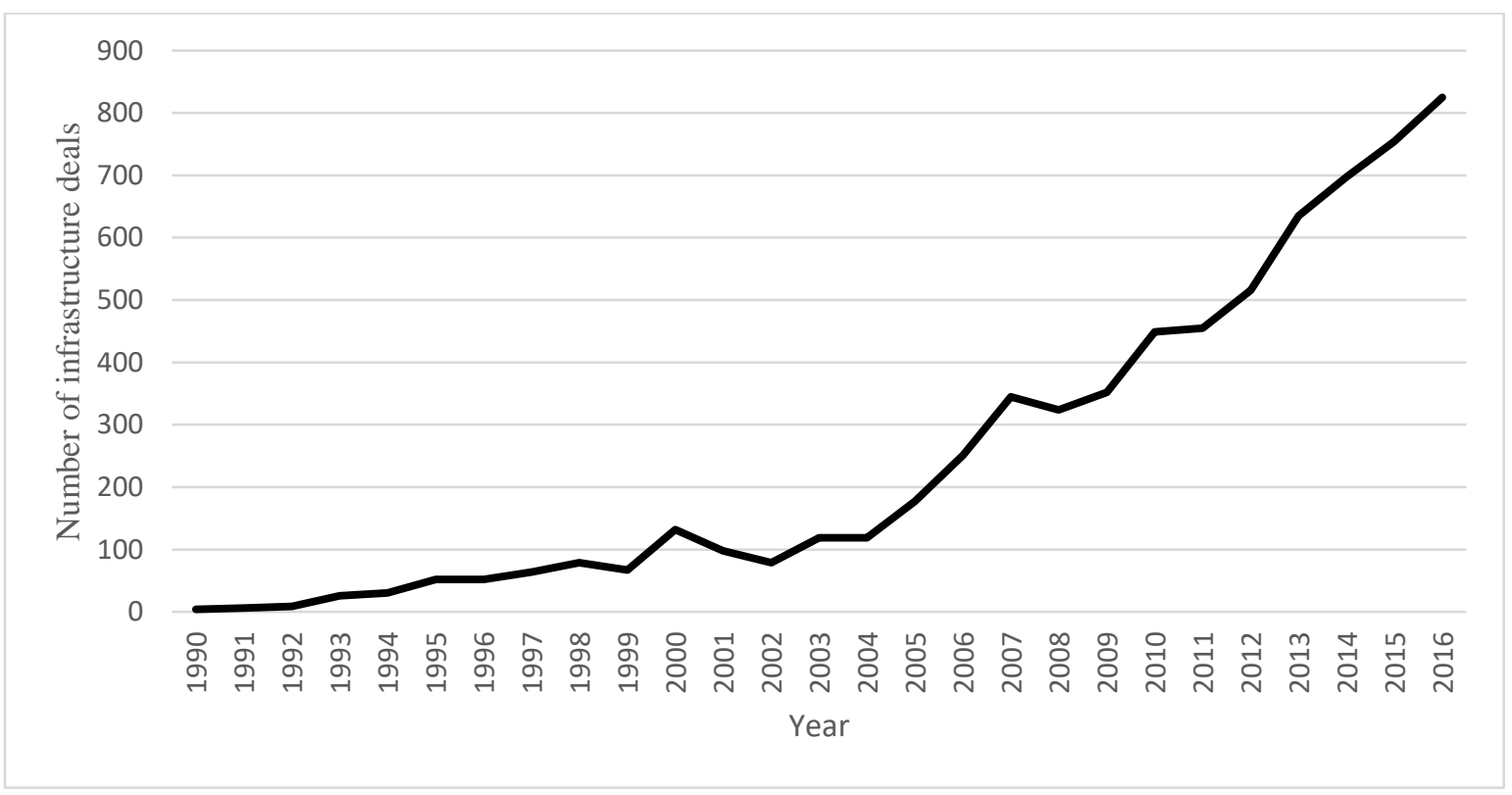

Source: Author's calculation from Preqin database.

Figure 4.2 shows that over 1990 to 2017 period, 7186 infrastructure deals have been completed in developing countries with South Asia representing the highest portion of total completed deals $(33 \%)$ in developing countries. 
Figure 4. 2 Number of infrastructure deals by region. 1990-2016

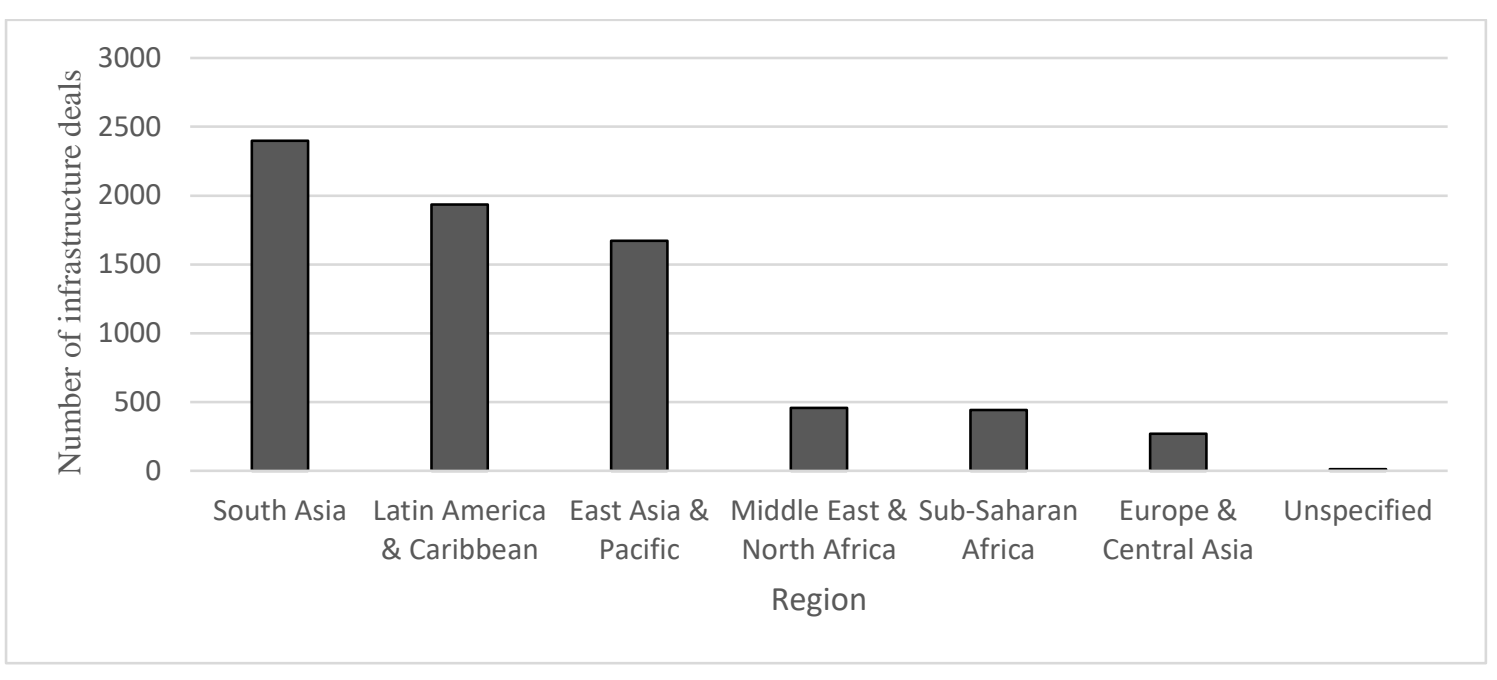

Source: Author's calculation from Preqin database.

Table 4.1 describes sectoral allocation of infrastructure projects showing that most of these deals have been allocated to energy sector $(48 \%)$ followed by transportation $(26 \%)$.

Table 4. 1 Number of infrastructure deals by sector

\begin{tabular}{lll}
\hline Sector & Number of Projects & Percentage \\
\hline Energy & 3439 & 47.9 \\
Transport & 1892 & 26.3 \\
Water \& Waste & 735 & 10.2 \\
Natural Resources & 608 & 8.5 \\
Social & 255 & 3.5 \\
ICT & 250 & 3.5 \\
Unspecified & 7 & 0.1 \\
Total & 7186 & 100.0 \\
\hline
\end{tabular}

\subsubsection{Other control variables}

Along with our main primary variable, we also control for other factors that have been associated with FDI in literature. Recipient country GDP (log GDP), GDP growth and host country income per capita (log GDP per capita) are included as a main proxy for market size, market potential and labor cost, respectively. Furthermore, we control for inflation rate as it has been associated with macroeconomic stability and future profit expectations in FDI literature. In addition, literature suggests that countries with higher government debt levels are 
perceived as highly risky by foreign investors and discourage FDI. For this reason we incorporate Debt/GDP variable into our analysis as well. All these variables are taken from World Bank, World Development Indicators. Apart from these variables, rule of law and life expectancy variables are included as an indicator of institutional quality and social development in a recipient country. These variables are derived from World Governance Indicator and World Development Indicators data sets. Table 4.2 provides summary statistics for variables used in our baseline estimation sample.

Table 4. 2 Summary statistics

\begin{tabular}{llllll}
\hline Variable & Obs & Mean & Std. Dev. & Min & Max \\
\hline FDI & 1,016 & 45.0 & 100.4 & 0.0 & 992.0 \\
Number of infra deals & 1,015 & 3.0 & 12.0 & 0.0 & 188.0 \\
GDP growth & 1,014 & 5.2 & 4.6 & -36.7 & 38.0 \\
Log GDP & 1,014 & 11.1 & 1.7 & 7.3 & 15.7 \\
Log GDP per capita & 1,014 & 8.8 & 1.2 & 6.2 & 11.8 \\
Life expectancy & 1,015 & 67.6 & 8.5 & 42.6 & 83.8 \\
Inflation rate & 1,011 & 8.1 & 35.9 & -18.1 & 1096.7 \\
Rule of law & 1,015 & 38.7 & 23.2 & 0.5 & 94.4 \\
Debt/GDP & 1,009 & 45.6 & 35.6 & 0.4 & 487.4 \\
Infrastructure quality & 791 & 3.7 & 1.1 & 1.7 & 6.7 \\
\hline
\end{tabular}

\subsubsection{Methodology}

We examine the potential signalling effect from infrastructure deals towards FDI investment using the Panel Poisson regression model. The use of Poisson regression is justifiable as the main dependent variable is the count of deals. In order to improve the consistency of the results, we first use the lagged three-year moving average of total FDI projects instead of the one-year lagged value. This may also be useful in terms of capturing the full length of the signal. Secondly, to reduce the omitted variable bias, we use other well-known determinants of FDI as control variables. We include them in our baseline model consequently to test their significance and suitability. Finally, to control for time-invariant country heterogeneity and common temporal shocks to all country, we use a two-way country and time fixed effects. 


$$
F D I_{i t}=B_{0}+B_{1} \operatorname{Infra} a_{i t-1}+B_{2} X_{i t-1}+a_{i}+\mu_{t}+\varepsilon_{i t}
$$

Where, $F D I_{i t}$ is the total number of announced FDI projects in country $i$ at time $t$; Infra $a_{i t-1}$ is the lagged total number of successfully signed infrastructure deals. It is measured by the three-year moving average from year $t-4$ to year $t-1 ; X_{i t-1}$ is the set of control variables in terms of market size, potential, human capital, political and macroeconomic stability and risk level; $a_{i}$ and $\mu_{t}$ are country and time fixed effects, respectively.

\subsection{Results}

Results are based on Poisson fixed effects estimator for years 2005-2014 for sample of developing countries. Dependent variable is total the number of FDI projects in a given year for each country. Our variable of interest, number of infrastructure projects is measured using 3-year moving average. All independent variables are lagged one year to reduce reverse causality.

\subsubsection{Baseline model}

Table 4.3, Column 1 reports estimation results for the baseline specification. Interestingly, number of infrastructure projects appears negative and highly significant. A unit increase in the number of infrastructure projects is associated with 0.06 per cent reduction in FDI. Among other control variables, only life expectancy shows to be statistically significant and implying that better life expectancy attract more FDI. Through column 2 to 4 , we include additional control variables to control for inflation rate, institutional quality (Rule of law), government debt (Debt/GDP). Results are robust to the inclusion of additional variables and show expected signs. Inflation rate appears to be negative and statistically significant suggesting that increased inflation rate reduces FDI. This could be due to the fact that higher inflation usually increase the cost of input goods and thereby reduces profitability. Rule of law is positive and highly statistically significant implying that improved institutions increases FDI. Column 4 includes 
government debt (Debt/GDP) as an additional variable to account for country risk. This variable appears to be negatively associated with FDI suggesting that higher debt is associated with higher risk by foreign investors. Finally, in the last column (column 5) we add an indicator of infrastructure quality in a host country as an additional control variable to distinguish possible endowment effects from signalling effect. ${ }^{17}$ It is possible that increasing number of infrastructure deals could capture some effects of improved physical infrastructure endowment in itself and therefore upward bias our results. Alternatively, it could be due to the fact that increasing number of infrastructure announcement deals could simple reflect lack of infrastructure endowment of a host country, i.e., poor infrastructure stock leads to new deals on infrastructure projects. Adding infrastructure quality as an additional control variable appears positive but weakly statistically significant. Our main variable of interest, the number of infrastructure projects remains both economically and statistically similar to previous results implying that negative sign of our main variable is more likely due to signalling effect rather than the endowment effect of physical infrastructure.

\footnotetext{
${ }^{17}$ We use overall infrastructure quality index from Global Competitiveness Index database of World Economic Forum to control for infrastructure endowment of a host country.
} 
Table 4. 3 Baseline model. Dependent variable: Number of FDI projects

\begin{tabular}{|c|c|c|c|c|c|}
\hline & Model 1 & Model 2 & Model 3 & Model 4 & Model 5 \\
\hline Number of infrastructure projects & $\begin{array}{l}-.00652 \\
(.00081)^{* * *}\end{array}$ & $\begin{array}{l}-.00665 \\
(.00104)^{* * *}\end{array}$ & $\begin{array}{l}-.00567 \\
(.00105)^{* * *}\end{array}$ & $\begin{array}{l}-.00560 \\
(.00097)^{* * * *}\end{array}$ & $\begin{array}{l}-.00501 \\
(.00079) * * *\end{array}$ \\
\hline GDP growth & $\begin{array}{l}.00431 \\
(.00341)\end{array}$ & $\begin{array}{l}.00558 \\
(.00356)\end{array}$ & $\begin{array}{l}.00502 \\
(.00362)\end{array}$ & $\begin{array}{l}.00521 \\
(.00376)\end{array}$ & $\begin{array}{l}.00771 \\
(.00433)^{*}\end{array}$ \\
\hline Log GDP & $\begin{array}{l}.40572 \\
(.32002)\end{array}$ & $\begin{array}{l}.37667 \\
(.31837)\end{array}$ & $\begin{array}{l}.24934 \\
(.34330)\end{array}$ & $\begin{array}{l}.26460 \\
(.31223)\end{array}$ & $\begin{array}{l}.06670 \\
(.33404)\end{array}$ \\
\hline Log GDP per capita & $\begin{array}{l}.12691 \\
(.17109)\end{array}$ & $\begin{array}{l}.19084 \\
(.51688)\end{array}$ & $\begin{array}{l}.18019 \\
(.53104)\end{array}$ & $\begin{array}{l}.00458 \\
(.46560)\end{array}$ & $\begin{array}{l}-.17696 \\
(.41194)\end{array}$ \\
\hline Life expectancy & $\begin{array}{l}.05836 \\
(.02582) * *\end{array}$ & $\begin{array}{l}.05875 \\
(.02614)^{* *}\end{array}$ & $\begin{array}{l}.04995 \\
(.02552)^{*}\end{array}$ & $\begin{array}{l}.05141 \\
(.02525) * *\end{array}$ & $\begin{array}{l}.06509 \\
(.02250) * * *\end{array}$ \\
\hline Inflation rate & & $\begin{array}{l}-.00001 \\
(.00001)^{*}\end{array}$ & $\begin{array}{l}-.00001 \\
.00001)^{* *}\end{array}$ & $\begin{array}{l}-.00001 \\
(.00001)^{* * *}\end{array}$ & $\begin{array}{l}-.00001 \\
(.00001)^{*}\end{array}$ \\
\hline Rule of law & & & $\begin{array}{l}.01789 \\
(.00631)^{* * *}\end{array}$ & $\begin{array}{l}.01677 \\
(.00641)^{* * * *}\end{array}$ & $\begin{array}{l}.01485 \\
(.00635) * *\end{array}$ \\
\hline Debt/GDP & & & & $\begin{array}{l}-.00454 \\
(.00192)^{* *}\end{array}$ & $\begin{array}{l}-.00083 \\
(.00205)\end{array}$ \\
\hline Infrastructure quality & & & & & $\begin{array}{l}.16466 \\
(.08439) * \\
\end{array}$ \\
\hline Log likelihood & -3830.340 & -3682.991 & -3612.629 & -3544.396 & -2831.214 \\
\hline Number of observations & 1065 & 1028 & 1028 & 1016 & 776 \\
\hline Number of periods & 11 & 11 & 11 & 11 & 11 \\
\hline
\end{tabular}

$* \mathrm{p}<.10, * * \mathrm{p}<.05, * * * \mathrm{p}<.01$ Note: Number of infrastructure projects is measured using lag 3 -year moving average. The other explanatory variables are measured using $1-$ year lag. Time and year fixed effects are included across all specifications. 
The channels for negative signalling in the baseline models above, we have found that the more successful private infrastructure deals in a country for the past three years, the lower the number of registered FDI projects. In other words, it appears that infrastructure investment produces a negative signal FDI firms' decision. However, in the existing literature, the host country's infrastructure quality has been widely considered as a crucial determinant for attracting FDI (Wheeler \& Mody, 1992; Mollick, Ramos-Duran, \& Silva-Ochoa, 2006). Therefore, to some certain extent, our finding seems surprising and counterintuitive. In order to explain this, we look more closely to the potential channels in which the negative signalling effect can pass through. Firstly, as Preqin collect its infrastructure dataset based on the successful bid of investors, the raw count of projects as may not be a suitable proxy for the improvement of the host country's infrastructure quality. The reason may lie upon the fact that infrastructure projects, irrespective of whether fully funded by private investors or partially funded by the government through PPP scheme, normally take long time to complete (Delmon, 2009). As a result, our main explanatory variable may insufficiently capture the FDI firms' consideration in terms of the infrastructure quality.

However, If the lengthy life were the only reason behind the failure of infrastructure projects to signal FDI investment, we would expect the estimation of our main coefficient to be insignificant but at least positive. One potential explanation is that even though any direct benefit may require a longer time to take place, FDI firms should still count an increasing amount of successfully signed infrastructure projects as a positive proxy for the host country's improvement in the business environment. In fact, as shown in the baseline models, we found the coefficient of the infrastructure variable to be negative and statistically significant at the conventional levels. In other words, throughout our period of study, the announcement of infrastructure projects not only fail to attract but even discourage FDI firms from investing. 
Therefore, it is very likely that that apart from the measurement error described above, there may be some other underlying reasons behind our surprising preliminary findings.

As infrastructure projects are normally large, costly and slow to complete, it is reasonable to expect they would contain considerably higher amount of risk compared to other types of investment (Delmon, 2009). In other words, they are highly vulnerable to volatilities in the financial market, political environment or institutional quality (Busse \& Hefeker, 2007). More importantly, host country's government usually involves in infrastructure projects, either directly by providing funds under the PPP scheme or indirectly by providing guarantee for private loans. In distressed situations, as the benefit from infrastructure projects are generally long-term, FDI investors may only look at the amount of risk embedded in these projects to the host country while making decisions. As a result, the more abundant the infrastructure projects as, the clearer the sign of a potential debt crisis or financial market crash in the host country in the near future. In other words, the riskiness of infrastructure projects may significantly contribute to the loss of trust of FDI investors in the credit stability of host country's economy. In summary, it is reasonable to expect that the negative and significant signal to be conditioned upon some underlying factors that are specific to the distressed situations. We fail to address this issue by estimating the full sample of countries and periods. In order to provide concrete supporting evidences for this hypothesis, we proceed by breaking down our sample using several criteria and exploring the heterogeneity of the results.

\subsubsection{By period}

Firstly, in order to examine the source of negative signal that may stem from the global investors' decline of trust in the financial system, we divide our full sample according to the 2007-2008 financial crisis and re-estimate the baseline model without the infrastructure quality variable. Because the financial crisis represents a period of high volatility in the global financial 
market, MNEs may see a larger amount of risk to the host country embedded in the existing infrastructure projects and become more sceptical about settling in. Overall, we expect that the negative signal would be highly significant during the crisis period. In contrast, before and after the crisis, as the global financial market is more stable, FDI investors would be more willing to overlook the high risk contained in the infrastructure projects. As a result, we presume that our main estimated coefficient would retain the positive sign that usually founded in the FDI literature. We define 2007 to be the beginning of the crisis period as we aim to identify the change in the degree of trust of FDI investors. Year 2007 marks the start of the subprime mortgage and banking crisis in the United States, which may scholars consider as the origin of the global breakdown of confidence in the financial system (Shiller, 2012).

Table 4.4 reports the result of the baseline model using the full sample of countries before and after the crisis. Intriguingly, the signalling towards FDI investment of infrastructure deals is positive and significant at 1 per cent level in column (1) but negative and significant at the same level in column (2). More specifically, ceteris paribus, one more successfully signed infrastructure project in the last three years is associated with a 3.2 per cent increase in the expected number of FDI projects before 2007, which is consistent with the existing literature of the relationship between infrastructure and FDI. In contrast, after 2007, it is instead associated with 0.3 per cent decrease in the expected number of FDI projects. As this reverse in sign perfectly matches the global financial crisis' occurrence, the global decline in FDI investors' risk appetite and trust may play an important role in defining the success of infrastructure signalling. The contribution of the specific host country's degree of trust towards the variance of the signal is controlled for, at least partially, by using debt to GDP ratio variable. Finally, by examining different ending year of the crisis, we found that the estimated coefficient turn positive and significant again after 2012, as shown in column (3). Even though the signal's magnitude -0.9 per cent increase in the expected number of FDI projects - is weaker than 
before crisis, this does provide supporting evidence for the fact that when FDI investors recover their trust after the crisis, infrastructure retains their role in signalling FDI investment. In fact, due to data limitation, we obtain this result using only two years the time dimension. Therefore, the significance and sustainability of this recovery still require more confirmation in later research.

Table 4. 4 By period. Dependent variable: Number of FDI projects

\begin{tabular}{|c|c|c|c|}
\hline & Before crisis & After crisis & After 2012 \\
\hline \multirow{2}{*}{$\begin{array}{l}\text { Number of infrastructure } \\
\text { projects }\end{array}$} & 0.03255 & -0.00300 & 0.00991 \\
\hline & $(0.005) * * *$ & $(0.001) * *$ & $(0.004) * *$ \\
\hline \multirow[t]{2}{*}{ GDP growth } & -0.00251 & 0.00719 & -0.01730 \\
\hline & $(0.009)$ & $(0.005)$ & $(0.017)$ \\
\hline \multirow[t]{2}{*}{ Log GDP } & 2.26808 & 0.30612 & -0.52814 \\
\hline & $(2.074)$ & $(0.579)$ & $(2.575)$ \\
\hline \multirow[t]{2}{*}{ Log GDP per capita } & -3.09728 & -0.29627 & 4.55243 \\
\hline & $(1.984)$ & $(0.705)$ & $(2.327) *$ \\
\hline \multirow[t]{2}{*}{ Life expectancy } & -0.09479 & 0.08088 & -0.13531 \\
\hline & $(0.095)$ & $(0.025) * * *$ & $(0.130)$ \\
\hline \multirow[t]{2}{*}{ Inflation rate } & 0.00719 & -0.00001 & -0.02519 \\
\hline & $(0.008)$ & $(0.000)$ & $(0.020)$ \\
\hline \multirow[t]{2}{*}{ Rule of law } & 0.00501 & 0.02258 & 0.00406 \\
\hline & $(0.009)$ & $(0.010) * *$ & $(0.026)$ \\
\hline \multirow[t]{2}{*}{ Debt/GDP } & -0.00626 & -0.00060 & 0.00833 \\
\hline & $(0.002) * * *$ & $(0.004)$ & $(0.017)$ \\
\hline \multirow[t]{2}{*}{ Infrastructure quality } & -0.69387 & 0.14198 & 0.14685 \\
\hline & $(8.238)$ & $(0.094)$ & $(0.270)$ \\
\hline Log likelihood & -376.469 & -2016.5225 & -240.878 \\
\hline Number of observations & 195 & 578 & 148 \\
\hline Number of periods & 3 & 8 & 2 \\
\hline
\end{tabular}

Note: Number of infrastructure projects is measured using lag 3-year moving average. The other explanatory variables are measured using 1-year lag. Time and year fixed effect are included across all specifications. 


\subsubsection{By host country's debt to GDP}

In this section, we look more closely towards the distressed situations that emerges from host country's specific risk level. In order to do so, we compute the period-average debt to GDP ratio - a proxy for government's default risk - for each country and then divide them into two groups: countries with ratio below and above the median level. We label the former group as the low-risk host country and the latter group as the high-risk host country. Interestingly, the estimation of the main coefficient is only positive and significant for the low-risk group while it is negative and significant for the other, as shown in column (1) and (2) of Table 4.5. While one more successfully signed infrastructure deal induces 2.1 per cent increase in the expected number of FDI projects in the first group, it reduces the number by 0.5 per cent in the second. In other words, whether infrastructure investment is capable of signalling FDI investment highly depends on the host country's current risk level. In heavily indebted countries, the abundance of recent infrastructure projects may associate with a high possibility of government default and economic instability in the near future and thus discourage MNEs. This is consistent with Hurley et al., (2018)'s findings in which some countries, mainly heavily indebted, have significantly increased their sovereign debt after receiving infrastructure funding according to the "Belt and Road Initiative" (BRI) ${ }^{1}$ by the Chinese government. In contrast, in countries with lower levels of debt, FDI investors would have a higher trust on the governments' abilities to withstand any fluctuation or shock that may happen. Therefore, they may see lower amount of risk embedded in current infrastructure projects and more likely to neglect it while making investment decisions.

\footnotetext{
${ }^{1}$ Formerly known as the One Belt One Road Initiative
} 
Table 4. 5 By host country's debt/GDP (Quantile by Debt/GDP). Dependent variable: Number of FDI projects

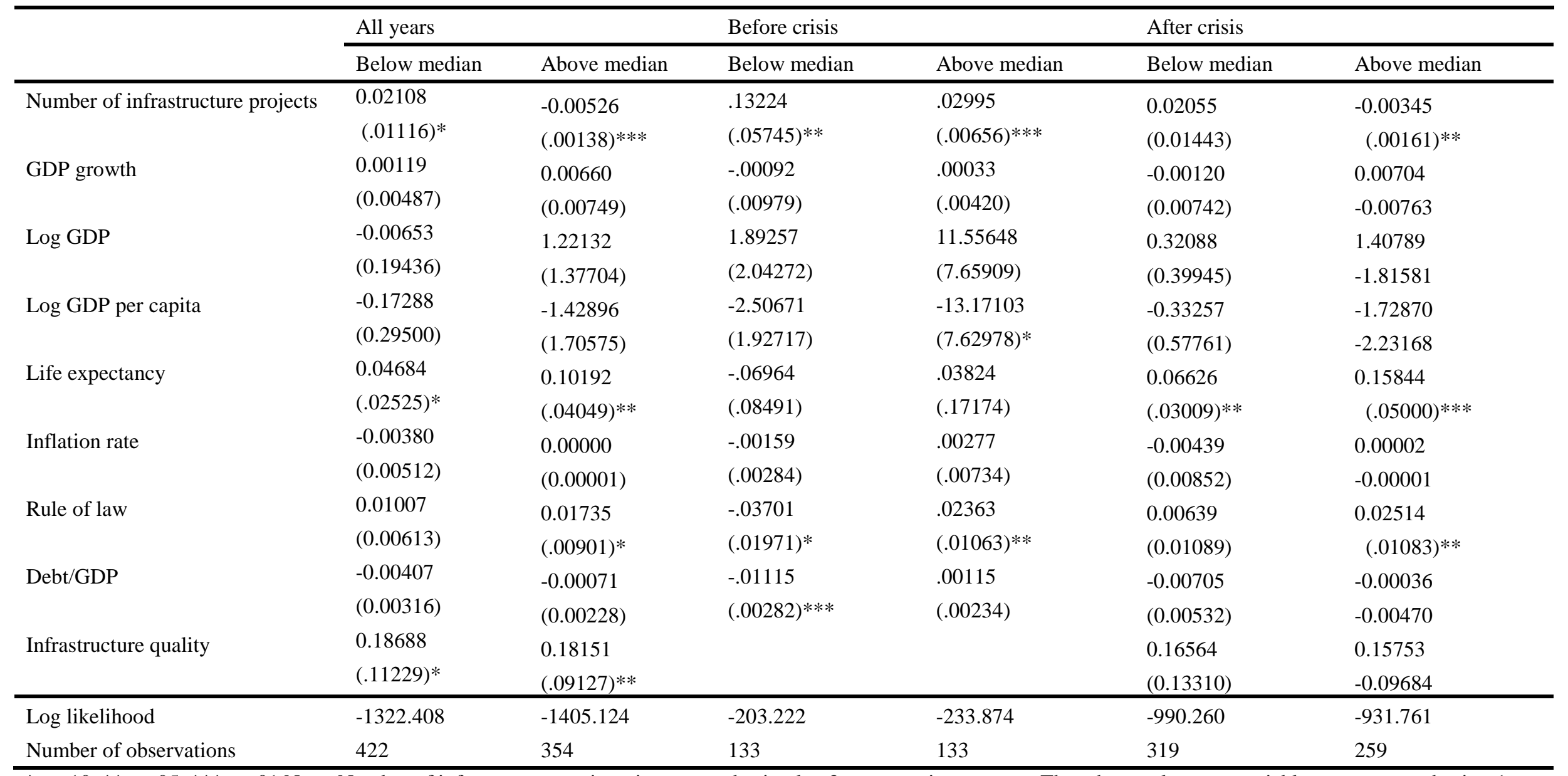

$* \mathrm{p}<.10, * * \mathrm{p}<.05, * * * \mathrm{p}<.01$ Note: Number of infrastructure projects is measured using lag 3-year moving average. The other explanatory variables are measured using 1 year lag. Time and year fixed effect are included across all specifications. 
We also investigate two groups of countries before and after the crisis in order to test whether incorporating host country's risk level in this section contaminate our conclusion on the effect of the global risk aversion in the previous section. On the one hand, as shown in column (3) and (4), when the global investors were more willing to tolerate risk, we found positive signalling effect in both low-risk and high-risk countries. ${ }^{1}$ On the other hand, after the crisis, only infrastructure projects in former are capable of attracting FDI investment while those in latter even discourage FDI investment. In other words, within each group, the decline in the global risk tolerance did reduce the signal strength, which is consistent with the previous section. However, in terms of the magnitude, the signal reduces by 84.8 per cent in the lowrisk group and 111 per cent in the high-risk group. In other words, the impact is asymmetric and more adverse towards the high-risk countries. Therefore, it is reasonable to conclude that both the global risk appetite and the specific host country's sovereign debt risk are responsible for the degree of risk that FDI investors place on existing infrastructure projects and consequently the signal strength.

\subsubsection{Developed and developing countries}

In the last section's conclusion, questions remain whether the debt to GDP ratio is sufficient to capture the host country's risk level. In order to address this issue, we expand our sample to compare developing and developed countries in terms of infrastructure signalling. We interpret the results in Table 4.6 based on the natural assumption that FDI investors may view the latter group as less risky. As shown in the first two columns, during the period of study, the signal is

\footnotetext{
${ }^{1}$ Note that we do not include "infrastructure quality" variable on column 3 and column 4 . This is because we have a very small sample for this sub-group of countries and adding infrastructure quality variable in the estimation results makes our sample even smaller due to missing values of this variable and Maximum Likelihood Estimation (MLE) do not converge.
} 
positive and highly significant in developed countries. On average, one more infrastructure projects in developed countries in the last three year is associated with 0.1 per cent increase in the expected number of FDI project, compared to a decrease of 0.5 per cent as we have found for developing countries in the baseline model. Gathering countries altogether and adding the interaction between infrastructure and log GDP per capita produces a similar conclusion, as shown in column (3). The overall signal is negative and significant, largely due to the dominance of developing countries in the full sample. However, interestingly, 1 per cent increase in GDP per capita increase the signal by 0.2 per cent. If development level is a suitable proxy for risk level, then these results provide further evidences on the role of host country's risk level in the success of infrastructure signal. 
Table 4. 6 Developed and developing countries. Dependent variable: Number of FDI projects

\begin{tabular}{|c|c|c|c|c|c|c|c|}
\hline \multirow{2}{*}{ Countries } & \multicolumn{3}{|c|}{ All years } & \multicolumn{2}{|c|}{ Before crisis } & \multicolumn{2}{|c|}{ After crisis } \\
\hline & Developing & Developed & All & Developing & Developed & Developing & Developed \\
\hline $\begin{array}{l}\text { Number of infrastructure } \\
\text { projects }\end{array}$ & $\begin{array}{l}-0.00501 \\
(.00079) * * *\end{array}$ & $\begin{array}{l}0.00174 \\
(.00058)^{* * * *}\end{array}$ & $\begin{array}{l}-0.02001 \\
(.00389)^{* * *}\end{array}$ & $\begin{array}{l}0.03256 \\
(.00459)^{* * *}\end{array}$ & $\begin{array}{l}0.00197 \\
(0.00217)\end{array}$ & $\begin{array}{l}-0.003 \\
(.00120)^{* *}\end{array}$ & $\begin{array}{l}0.00129 \\
(.00053)^{* *}\end{array}$ \\
\hline GDP growth & $\begin{array}{l}0.00771 \\
(.00433)^{*}\end{array}$ & $\begin{array}{l}0.02084 \\
(.01027)^{* *}\end{array}$ & $\begin{array}{l}0.02125 \\
(.00501)^{* * * *}\end{array}$ & $\begin{array}{l}-0.00251 \\
(0.00876)\end{array}$ & $\begin{array}{l}0.00092 \\
(0.01884)\end{array}$ & $\begin{array}{l}0.00719 \\
(0.00512)\end{array}$ & $\begin{array}{l}0.01166 \\
(0.00809)\end{array}$ \\
\hline Log GDP & $\begin{array}{l}0.0667 \\
(0.33404)\end{array}$ & $\begin{array}{l}2.22309 \\
(2.58063)\end{array}$ & $\begin{array}{l}1.66136 \\
(.89416)^{*}\end{array}$ & $\begin{array}{l}2.26808 \\
(2.07446)\end{array}$ & $\begin{array}{l}-10.22608 \\
(4.41344) * *\end{array}$ & $\begin{array}{l}0.30612 \\
(0.57911)\end{array}$ & $\begin{array}{l}1.6729 \\
(2.3629)\end{array}$ \\
\hline Log GDP per capita & $\begin{array}{l}-0.17696 \\
(0.41194)\end{array}$ & $\begin{array}{l}-2.71136 \\
(2.16619)\end{array}$ & $\begin{array}{l}-2.44269 \\
(.77976)^{* * * *}\end{array}$ & $\begin{array}{l}-3.09728 \\
(1.98376)\end{array}$ & $\begin{array}{l}8.90115 \\
(4.18518)^{* *}\end{array}$ & $\begin{array}{l}-0.29627 \\
(0.7053)\end{array}$ & $\begin{array}{l}-2.56503 \\
(2.19248)\end{array}$ \\
\hline Life expectancy & $\begin{array}{l}0.06509 \\
(.02250)^{* * *}\end{array}$ & $\begin{array}{l}-0.00283 \\
(0.06182)\end{array}$ & $\begin{array}{l}0.01706 \\
(0.02948)\end{array}$ & $\begin{array}{l}-0.09479 \\
(0.09506)\end{array}$ & $\begin{array}{l}0.19717 \\
(0.2116)\end{array}$ & $\begin{array}{l}0.08088 \\
(.02521)^{* * *}\end{array}$ & $\begin{array}{l}-0.05735 \\
(0.0676)\end{array}$ \\
\hline Inflation rate & $\begin{array}{l}-0.00001 \\
(.00001)^{*}\end{array}$ & $\begin{array}{l}0.00212 \\
(0.0103)\end{array}$ & $\begin{array}{l}-0.00001 \\
(0.00001)\end{array}$ & $\begin{array}{l}0.00719 \\
(0.00818)\end{array}$ & $\begin{array}{l}-0.00261 \\
(0.01262)\end{array}$ & $\begin{array}{l}-0.00001 \\
(0.00001)\end{array}$ & $\begin{array}{l}0.00947 \\
(0.01172)\end{array}$ \\
\hline Rule of law & $\begin{array}{l}0.01485 \\
(.00635)^{* *}\end{array}$ & $\begin{array}{l}0.00193 \\
(0.00784)\end{array}$ & $\begin{array}{l}0.00808 \\
(0.00739)\end{array}$ & $\begin{array}{l}0.00501 \\
(0.00854)\end{array}$ & $\begin{array}{l}0.00617 \\
(0.01242)\end{array}$ & $\begin{array}{l}0.02258 \\
(.00984) * *\end{array}$ & $\begin{array}{l}0.01014 \\
(0.00793)\end{array}$ \\
\hline Debt/GDP & $\begin{array}{l}-0.00083 \\
(0.00205)\end{array}$ & $\begin{array}{l}0.00153 \\
(0.00328)\end{array}$ & $\begin{array}{l}-0.00384 \\
(.00225)^{*}\end{array}$ & $\begin{array}{l}-0.00626 \\
(.00227)^{* * *}\end{array}$ & $\begin{array}{l}-0.00951 \\
(0.00785)\end{array}$ & $\begin{array}{l}-0.0006 \\
(0.00403)\end{array}$ & $\begin{array}{l}0.00179 \\
(0.00352)\end{array}$ \\
\hline Infrastructure quality & $\begin{array}{l}0.16466 \\
(.08439)^{*}\end{array}$ & $\begin{array}{l}-0.2535 \\
(.10373) * *\end{array}$ & $\begin{array}{l}-0.03247 \\
(0.07197)\end{array}$ & $\begin{array}{l}-0.69387 \\
(8.23638)\end{array}$ & $\begin{array}{l}20.14755 \\
(3.38591) * * *\end{array}$ & $\begin{array}{l}0.14198 \\
(0.09373)\end{array}$ & $\begin{array}{l}-0.20462 \\
(.09303) * *\end{array}$ \\
\hline $\begin{array}{l}\text { Infrastructure x Log GDP pe } \\
\text { capita }\end{array}$ & & & $\begin{array}{l}0.00206 \\
(.00037)^{* * *}\end{array}$ & & & & \\
\hline Log likelihood & -2831.214 & -2771.861 & -6200.758 & -376.469 & -374.708 & -2016.523 & -1666.543 \\
\hline Number of observations & 776 & 439 & 1215 & 195 & 116 & 578 & 323 \\
\hline
\end{tabular}

$* \mathrm{p}<.10, * * \mathrm{p}<.05, * * * \mathrm{p}<.01 \quad$ Note: Number of infrastructure projects is measured using lag 3 -year moving average. The other explanatory variables are measured using 1 year lag. Time and year fixed effect are included across all specifications 
Looking at two group of countries - developing and developed - before and after the 20072008 financial crisis, we found very similar results to the previous section. More specifically, the lower the development level, the more severe the crisis' negative impact. After crisis, having signed more infrastructure deals even discourage FDI investment in the former group due to the corresponding risk level.

\subsection{Conclusion}

Using project level data set of announced infrastructure investment deals this study examined the role of infrastructure as a signalling to foreign investors. We found that infrastructure deals are negatively associated with FDI in developing countries. In order to explain the reasoning behind the findings, we look more closely to the potential channels in which the negative signalling effect can pass through. First, we split our sample pre-crisis, during crisis and after crisis period to see if the source of negative signal partially stems from the global investors' decline of trust in the financial system. Results mainly support our hypothesis, suggesting that signalling towards FDI investment of infrastructure deals is positive and significant during precrisis and post-crisis period, but negative and significant during the crisis period. Furthermore, to understand the main source of negative signalling effect of infrastructure deals, we look more closely at the country specific risk level arising from fiscal distress of host country. Results suggests that signalling is positive and significant for the low-risk group while it is negative and highly significant for the high risk group countries. In other words, whether infrastructure investment has a positive signalling effect on FDI highly depends on the host country's current risk level. While in countries with low risk level, infrastructure deals retains their role in signalling FDI, in heavily indebted countries, the abundance of recent infrastructure projects may have been associated with a high possibility of government default and economic instability in the near future and thus discourage multinational firms. 


\section{References:}

Aizenman, J., Jinjarak, Y., \& Zheng, H. (2018). Chinese outwards mercantilism - The art and practice of bundling. Journal of International Money and Finance, 86, 31-49.

Amaya, C. A., \& Rowland, P. (2004). Determinants of Investment Flows into Emerging Markets. Banco de la República.

Amighini, A., Rabellotti, R., \& Sanfilippo, M. (2013). China's outward FDI: An industrylevel analysis of host-country determinants. Frontiers of Economics in China, 8(3), 309-336.

Arnold, M. (2017, June 27). European banks to launch blockchain trade finance platform Seven lenders hire IBM to build technology for SMEs to finance cross-border orders. Financial Times.

Asiedu, E. (2002). On the determinants of foreign direct investment to developing countries: is Africa different? . World development, 30(1), 107-119.

Barth, J. R., Lin, C., Lin, P., \& Song, F. M. (2009). Corruption in bank lending to firms: Cross-country micro evidence on the beneficial role of competition and information sharing. . Journal of Financial Economics, 91(3), 361-388.

Beck, T., Demirgüç-Kunt, A., \& Singer, D. (2013). Is small beautiful? Financial structure, size and access to finance. World Development, 52, 19-33.

Beck, T., Klapper, L. F., \& Mendoza, J. C. (2010). The typology of partial credit guarantee funds around the world. Journal of Financial Stability, 6, 10-25.

Berger, A. N., \& Udell, G. F. (2006). A more complete conceptual framework for SME finance. Journal of Banking \& Finance, 30(11), 2945-2966.

Bhaumik, S. K., \& Co, C. Y. (2011). China's economic cooperation related investment: An investigation of its direction and some implications for outward investment. China Economic Review, 22(1), 75-87.

BIS, S. (2012). Access to External Finance in BIS Economics Papers. BIS, Editor.

Böttcher, B. (2013). Making a difference: German SMEs and their financing environment. Deutsche Bank.

Buckley, P. J., Clegg, L. J., Cross, A. R., Liu, X., Voss, H., \& Zheng, P. (2009). The determinants of Chinese outward foreign direct investment. Journal of International Business Studies, 38(4), 499-518.

Burger, M., Van Oort, F., \& Linders, G. J. (2009). On the specification of the gravity model of trade: zeros, excess zeros and zero-inflated estimation. Spatial Economic Analysis, 4(2), 167-190. 
Busse, M., \& Hefeker, C. (2007). Political risk, institutions and foreign direct investment. European journal of political economy, 23(2), 397-415.

Cheng, L. K., \& Ma, Z. (2010). China's outward foreign direct investment. In China's growing role in world trade. University of Chicago Press, 545-578.

Cheung, Y., \& Qian, X. (2009). Pacific Economic Review, 14(3), 312-341.

de la Torre, A., Pería, M. S., \& Schmukler, S. L. (2010). Bank Involvement with SMEs:Beyond Relationship Lending. Journal of Banking \& Finance, 34, 2280-2293.

Delmon, J. (2009). Private sector investment in infrastructure: Project finance, PPP projects and risks. Kluwer Law International.

Deng, P. (2004). Outward investment by Chinese MNCs: Motivations and implications. Business horizons, 47(3), 8-16.

Donaldson, D. (2018). Railroads of the Raj: Estimating the impact of transportation infrastructure. American Economic Review, 108(4-5), 899-934 .

Dunning, J. (1977). Trade, location of economic activity and the MNE: A search for an eclectic approach. In The international allocation of economic activity. London: Palgrave Macmillan.

Etienne, Y., Hammami, M., \& Ruhashyankiko, J.-F. (2006). Determinants of public-private partnerships in infrastructure (No. 6-99). International Monetary Fund.

Flowerdew, R., \& Aitkin, M. (1982). A method of fitting the gravity model based on the Poisson distribution. Journal of regional science, 22(2), 191-202.

Francois, J., \& Manchin, M. (2007). Institutions, infrastructure, and trade. The World Bank.

Garriga, A. C., \& Phillips, B. J. (2014). Foreign aid as a signal to investors: Predicting FDI in post-conflict countries. Journal of Conflict Resolution, 58(2), 280-306.

H., D. J. (1977). Trade, location of economic activity and the MNE: A search for an eclectic approach. In The international allocation of economic activity. London: Palgrave Macmillan.

Harvie, C. (2010). Small and Medium Enterprises' Access to Finance: Evidence from Selected Asian Economies. International Journal of Business and Development Studies , 27-62.

Harvie, C., Narjoko, D., \& Oum, S. (2013). Small and Medium Enterprises’ Access to Finance: Evidence from Selected Asian Economies. ERIA Discussion Paper Series, ERIA-DP-2013-23.

Heckman, J. J. (1979). Sample selection bias as a specification error. Econometrica, v47(1), 153-162. 
Helpman, E., Melitz, M., \& Rubinstein, Y. (2008). Estimating trade flows: Trading partners and trading volumes. . The quarterly journal of economics, 123(2), 441-487.

Holland, D., \& Pain, N. (1998). The diffusion of innovations in Central and Eastern Europe: A study of the determinants and impact of foreign direct investment. London: National Institute of Economic and Social Research.

Hurley, J., Morris, S., \& Portelance, G. (2018, March). Examining the Debt Implications of the Belt and Road Initiative from a Policy Perspective. Center for global Development.

Jinjarak, Y., \& Wignaraja, G. (2016). An Empirical Assessment of the Export-Financial Constraint Relationship: How Different are Small and Medium Enterprises? World Development, 79, 152-163.

Khadaroo, A. J., \& Seetanah, B. (2010). Transport infrastructure and foreign direct investment. . Journal of International Development: The Journal of the Development Studies Association, 22(1), 103-123.

Kirkpatrick, C., Parker, D., \& Zhang, Y.-F. (2006). Foreign direct investment in infrastructure in developing countries: does regulation make a difference? Transnational Corporations, 15(1), 143.

Kolstad, I., \& Wiig, A. (2012). What determines Chinese outward FDI? Journal of World Business, 47(1), 26-34.

Konijn, P. (2014). Chinese Resources-for-Infrastructure (R4I) Swaps: An Escape from the Resource Curse. South African Institute of International Affairs. Retrieved from https://www.africaportal.org/publications/chinese-resources-for-infrastructure-r4iswaps-an-escape-from-the-resource-curse/

Lecraw, D. J. (1993). Outward Direct Investment by Indonesian Firms: Motivation and Effects. Journal of International Business Studies, 24(3), 589-600.

Linders, G. J., \& De Groot, H. (2006). Estimation of the gravity equation in the presence of zero flows. Working paper.

MOFCOM. (2014). Statistical Bulletin of China's Outward Foreign Direct Investment. Beijing: Ministry of Foreign Commerce.

Mollick, A. V., Ramos-Duran, R., \& Silva-Ochoa, E. (2006). Infrastructure and FDI inflows into Mexico: A panel data approach. Global Economy Journal, 6(1).

Morck, R., Yeung, B., \& Zhao, M. (2008). Perspectives on China's outward foreign direct investment. Journal of International Business Studies, 39(3), 337-350.

Neumayer, E., \& Spess, L. (2005). Do bilateral investment treaties increase foreign direct investment to developing countries? World Development, 33(10), 1567-1585. 
Nichter, S., \& Goldmark, L. (2009). Small firm growth in developing countries. World Development, 37(9), 1453-1464.

Nordås, H. K., \& Piermartini, R. (2004). Infrastructure and Trade . WTO Staff Working Paper, ERSD-2004-04 .

OECD. (2014). FDI in Figures. OECD.

OECD. (2015). Fosterinf Investment in Infrastructure. OECD.

Ono, A., \& Uesugi, I. (2009). Role of Collateral and Personal Guarantees in Relationship Lending: Evidence from Japan's SME Loan Market. Journal of Money, Credit and Banking, 41(5), 935-960.

Pansiri, J., \& Temtime, Z. T. (2010). Linking firm and managers' characteristics to perceived critical success factors for innovative entrepreneurial support. Journal of Small Business and Enterprise Development, 17(1), 45-59.

Peter J Buckley, L. J. (n.d.). The Determinants of Chinese Outward Foreign Direct Investment.

Portugal-Perez, A., \& Wilson, J. S. (2012). Export performance and trade facilitation reform: Hard and soft infrastructure. World development, 40(7), 1295-1307.

Quer, D., Claver, E., \& Rienda, L. (2012). Political risk, cultural distance, and outward foreign direct investment: Empirical evidence from large Chinese firms. Asia Pacific Journal of Management, 1089-1104.

Ramasamy, B., Yeung, M., \& Laforet, S. (2012). China's outward foreign direct investment: Location choice and firm ownership. Journal of World Business, 47(1), 17-25.

Rasiah, R., \& Thangiah, G. ( 2017). Government policies, regional trading agreements and the economic performance of local electronics component producing SMEs in Malaysia. Journal of Southeast Asian Economies (JSEAE), 34(2), 302-321.

Sader, F. (1999). Attracting foreign direct investment into infrastructure: Why is it so difficult? The World Bank.

Sanfilippo, M. (2010). Chinese FDI to Africa: What Is the Nexus with Foreign Economic Cooperation? African Development Review, 22, 599-614.

Sekkat, K., \& Varoudakis, M.-A. V. (2007). Openness, investment climate, and FDI in developing countries. Review of Development Economics, 11(4), 607-620.

Shen, Y., Shen, M., Xu, Z., \& Bai, Y. (2009). Bank Size and Small- and Medium-sized Enterprise (SME) Lending: Evidence from China. World development, 37(4), 800811. 
Shiller, R. J. (2012). The subprime solution: how today's global financial crisis happened, and what to do about it. Princeton University Press.

Silva, J. S., \& Tenreyro, S. (2006). The log of gravity. The Review of Economics and statistics, 88(4), 641-658.

Silva, J. S., \& Tenreyro, S. (2011). Further simulation evidence on the performance of the Poisson pseudo-maximum likelihood estimator. Economics Letters, 112(2), 220-222.

Stein, P., Ardic, O. P., \& Hommes, M. (2013). Closing the Credit Gap for Formal and Informal Micro, Small, and Medium Enterprises. Washington DC: International Finance Corporation.

Stiglitz, J. E., \& Weiss, A. (1992). Asymmetric information in credit markets and its implications for macro-economics. Oxford Economic Papers, 44(4), 694-724.

The Economic Times. (2013). SMEs employ close to 40\% of India's workforce, but contribute only $17 \%$ to GDP.

The Economist. (2016, June 02). SMEs in developing countries Caught in the middle.

Tinbergen, J. (1962). An analysis of world trade flows. Shaping the world economy, 3, 1-117.

Trevor, H., Robert, T., \& J. H., F. (2009). The elements of statistical learning : data mining, inference, and prediction. Springer Series in Statistics.

UNCTAD. (2015). WORLD INVESTMENT REPORT.

Venables, A., \& Limao, N. (1999). Transport infrastructure and foreign direct investment. The World Bank.

Wheeler, D., \& Mody, A. (1992). International investment location decisions: The case of US firms. Journal of international economics, 33(1-2), 57-76.

World Economic Forum. (2010). Positive Infrastructure: A Framework For Revitalizing The Global Economy.

Wu, F., \& Sia, Y. H. (2002). China's Rising Investment in Southeast Asia: Trends and Outlook. Journal of Asian Business, 18(2), 41-62.

Yoshino, N. (2013). The Background of Hometown Investment Trust Funds. In In Hometown Investment Trust Funds (pp. 1-13). Tokyo: Springer. 